\title{
STRATIGRAPHY OF QUATERNARY DUNES BY SAND MINERALOGY AND PEDOGENIC FEATURES, LOS OSOS, CALIFORNIA
}

\author{
A Thesis \\ presented to \\ the Faculty of California Polytechnic State University, \\ San Luis Obispo
}

\author{
In Partial Fulfillment \\ of the Requirements for the Degree \\ Master of Science in Agriculture, Specialization in Soil Science
}

by

Lyssa A. Cousineau

June 2012 
(C) 2012

Lyssa Anne Cousineau

ALL RIGHTS RESERVED 


\section{COMMITTEE MEMBERSHIP}

TITLE:

Stratigraphy of Quaternary Dunes by Sand Mineralogy and Pedogenic Features, Los Osos, California

AUTHOR: $\quad$ Lyssa A. Cousineau

DATE SUBMITTED: June 2012

COMMITEE CHAIR: $\quad$ Dr. Lynn E. Moody, Professor of Natural Resources Management and Environmental Sciences

COMMITTEE MEMBER: Dr. Antonio F. Garcia, Professor of Geology in the Physics Department

COMMITTEE MEMBER: $\quad$ Dr. William L. Preston, Professor of Geography 


\begin{abstract}
Stratigraphy of Quaternary Dunes by Sand Mineralogy and Pedogenic Features, Los

Osos, California

Lyssa A. Cousineau
\end{abstract}

The goal of this study was to assess mineralogy and pedogenic features of sand dunes in a stratigraphic sequence. The purpose was to determine whether these features significantly differ to reflect age differences with depth within the sequence. This study was conducted in Montaña de Oro State Park, located on the central Californian coast eighteen kilometers northwest of San Luis Obispo in San Luis Obispo County.

Samples were collected from the vertical exposure of one dune face by stratified random sampling at 1.0-m vertical intervals. Particle size distribution was determined through particle-size analysis by hydrometer and sieve. Electrical conductivity and $\mathrm{pH}$ were determined using a 1:1 soil/water paste. Total soil carbon and nitrogen contents were determined by combustion. Pedogenic iron oxides were extracted by ammonium oxalate in the dark and citrate-bicarbonate-dithionite, and then quantified by flame atomic absorption spectrometry. Sand mineralogy of fifteen thin sections was analyzed by polarized light microscopy. Grain counts quantified the sand mineralogy of the thin sections.

Total carbon significantly decreases with soil depth and age reflecting modern development of soil at 0 to 1 meters within the stratigraphic sequence. Certain morphologic and mineralogic features, including an increase in nitrogen content and the presence of fossilized fungal hyphae, suggest that a buried A horizon may be preserved 9 to 10 meters below the crest of the modern dune complex. Using relative dates compiled from previous research, it was determined that the soil at 9 to 10 meters depth was developed 15-ka to 30-ka after sand deposition during a eustatic sea level lowstand. The presence of fossils in general suggests that the ancient soil was rapidly covered. 


\section{ACKNOWLEDGEMENTS}

There are so many individuals to thank for this accomplishment, I cannot mention them all. Therefore, I provide this broad (and sincere!) statement. To my colleagues from the Natural Resources Management and Environmental Sciences Department as well as my family and friends spread throughout North America, thank you for teaching me, encouraging me, and allowing me to laugh at myself when the going got rough.

I extend sincerest gratitude to my committee chair, Dr. Lynn Moody. Thank you for your wisdom, guidance and continual support. You are an inspiration and a joy to be around, Lynn, and I would not have grown by leaps and bounds in two years without your counsel. You will be missed in the soils profession when you retire this year. I would also like to thank my graduate committee, Dr. William Preston and Dr. Antonio Garcia. Thank you for your manuscript edits, insights, and humor inside and outside of committee meetings.

Laboratory assistance was absolutely essential to my research. Technician Craig Stubler, your expertise was invaluable to my laboratory procedures and analysis. Thank you for your dedication in helping me with my thesis. You went above and beyond what I asked for, and without hesitation. All departments should be so blessed to have a technician such as you. Adrian Gallo and Scott Pensky, my undergraduate research assistants, thank you for your long hours in the lab. You kept the lab lively when I needed it most, and provided me with a fresh outlook on my research. Thomas Witman, Craig's lab assistant, surprised me by volunteering his time in the lab working on my project. Without you guys, I would not have finished in such a timely manner. I hope this experience has been as great a learning tool for you as it has been for me. I look forward to hearing about your adventures in soil science when you begin your careers in the near future.

Dr. Tryg Lundquist, from the Civil and Environmental Engineering Department at Cal Poly San Luis Obispo, thank you for letting me use your centrifuge for sample preparation. We ended up completely wearing out a relay on your thirty-year-old machine, and I had to completely redesign my procedure because the centrifuge is now unavailable indefinitely. Whoops.

National Petrographic Service, Inc. prepared thin sections with a partial grant from the Natural Resources Management and Environmental Sciences Department at Cal Poly San Luis Obispo. To Lisa Wallravin, Melanie Gutierrez and Becky Powell: You work tirelessly behind-the-scenes to make sure all the coursework, paperwork, and formatting is correct. Without your dedication and hard work, none of the Master's students would ever make it out of Cal Poly!

Jacqueline Tilligkeit, Dr. Thomas J. Rice, Lynette Niebrugge, Leslie Wilson, Shelby Delfino, and Brittany Piarulli, thanks for all of your encouragement and support in completing this thesis. I am particularly grateful to Donovan Hall, who not only assisted me with sample collection, but also was my chauffer, encouragement, chef, best friend, shoulder to cry on, and (amazingly) my occasional lab assistant. When I started this thesis, I had yet to meet you; now I cannot imagine my life without you.

Last but not least, I would like to thank my parents and the Lord; without you, I would have never made it this far. 


\section{TABLE OF CONTENTS}

Page

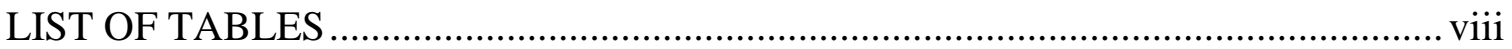

LIST OF FIGURES ……………………………….............................................. ix

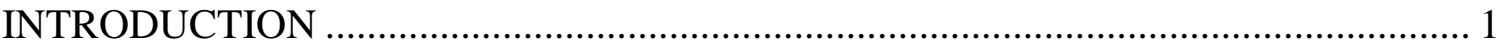

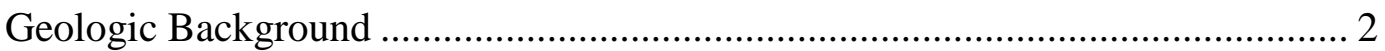

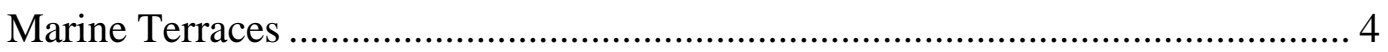

Relative Ages ........................................................................................ 5

Basal Dune Chronology ............................................................................ 6

Sand Dune Development ............................................................................... 7

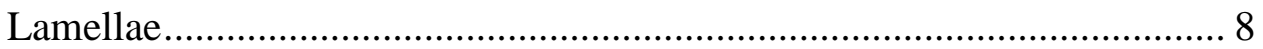

Anthropogenic Activity ............................................................................... 9

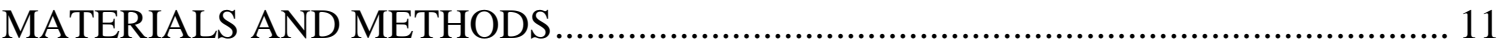

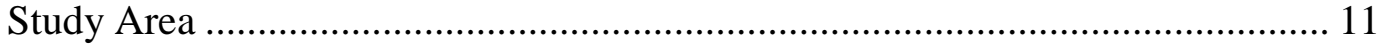

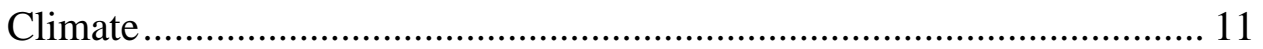

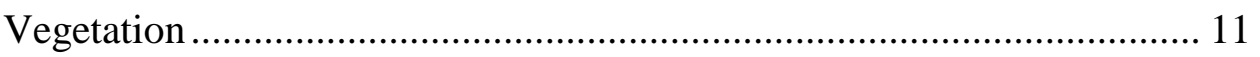

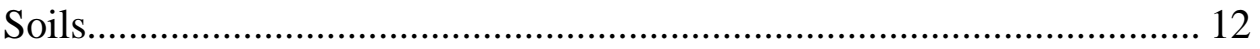

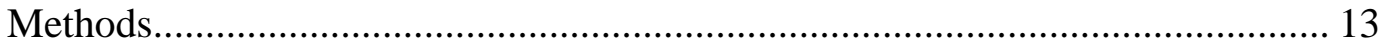

Sample Collection.................................................................................. 13

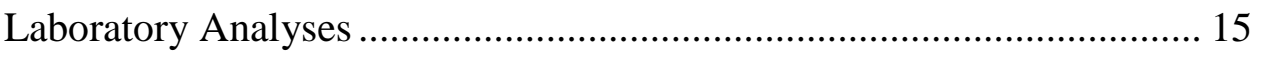




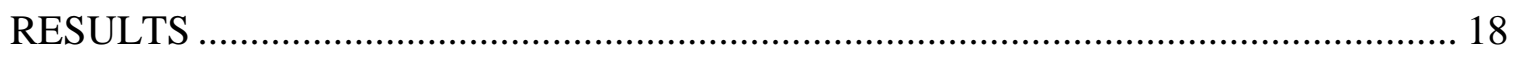

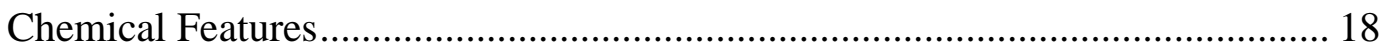

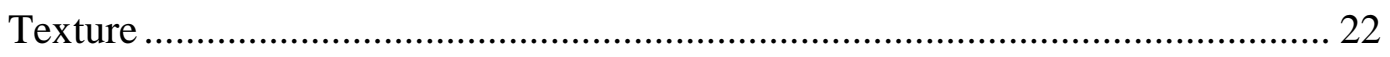

Particle Size Distribution ............................................................... 22

Roundness and Sorting ............................................................ 24

Mineralogy and Micromorphology ............................................................... 25

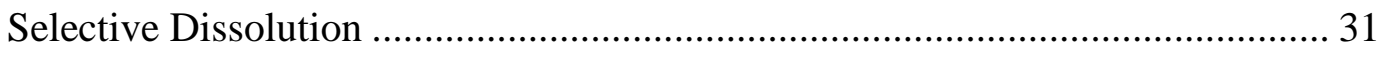

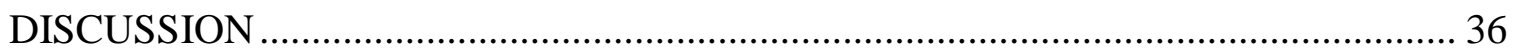

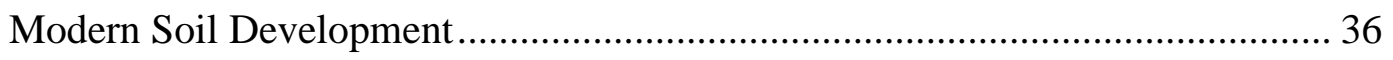

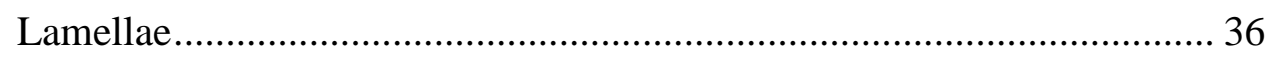

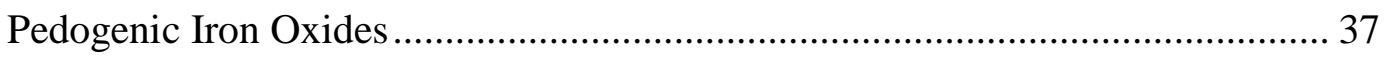

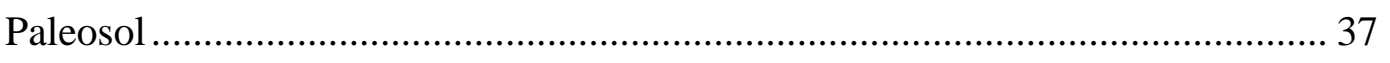

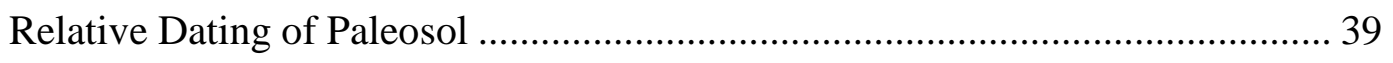

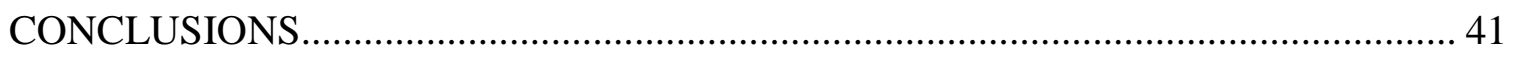

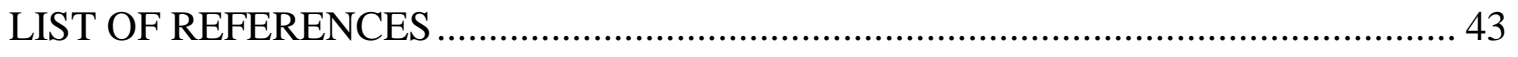

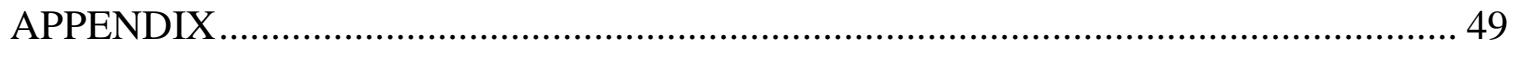

A. Table of Results for Regression Analyses ....................................... 50

B. Plates of Thin Section Features ....................................................... 53 


\section{LIST OF TABLES}

Page

Table 1-1. The four major coastal dune phases of stabilization and their maximum ages in the Morro Dune Complex (Orme, 1990)..........................................

Table 3-1. Selected chemical features of stratigraphic sequence. ................................19

Table 3-2. Particle size distribution of sand grains....................................................23

Table 3-3. Prominent sorting and roundness of sand grains. Roundness not determined at 5 to 6 meters because thin sections were not produced

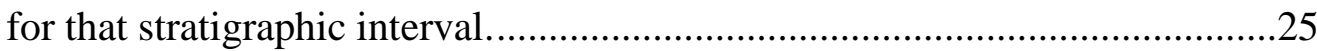

Table 3-4. Sand mineralogy of thin sections. All samples were averaged except for 0 to 1 meters, which is a single sample set because of sample loss. ..........26

Table 3-5. Root counts in thin sections. Total root count includes roots and root channels discovered independent of the grain count.

Table 3-6. Selective dissolution chemical data for stratigraphic sequence. .33

Table 3-7. Grouping information using the Tukey method with 95\% confidence for total pedogenic iron oxides $\left(\mathrm{Fe}_{\mathrm{d}}\right)$ and poorly crystalline iron oxides $\left(\mathrm{Fe}_{\mathrm{o}}\right)$ 


\section{LIST OF FIGURES}

Page

Figure 1-1. Late Quaternary sand dunes of the Morro Dune Complex in Estero Bay. Active dunes are adjacent to the coast, and younger parabolic dunes reside east of the active dunes. Morro barrier tip circled in red.

Figure adopted from Orme, 1990.

Figure 1-2. Timeline of geologic, glacial, and historic events pertinent to the central Californian coast.

Figure 1-3. Lamellae are prominent in the stratigraphic sequence studied (Photo credit: Lyssa A. Cousineau).

Figure 2-1. Oblique aerial view of marine terrace study area at Montaña de Oro State Park, Los Osos, California (Photo credit: Copyright @ 20022012 Kenneth \& Gabrielle Adelman, California Coastal Records Project, www.Californiacoastline.org). The specific site of study is outlined and enlarged.

Figure 2-2. View from beach of marine terrace study area at Montaña de Oro State Park, Los Osos, California (Photo credit: Lyssa A. Cousineau). Donovan Hall, who is $1.73 \mathrm{~m}$ tall, is shown for scale. .14

Figure 2-3. Sampling intervals depicted on oblique aerial view of marine terrace study area at Montaña de Oro State Park, Los Osos, California (Photo credit: Copyright (C 2002-2012 Kenneth \& Gabrielle Adelman, California Coastal Records Project, www.Californiacoastline.org). .15 
Figure 3-1. Average pH of stratigraphic sequence. Depth is in meters and error bars display standard error.

Figure 3-2. Average total carbon of stratigraphic sequence. The trend line displays exponential regression. Depth is in meters and error bars display standard error.

Figure 3-3. Average nitrogen of stratigraphic sequence. Depth is in meters and error bars display standard error.

Figure 3-4. Electrical conductivity of stratigraphic sequence. Depth is in meters and error bars display standard error. .21

Figure 3-5. Sand distribution as determined by particle size analysis in stratigraphic sequence. Depth is in meters and error bars display standard error.

Figure 3-6. Silt and clay distribution as determined by particle size analysis in stratigraphic sequence. Depth is in meters and error bars display standard error.

Figure 3-7. Sand mineralogy of stratigraphic sequence. Depth is in meters, error bars display standard error, and $\mathrm{x}$-axis is in percent.

Figure 3-8. Selected sand mineralogy of quartz in stratigraphic sequence. Depth is in meters, error bars display standard error, and x-axis is in percent.

Figure 3-9. Selected sand mineralogy of plagioclase in stratigraphic sequence. Depth is in meters, error bars display standard error, and x-axis is in percent. 
Figure 3-10. Quartz to plagioclase ratio in stratigraphic sequence. Depth is in meters and error bars display standard error.

Figure 3-11. Selected sand mineralogy of minor grains in stratigraphic sequence. Depth is in meters, error bars display standard error, and $\mathrm{x}$-axis is in percent. Quartz and plagioclase omitted from this figure to better depict concentrations of minor grains.

Figure 3-12. Cross section of root covered by mycorrhizal sheath (FitzPatrick, 1993) located 0 to 1 meters depth under cross-polars at $40 \mathrm{X}$ magnification (Photomicrograph credit: Lyssa A. Cousineau). .30

Figure 3-13. Filamentous, branching structures of fungal hyphae between grains located 9 to 10 meters depth under plane polarized light at $40 \mathrm{X}$ magnification (Photomicrograph credits: Lyssa A. Cousineau and Adrian Gallo).

Figure 3-14. Poorly crystalline iron oxides $\left(\mathrm{Fe}_{\mathrm{o}}\right)$ of stratigraphic sequence. Depth is in meters and error bars display standard error.

Figure 3-15. Total pedogenic iron oxides $\left(\mathrm{Fe}_{\mathrm{d}}\right)$ of stratigraphic sequence. Depth is in meters and error bars display standard error

Figure 3-16. Ratio of poorly crystalline iron oxides $\left(\mathrm{Fe}_{\mathrm{o}}\right)$ to total pedogenic iron oxides $\left(\mathrm{Fe}_{\mathrm{d}}\right)$ of stratigraphic sequence. Depth is in meters and error bars display standard error. 


\section{INTRODUCTION}

Dune geomorphology and coastal dune research are important because coastal dunes are dynamic. Coastal dunes experience periods of stabilization and inconstancy, and are subject to frequent and rapid changes due to sea level flux, shifts in vegetation, and anthropogenic activity (Carter et al., 1990; Orme, 1990 and 2005). These changes are compounded by modern global climate change, which is also altering coastal environments on a global scale. A lack of complete understanding of coastal dunes during this period of rapidly evolving landscapes may lead to the loss of these habitats for future generations.

Preservation is crucial for archaeological research. The value of archaeological sites is dependent on accurate provenance, or the age and location of artifacts. If archaeologists understand dune development and age, they will be afforded with a better opportunity to determine artifact provenance. Shell middens and archaeological sites created by the Chumash at Montaña de Oro State Park (CA State Parks, 1988; Orme, 1990 and 2005) are often associated to the dunes. Understanding of Chumash life ways will be enhanced by this research. The general public enjoys the central coast of California because of good weather, opportunities for recreational activities, and a plethora of native fauna and flora. These qualities have also been valuable to the Chumash for thousands of years. It is our job to preserve this heritage.

Several studies have analyzed the development of sand dunes, sandy soils, and underlying marine terraces (Aniku and Singer, 1990; Graham and O’Geen, 2010; Johnson et al., 2008; Little et al., 1978; Macphail and McAvoy, 2008; Miles and Franzmeier, 1981; Moody and Graham, 1995 and 1997; Reheis et al., 2005; Sauer et al., 
2010; Tsai et al., 2007; Tsai et al., 2010; Wagner et al., 2007), but characteristics of coastal dunes worldwide are still being compiled. This study analyzes stratigraphy of a select dune complex located within Montaña de Oro State Park. The goal of this study is to assess mineralogy and pedogenic features of sand dunes in a stratigraphic interval. The purpose is to determine whether these features significantly differ to reflect age differences with depth.

\section{Geologic Background}

Tectonic activity, sea level changes, and anthropogenic events are paramount to the evolution of the central California coast (Keller, 1992; Orme, 1990 and 2005). Montaña de Oro State Park is at the northwest end of the San Luis Range. This range, along with the Santa Lucia and Casmalia Hills Coastal Ranges developed over the last 5 to 3.5 million years due to folding and faulting along the Pacific and North American plates (Page et al., 1998).

More recently, the Morro Bay estuary began to form approximately 5-ka (Page et al., 1998). The current modern-day landscape of the Morro Bay estuary developed when an oceanic breach flooded a structurally unsound trough (Figure 1-1; CA State Parks, 1988; Orme, 1990 and 2005). Orme (1990) named the dune deposits in this area as the Morro Dune Complex.

The Morro Dune Complex has been the focus of study since the turn of the twentieth century. Marine terraces between Morro Bay and Santa Maria Valley were first noted by Fairbanks (1904). Fairbanks classified the rock sequence of Montaña de Oro as Monterey Shale (i.e., Monterey Formation). But this delineation was overturned by Hall (1973) who reclassified the shale, siltstone, and claystone as part of the Miguelito 
Member of the Pismo Formation (Keller, 1992; Orme, 1990). Later studies conducted by Pacific Gas and Electric Company $(1973,1988)$ and Cleveland (1978) followed Hall’s classification.

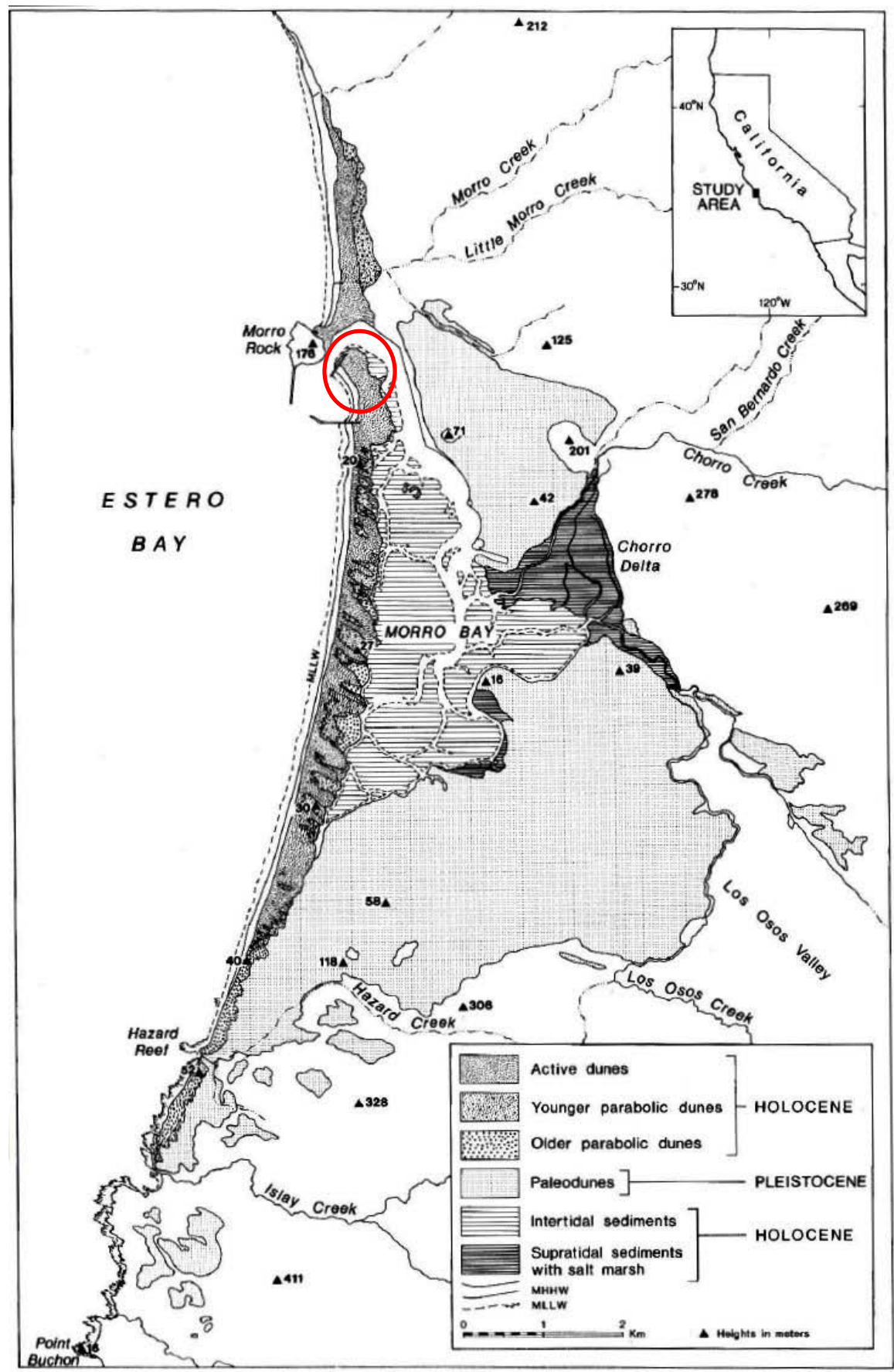

Figure 1-1. Late Quaternary sand dunes of the Morro Dune Complex in Estero Bay. Active dunes are adjacent to the coast, and younger parabolic dunes reside east of the active dunes. Morro barrier tip circled in red. Figure adopted from Orme, 1990. 


\section{Marine Terraces}

Marine terraces develop due to oscillating eustatic sea level highstands and lowstands. During an interglacial period, when less water is bound in glacial ice, sea levels rise. Periods of global sea level rise are known as transgressions, and periods of global sea level fall are termed regressions. Wave erosion from elevated sea level cuts a bedrock bench at the shoreline and thus creates a sea cliff that adjoins perpendicular to a modern wave-cut platform at the shoreline angle. These features are later uplifted by tectonic forces. The uplifted wave-cut platform is now a called a strath and the former (uplifted) sea cliff is now termed a riser. As the shoreline ridge and platform continues to uplift and waves from the modern sea level cut into the bedrock bench, additional straths and risers are formed and a staircase of shoreline platforms emerges. The top of the staircase is inhabited by the oldest shoreline platforms; the straths and risers become progressively older inland and with increasing elevation. The modern wave-cut platform overlain by the current coastal shore is generally indicative of the most recent coastal activity. However, sea level regressions can create platforms which later exist under water during a eustatic sea level highstand or interglacial period.

Orme (1990) identified intermittent uplift of shoreline ridges in the Morro Dune Complex since about 100-ka (Figure 1-2). The current average uplift rate for marine terraces located between Islay Creek and Hazard Canyon in Montaña de Oro State Park, which is very close to the study site, is approximately $0.24 \mathrm{~m} / \mathrm{ka}$ (Hanson et al., 1994).

During eustatic sea level lowstands, sediments previously below sea level become subject to eolian processes. Winds dominantly from the west (CA State Parks, 1988; Orme, 1990) transport sand dunes inland to cover the wave-cut platforms. These dunes 
are migratory and are constantly being reworked by the winds, but coastal shrubs and vegetation create stationary areas within otherwise mobile modern sand dunes.

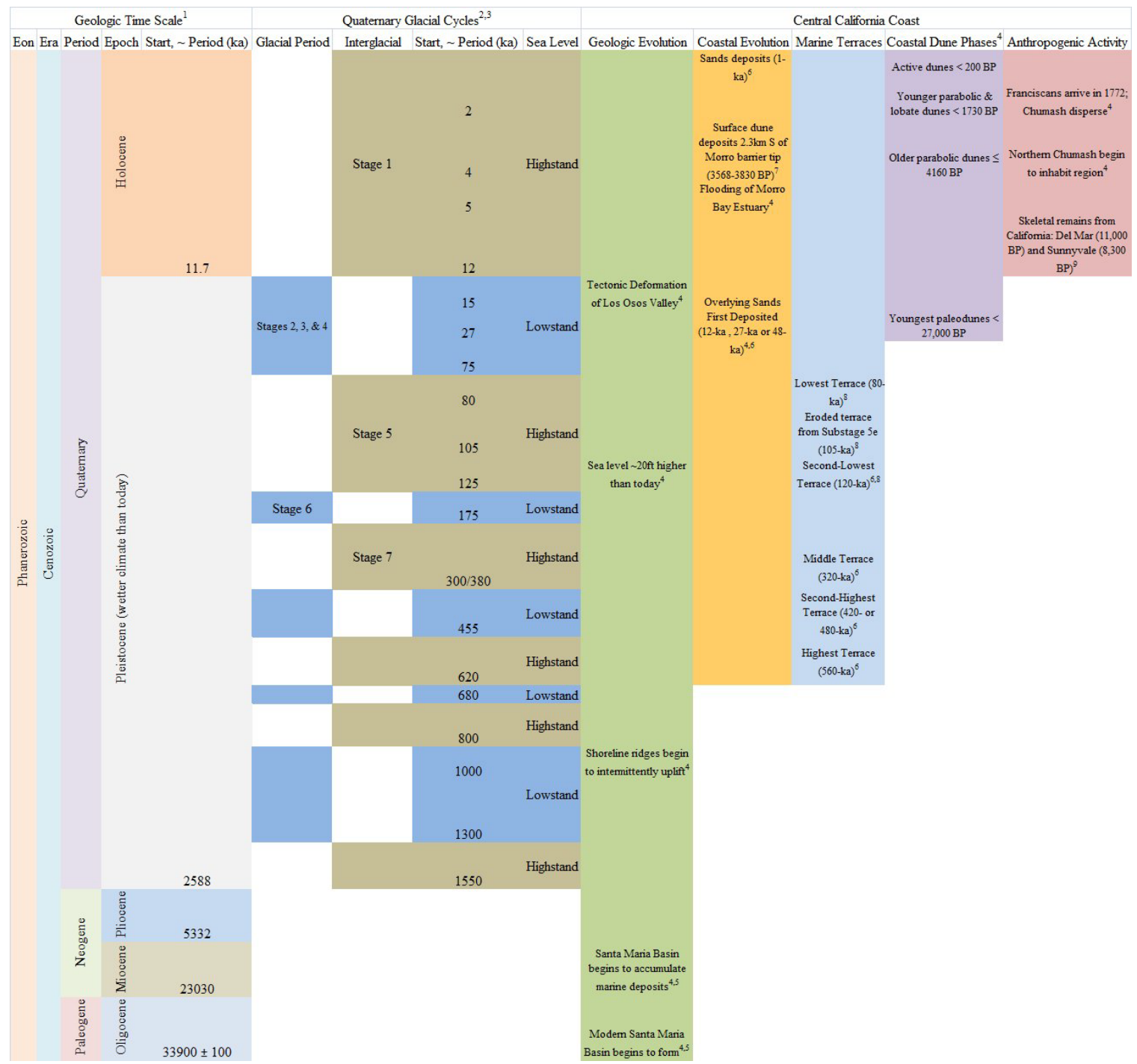

Figure 1-2. Timeline of geologic, glacial, and historic events pertinent to the central Californian coast.

\section{Relative Ages}

Dates of the marine terraces at Morro Bay and Montaña de Oro State Park have been disputed over the years. Using a combination of amino acid racemization, uraniumseries dating from coral and vertebrate bone samples, invertebrate faunal assemblages,

${ }^{1}\left(\right.$ Ogg, 2010) ${ }^{2}$ (Muhs, 2012) ${ }^{3}$ (Gibbard and Kolfschoten, 2004) ${ }^{4}$ (Orme, 1990) ${ }^{5}$ (CA Dept. of Water Resources, 2002) ${ }^{6}$ (Moody and Graham, 1995) ${ }^{7}$ (Jack Meyer, Far Western Anthropological Research Group, Inc., personal communication, 2012) ${ }^{8}$ (Hanson et al., 1994) ${ }^{9}$ (Bischoff and Rosenbauer, 1981) 
and comparisons of terrace elevation with altitudes of previously-dated terraces, Hanson et al. (1994) determined that an array of twelve elevated, essentially flat-lying marine terraces exist in the San Luis Range between Morro Bay and the northern boundary of Santa Maria Valley.

According to this study, the youngest and lowest two terraces of the dozen correlate consecutively with sea-level transgressions at 80-ka and 120-ka. Hanson et al. (1994) concluded that a thin terrace dating to the 105-ka transgression was eroded and subsequently not preserved. A concurrent study by Moody and Graham (1995) determined that the lowest terrace dates to the 120-ka interglacial, and that overlying sands were first deposited during the Pleistocene (12-ka to 27-ka or 48-ka) and reworked later during the Holocene (1-ka).

\section{Basal Dune Chronology}

Modern beaches and dune fields, which date from the late Pleistocene to the early Holocene, overlie the marine terraces in Morro Bay and at Montaña de Oro State Park (Hanson et al., 1994; Orme, 1990 and 2005). Sands of these beaches and dune fields were deposited on the San Luis Range during the last eustatic sea level lowstand at about 15-ka (CA State Parks, 1988; Orme, 1990 and 2005). Dates from Gibson (1981) and Orme (1990) indicate that the surface dune deposits located $2.3 \mathrm{~km}$ south of the Morro barrier tip (see Figure 1-1) date between 3568 and 3830 BP (before present) (Jack Meyer from Far Western Anthropological Research Group, Inc., personal communication, 2012). The study site is located relatively close to the surface dune deposits dated. Therefore, surface dune deposits of the study site likely correlate with these ages. Additional radiocarbon 
dating of buried soils indicates that dunes which were formed during the last drop in sea level have since partially eroded (Orme, 1990).

Orme (1990) defined four major phases of dune stabilization in Morro Bay (Table 1). His work suggests that the modern dunes of the Morro Dune Complex are experiencing a period of instability, and that dune erosion is marked and rapid in the region today. It is likely that the basal layer of the study site corresponds with the youngest paleodunes which were deposited on the San Luis Range between 15-ka to 30ka (CA State Parks, 1988; Orme, 1990 and 2005).

Table 1-1. The four major coastal dune phases of stabilization and their maximum ages in the Morro Dune Complex (Orme, 1990).

\begin{tabular}{lll}
\hline Phase & Expression & $\begin{array}{l}\text { Maximum age } \\
\text { (uncalibrated) }\end{array}$ \\
\hline Holocene III & Active dunes & $<200 \mathrm{BP}$ \\
& $\begin{array}{l}\text { Younger parabolic and } \\
\text { lobate dunes }\end{array}$ & $<1,730 \mathrm{BP}$ \\
Holocene II & Older parabolic dunes & $\leq 4,160 \mathrm{BP}$ \\
Holocene I & & \\
$\begin{array}{l}\text { Late } \\
\text { Pleistocene }\end{array}$ & Youngest paleodunes & $<27,000 \mathrm{BP}$ \\
\hline
\end{tabular}

\section{Sand Dune Development}

Coastal watersheds brought inland sediment to the coasts by flood events, which were then reworked by waves, winds, and currents to form the modern sand dunes found along the Pacific coast. The collection of sediment on these coasts was most prevalent during the wetter climate of the Pleistocene. However, tectonic deformation of Los Osos Valley toward the end of the Pleistocene limited sediment delivery (Orme, 2005).

Dunes are influenced by beach profile characteristics, wind regimes, and sediment grain size distribution (Carter et al., 1990). Sand deposits, which make up coastal dunes, are positioned in response to obstructions including vegetation and anthropogenic 
obstacles such as jetties and buildings. The wave-cut platforms at Montaña de Oro State Park are overlain with a thin (1 to $2 \mathrm{~m}$ ) deposit of gravel and marine sand, and a thick (up to $30 \mathrm{~m}$ ) deposit of eolian sand, alluvium, and colluvium (Hanson et al., 1994; Moody and Graham, 1997; Orme, 1990).

\section{Lamellae}

The dune complex for this study contains an extensive array of lamellae throughout the soil section (Figure 1-3). The Keys to Soil Taxonomy, Eleventh Edition (NRCS, 2010) defines lamellae as the following:

A lamella is an illuvial horizon less than $7.5 \mathrm{~cm}$ thick formed in unconsolidated regolith more than $50 \mathrm{~cm}$ thick. Each lamella contains an accumulation of oriented silicate clay on or bridging the sand and silt grains (and rock fragments if any are present). Each lamella is required to have more silicate clay than the overlying eluvial horizon.

In general, lamellae number, color, and thickness increase with pedogenic development (Schaetzl, 2001). Specifically, to some threshold depth below which clay illuviation is negligible, the process of lamellae development increases with depth and age of a soil sequence. This is because lamellae migrate downward in a soil sequence. The clay content moves from upper to lower lamellae during development (Soil Survey Staff, 1999). Because of this developmental trait, older lamellae are present at deeper depths in the soil sequence. Generally, clay content is greatest near the middle of the soil sequence where lamellae are better developed. But because the wetting front is not perfectly horizontal, clays from the lower lamellae are eventually eroded away. Therefore, clay content is least prevalent near the top and bottom of the sequence (Schaetzl, 2001; Soil Survey Staff, 1999). 


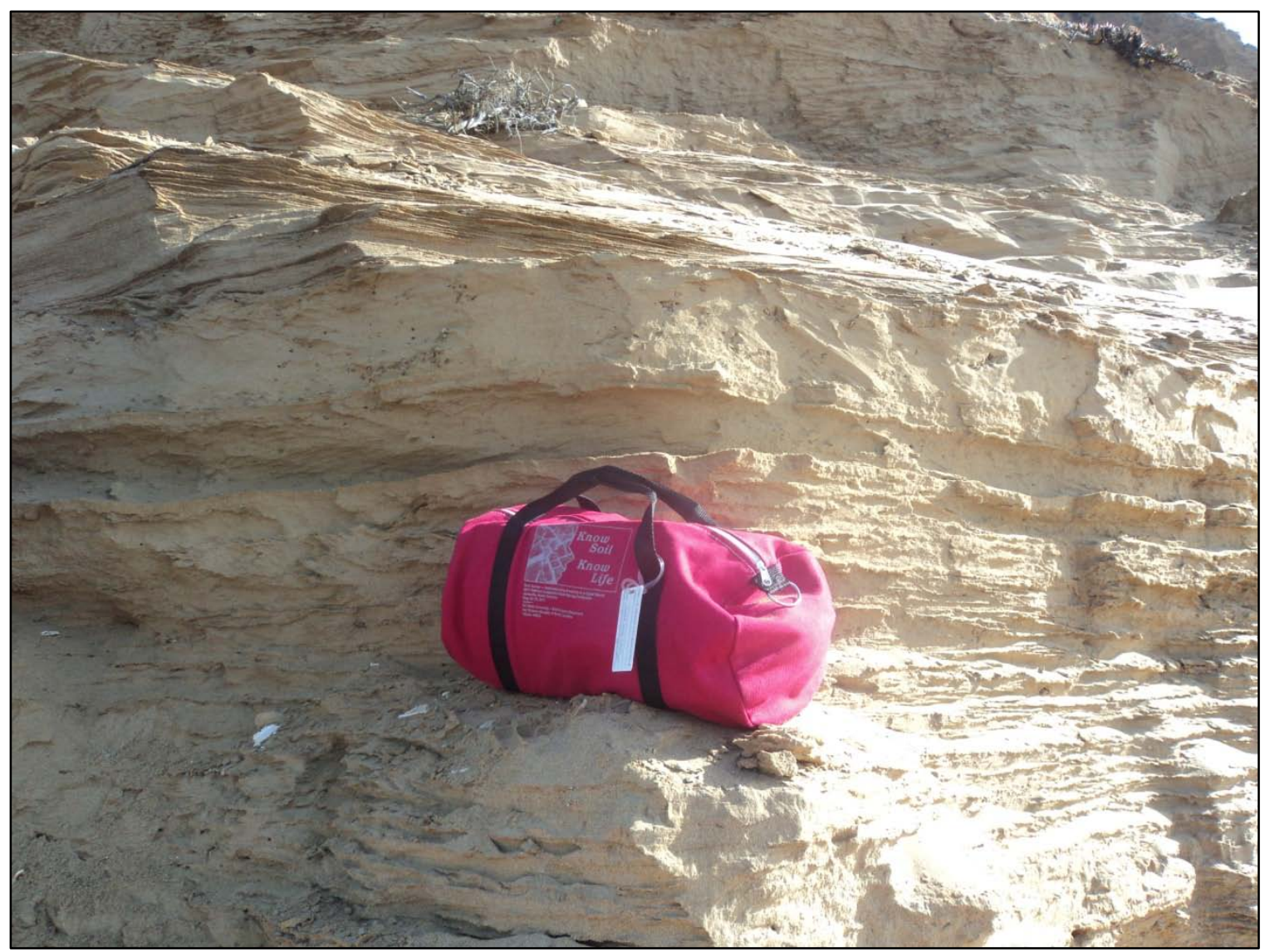

Figure 1-3. Lamellae are prominent in the stratigraphic sequence studied (Photo credit: Lyssa A. Cousineau).

\section{Anthropogenic Activity}

Evidence along the coast including shell middens, stone projectile points, and hearths indicate that a relatively modest number of people lived in and around Los Osos during the Early Holocene (CA State Parks, 1988; Orme, 1990 and 2005). Additionally, radiocarbon dates of Native American middens indicate that the dunes were inhabited by a greater number of people between 4-ka to 2-ka. The Northern Chumash people began to inhabit the region after 4-ka. Their semi-nomadic lifestyle came to an end around 1772 BP, when the Franciscans founded Mission San Luis Obispo de Tolosa (CA State Parks, 1988; Orme, 2005). 
Spanish colonization initiated an agricultural era in which most of the coast (including Montaña de Oro) was heavily grazed by livestock (CA State Parks, 1988; Orme, 2005). During the mid-twentieth century, urbanization and recreational lands curtailed heavy grazing in many areas including the focus of this research. Since urbanization, the dunes have been subjected to several natural and anthropogenic disturbances including military exercises, off-road vehicular traffic, and fire. 


\section{MATERIALS AND METHODS}

\section{Study Area}

This study was conducted in Montaña de Oro State Park, located on the central California coast eighteen kilometers northwest of San Luis Obispo in San Luis Obispo County (Figure 2-1; CA State Parks, 1988).

\section{Climate}

San Luis Obispo County soils are in a xeric moisture regime. The Mediterranean climate of the region is characterized by mild temperatures with warm dry summers and cool wet winters, as well as minimal diurnal fluctuations (CA State Parks, 1988; Orme, 1990). The region has an average annual temperature of about 13 to $16^{\circ}$ Celsius. Fog occurs frequently along the coast during the summer months. Rainfall averages about 68

cm per year. Precipitation typically occurs during the fall and winter. There are generally forty to sixty days of precipitation per year. Winds are predominantly from the WNW and NW.

\section{Vegetation}

Coastal strand vegetation on the Morro dunes includes ice plant (Carpobrotus chilensis), sea-rocket (Cakile maritima), sand verbena (Abronia latifolia), bush lupine (Lupinus chamissonis), and perennial veldt grass (Ehrharta calycina) (Brady, 1978; CA State Parks, 1988; Lynn E. Moody, PhD, personal communication, 2012). Young terraces are home to Morro manzanita (Arctostaphylos morroensis), buck brush (Ceanothus cuneatus), as well as annual grasses (Moody and Graham, 1995). Older terraces are inhabited by annual shrubs and grasses, poison oak (Toxicodendron diversilobum), California sagebrush (Artemesia californica), and coyote brush (Baccharis pilularis). 
Morro Manzanita and chamise (Adenostoma fasciculatum) comprise most of the vegetation located on the oldest terraces.

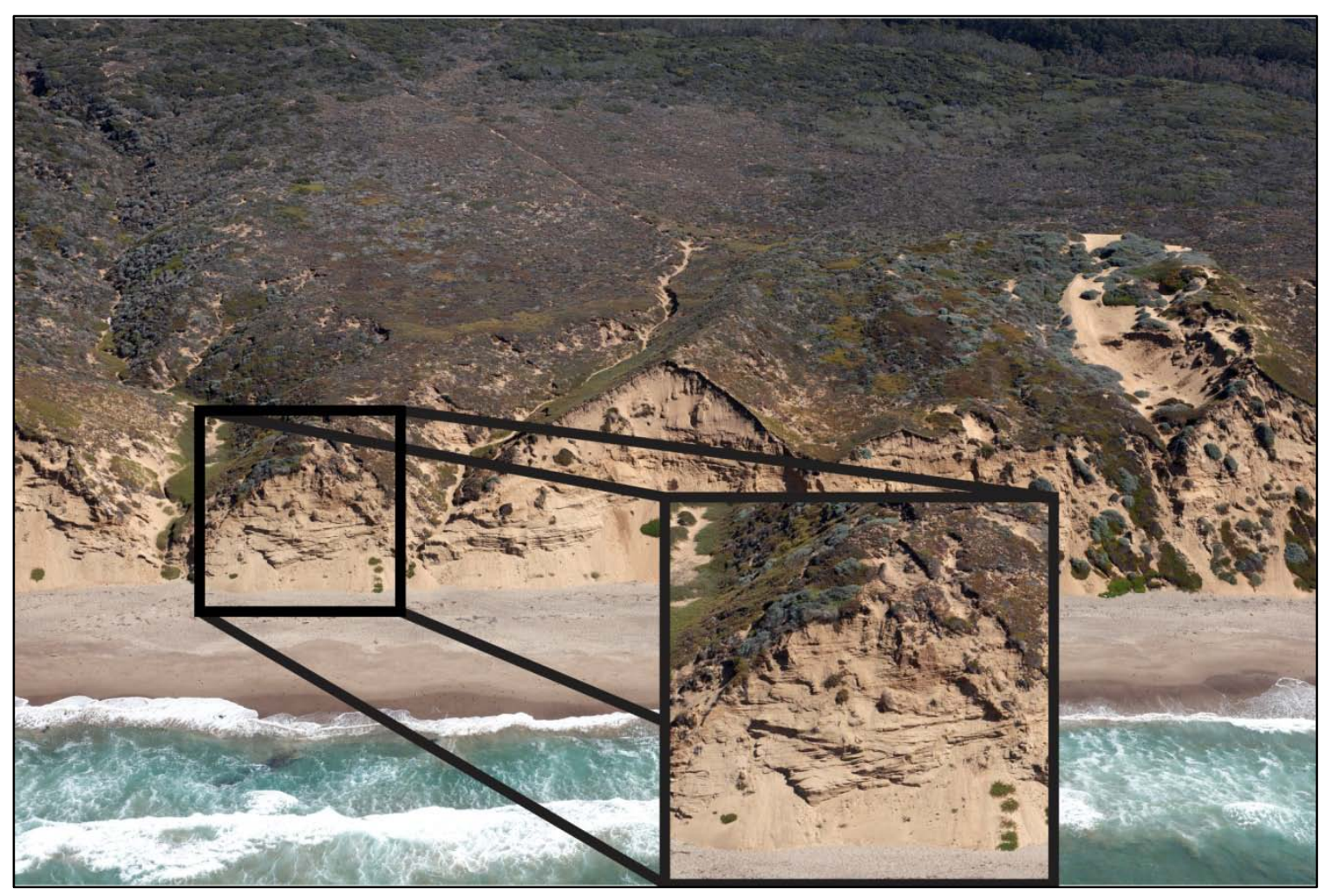

Figure 2-1. Oblique aerial view of marine terrace study area at Montaña de Oro State Park, Los Osos, California (Photo credit: Copyright (c) 2002-2012 Kenneth \& Gabrielle Adelman, California Coastal Records Project, www.Californiacoastline.org). The specific site of study is outlined and enlarged.

\section{Soils}

Moody et al. (1994) classified recent Holocene deposits near the study site as mixed, thermic, Argic Xeropsamments. Under the current Keys of Soil Taxonomy, this soil is classified as a mixed, thermic, Lamellic Xeropsamment (NRCS, 2010). South of the Morro Bay barrier beach the dunes are mapped as Dune Land (miscellaneous land area) and Baywood fine sand (sandy, mixed, thermic Entic Haploxerolls), that are composed of eolian deposits. Santa Lucia shaly clay loam (clayey-skeletal, mixed, superactive, thermic Pachic Ultic Haploxerolls) and Arnold loamy sand (mixed, thermic 
Typic Xeropsamments) are also present. These complexes are composed of residuum from weathered shale and are characterized by steep slopes, seepage and piping features, shallow depth to rock, and unsuitability for construction and engineering (California Soil Resource Lab, 2011; CA State Parks, 1988; NRCS, 2010 and 2011; Soil Survey Division Staff, 1993). Steeper slopes in the area consist of the Lopez-Rock outcrop complex (loamy-skeletal, mixed, superactive, thermic Lithic Ultic Haploxerolls) that support coastal sage scrub and reflect the features of regional soils.

\section{Methods}

\section{Sample Collection}

The study site is located about $1.5 \mathrm{~km}$ north of Hazard Canyon at Montaña de Oro State Park, Los Osos, California. The sampling site was chosen for prominent pedogenic features such as lamellae, and a relative lack of colluvial sediments at the base of the sea cliff (Figure 2-2). The sand deposits lie on top of a modern wave-cut platform. The shoreline angle is covered by colluvial sediments. The sampling protocol was approved by a statistician before collection. Five replicates of each interval were sampled. Samples were collected from the vertical exposure of one dune face by stratified random sampling at 1.0-m vertical intervals (Figure 2-3; Penneck et al., 2008). Forty-five samples in total were collected, with five samples from each 1.0-m vertical interval. A colluvial apron is present up to $1.5 \mathrm{~m}$ at the base of the dune formation and was not sampled for this study. Two intervals near the top of the dune at 3 to 5 meters depth could not be collected because of inaccessibility. Two samples from each interval were collected to make thin sections, but one of the samples from 0 to 1 meters depth was lost during transport. 


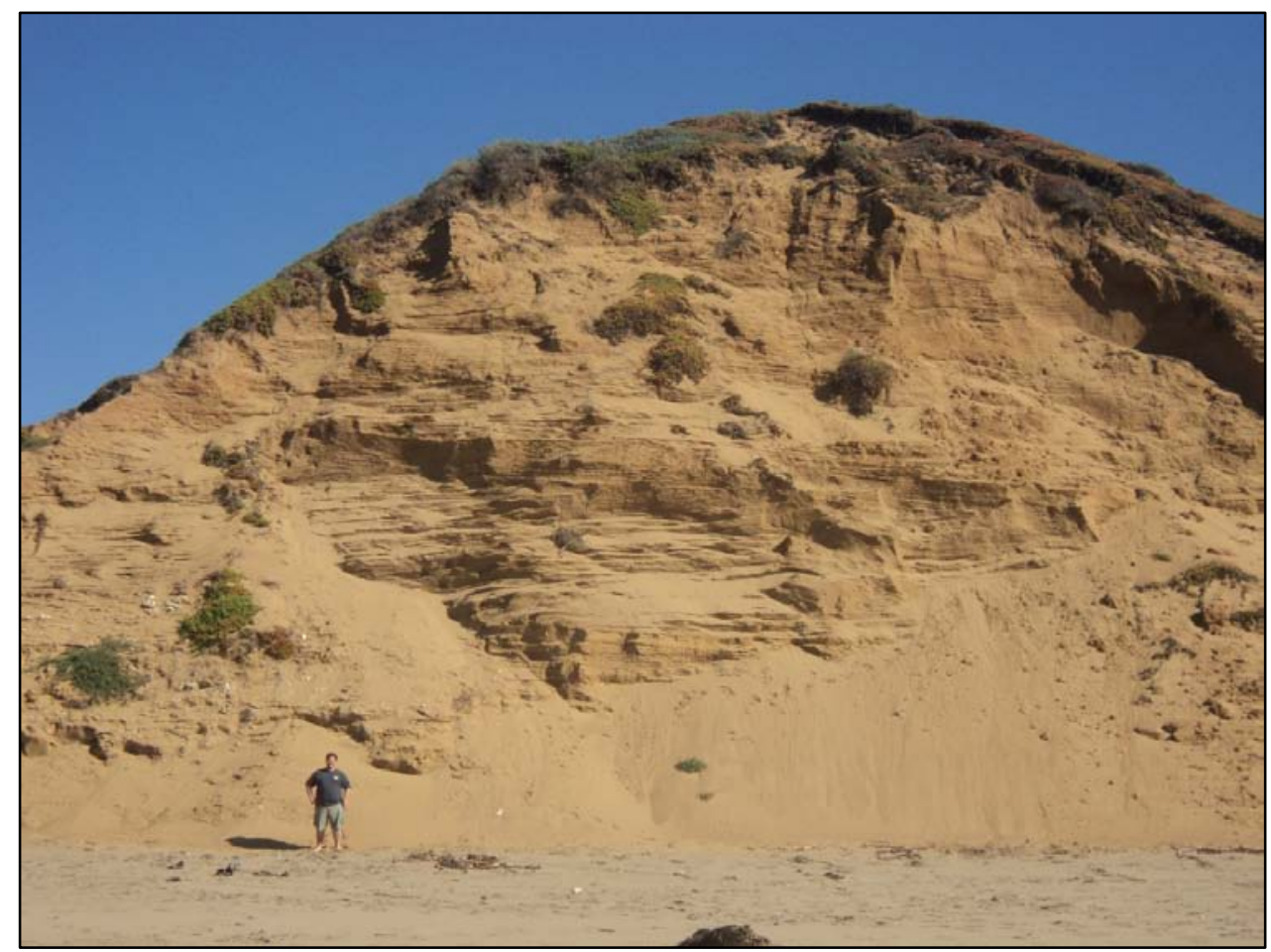

Figure 2-2. View from beach of marine terrace study area at Montaña de Oro State Park, Los Osos, California (Photo credit: Lyssa A. Cousineau). Donovan Hall, who is $1.73 \mathrm{~m}$ tall, is shown for scale. 


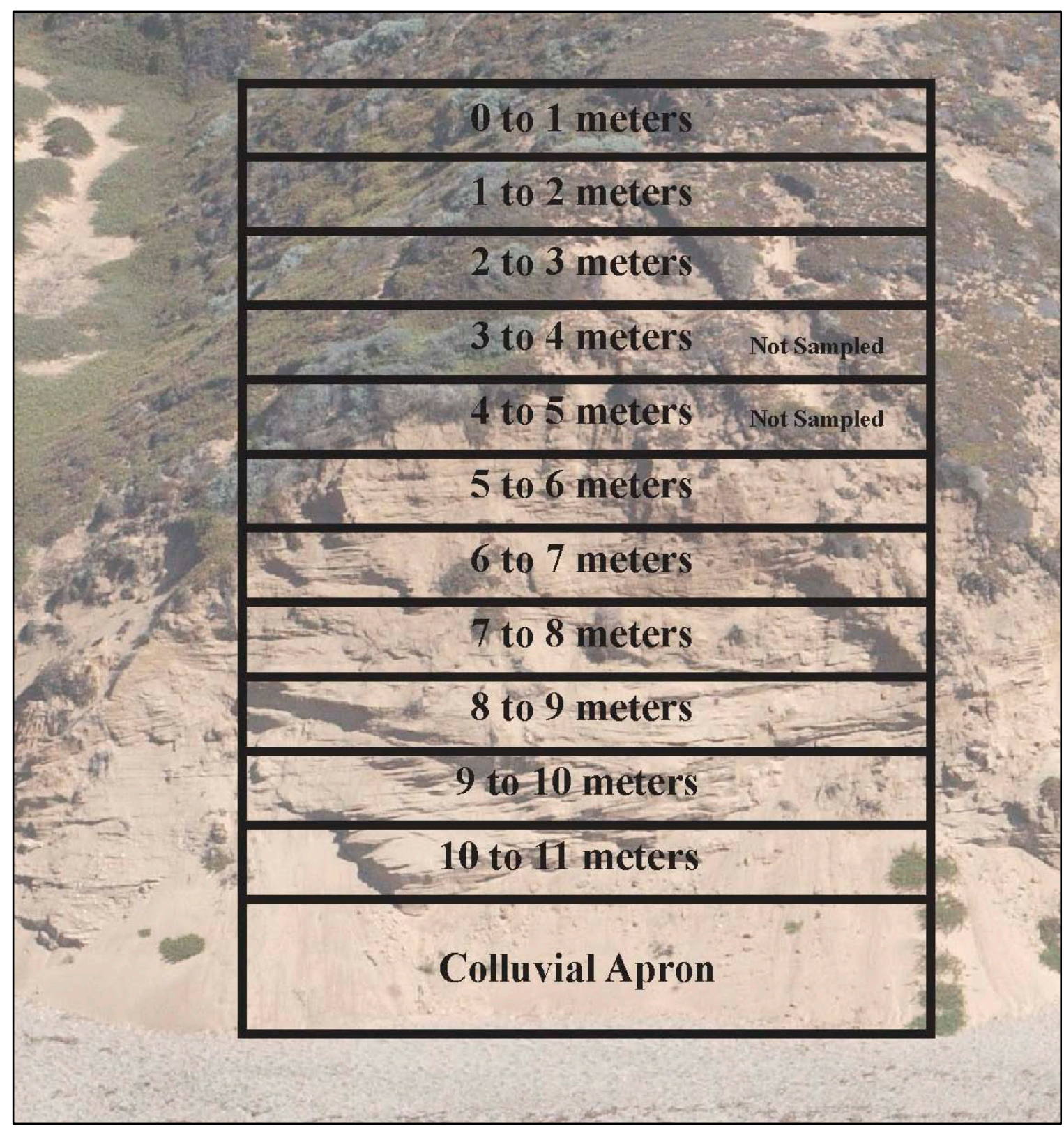

Figure 2-3. Sampling intervals depicted on oblique aerial view of marine terrace study area at Montaña de Oro State Park, Los Osos, California (Photo credit: Copyright (C) 2002-2012 Kenneth \& Gabrielle Adelman, California Coastal Records Project, www.Californiacoastline.org).

\section{Laboratory Analyses}

Particle-size analysis by hydrometer and sieve was conducted following chemical dispersion using 1M sodium hexametaphosphate and physical dispersion for five minutes in an industrial blender (Gee and Bauder, 1986; Kroetsch and Wang, 2008; Sherard et al., 
1976; Volk, 1937). Electrical conductivity and $\mathrm{pH}$ were determined using a 1:1 soil/water paste. Total soil carbon and nitrogen contents were determined using a VarioMax CNS combustion analyzer (Rutherford et al., 2008; Skjemstad and Baldock, 2008).

Samples were tested for presence of carbonates with $10 \%$ hydrochloric acid; the samples did not contain detectable carbonates. Organic matter was removed by sodium hypochlorite in preparation for two selective dissolution techniques (Courchesne and Turmel, 2008; Soukup et al., 2008). These methods were used to extract pedogenic iron oxides. Ammonium oxalate in the dark extracts poorly crystalline iron oxides (ferrihydrite) from samples (Fey and LeRoux, 1977; Hodges and Zelazny, 1980; Schwertmann, 1964; Shang and Zelazny, 2008). Citrate-bicarbonate-dithionite (CBD) extracts free iron oxides (hematite, goethite, and maghemite) from samples (Jackson et al., 1986; Mehra and Jackson, 1960; Shang and Zelazny, 2008). Pedogenic iron oxides were then quantified from each extractant by flame atomic absorption spectrometry on a SpectrAA (Wright and Stuczynski, 1996).

Fifteen thin sections from varying stratigraphic intervals on the dune were analyzed using petrographic microscopy following procedure presented in Vepraskas and Wilson (2008). Sand mineralogy was identified and quantified using polarized light microscopy through grain counts of the thin sections with at least 300 grains per sample (FitzPatrick, 1993; Lynn et al., 2008).

\section{Statistical Analyses}

Numerical data were analyzed by statistical regression in MiniTab. Regression analysis assumes a linear trend and normal residuals with equal variability. Fitted line plots were graphed with four-in-one residual plots to determine fit. P-factors were 
determined from these linear regression analyses. Grouping information was determined by the Tukey method with 95\% confidence in conjunction with a general linear model ANOVA. ANOVA assumes normal residuals with equal variability. Data from sampling interval I, with a depth of 5 to 6 meters, were omitted from the regression analyses because those observations were taken on a different day. A table of data for the statistical regressions is presented in Appendix A. 


\section{RESULTS}

\section{Chemical Features}

Results of five replicate samples for each stratigraphic interval were averaged together to provide mean data at each 1.0-m vertical interval. Mean electrical conductivity, $\mathrm{pH}$, nitrogen, and total carbon are presented in Table 3-1. Sands from this stratigraphic interval are generally acidic $(\mathrm{pH}<7)$. The $\mathrm{pH}$ does not significantly ( $\mathrm{P}=0.639)$ increase with depth. The $\mathrm{pH}$ locally and gradually increases with depth down to 6 meters. Between 6 to 9 meters, the $\mathrm{pH}$ is basic $(\mathrm{pH}>7)$ (Figure 3-1). The $\mathrm{pH}$ is then low between 9 to 11 meters.

Total carbon content is greatest at 0 to 1 meters and decreases with depth (Figure 3-2). Regression analysis indicates that total carbon content significantly decreases with depth by exponential regression $(0<\mathrm{P}<0.000)$. Grouping information using the Tukey method with 95\% confidence indicates that total carbon content between 0 to 1 meters is significantly higher than total carbon content between all other depths.

Nitrogen content is also greatest between 0 to 1 meters, then decreases, but is high again between 9 to 10 meters depth (Figure 3-3). Analysis of nitrogen content between 9 to 10 meters was completed in duplicate to confirm that nitrogen increases between 9 to 10 meters. Regression analysis indicates that nitrogen content significantly decreases with depth by linear regression $(0<\mathrm{P}<0.000)$. Nitrogen content decreases by $0.027707 \%$ per one meter. Grouping information using the Tukey method with 95\% confidence indicates that nitrogen content between 0 to 1 meters is significantly higher than nitrogen content between all other depths. 
The overall values of electrical conductivity are quite low (Figure 3-4). Electrical conductivity does not significantly decrease with depth $(\mathrm{P}=0.348)$. Electrical conductivity in this stratigraphic interval varies slightly with a significant increase at 5 to 6 meters. Nutrients and salts, as depicted by the electrical conductivity measurements, are present at 0 to 2 meters and 9 to 11 meters.

Table 3-1. Selected chemical features of stratigraphic sequence.

\begin{tabular}{cccccc}
\hline Depth & Sampling Interval & Mean EC & Mean pH & Mean N & Mean TC \\
\hline $\mathrm{m}$ & & $\mathrm{mS} \mathrm{cm}^{-1}$ & & $\%$ & $\%$ \\
\hline $0-1$ & $\mathrm{H}$ & 0.10 & 5.59 & 0.04 & 0.46 \\
$1-2$ & $\mathrm{G}$ & 0.05 & 6.15 & 0.01 & 0.08 \\
$2-3$ & $\mathrm{~F}$ & 0.00 & 6.90 & 0.01 & 0.10 \\
$3-4$ & & & & & \\
$4-5$ & & & & & \\
$5-6$ & $\mathrm{I}$ & 0.17 & 6.28 & 0.01 & 0.04 \\
$6-7$ & $\mathrm{E}$ & 0.01 & 7.65 & 0.01 & 0.01 \\
$7-8$ & $\mathrm{D}$ & 0.00 & 7.30 & 0.01 & 0.01 \\
$8-9$ & $\mathrm{C}$ & 0.00 & 7.54 & 0.01 & 0.02 \\
$9-10$ & $\mathrm{~B}$ & 0.07 & 5.33 & 0.04 & 0.02 \\
$10-11$ & $\mathrm{~A}$ & 0.03 & 5.74 & 0.01 & 0.02 \\
$11.3-13$ & Colluvial Apron & & & \\
\hline EC = electrical conductivity, N = nitrogen, TC = total carbon &
\end{tabular}




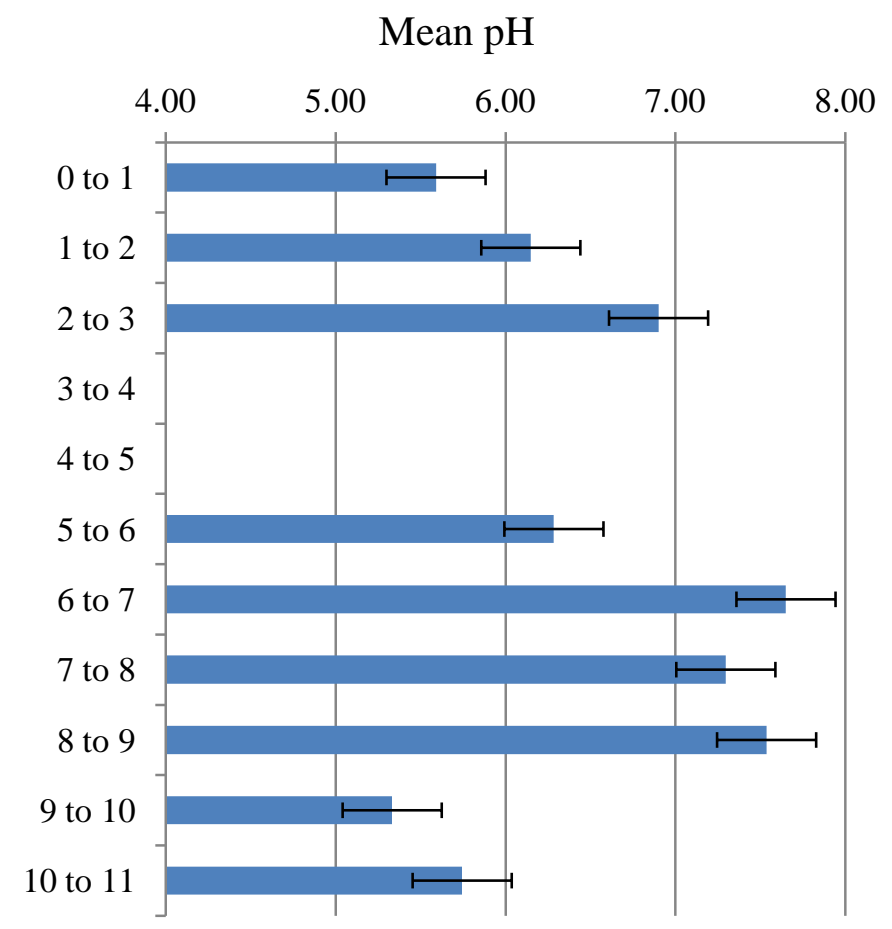

Figure 3-1. Average pH of stratigraphic sequence. Depth is in meters and error bars display standard error.

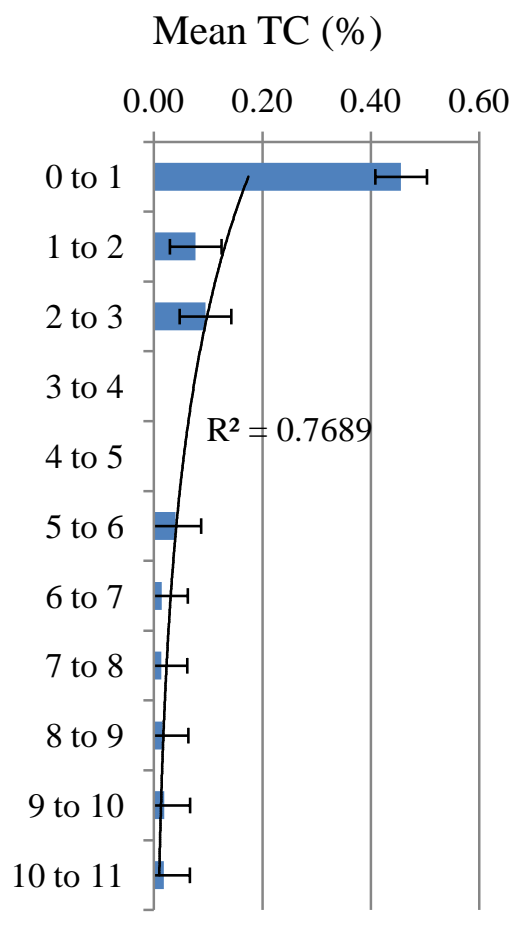

Figure 3-2. Average total carbon of stratigraphic sequence. The trend line displays exponential regression. Depth is in meters and error bars display standard error. 


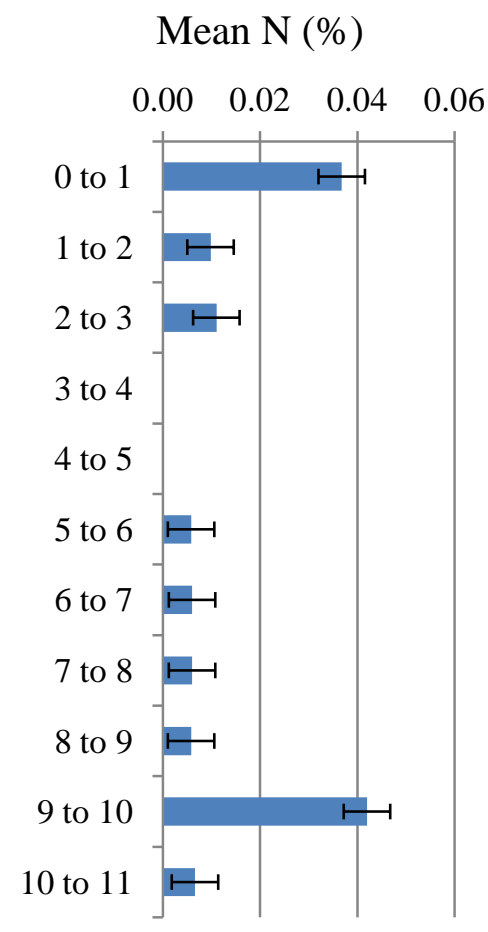

Figure 3-3. Average nitrogen of stratigraphic sequence. Depth is in meters and error bars display standard error.

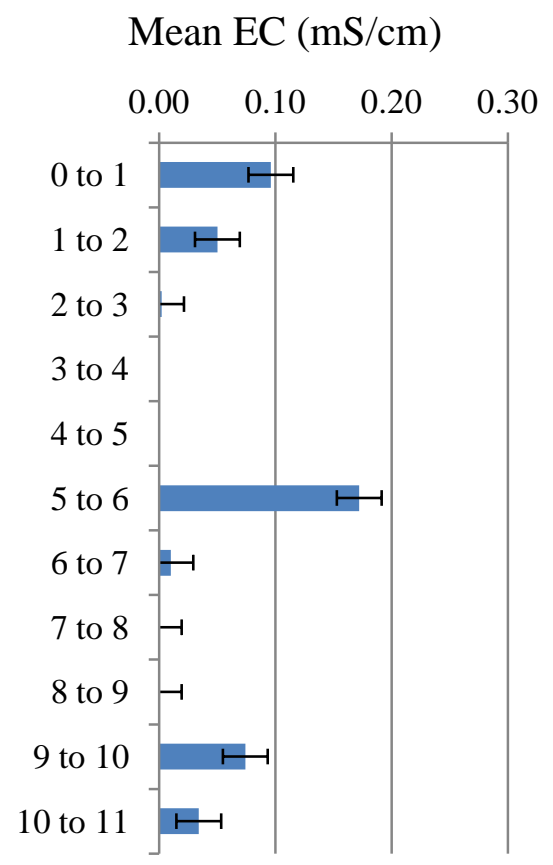

Figure 3-4. Electrical conductivity of stratigraphic sequence. Depth is in meters and error bars display standard error. 


\section{Texture}

\section{Particle Size Distribution}

All samples in the stratigraphic sequence are primarily composed of $97 \%$ to $100 \%$ sand with $<1 \%$ silt and $\sim 2 \%$ or less clay (Table 3-2). Sand content significantly increases with depth ( $\mathrm{P}=0.001)$ (Figure 3-5). Sand content increases $0.2298 \%$ per one meter. At 2 to 3 meters and 8 to 9 meters there are small increases in sand content relative to the general trend. Grouping information using the Tukey method with 95\% confidence indicates that sand content between 1 to 2 meters and sand content between 8 to 9 meters are significantly different than sand content between all other depths.

Clay content significantly decreases with depth $(\mathrm{P}=0.002)$ (Figure 3-6). Clay content is relatively high between 5 to 6 meters depth. Clay content decreases by 0.17304\% per one meter. Grouping information using the Tukey method with 95\% confidence indicates that clay content between 6 to 7 meters and clay content between 8 to 9 meters are significantly different than clay content between all other depths.

There is virtually no silt in the stratigraphic sequence, and silt does not significantly decrease with depth $(\mathrm{P}=0.099)$ (Table 3-2 and Figure 3-6). Silt content is present at almost $1 \%$ or less in the stratigraphic sequence and is less abundant between 5 to 9 meters. 
Table 3-2. Particle size distribution of sand grains.

\begin{tabular}{ccccc}
\hline Depth & Sampling Interval & \multicolumn{3}{c}{ Particle Size Distribution } \\
\hline $\mathrm{m}$ & & \% Sand & \% Silt & \% Clay \\
\hline $0-1$ & H & 97.2 & 0.6 & 2.2 \\
$1-2$ & G & 96.8 & 1.2 & 2.0 \\
$2-3$ & F & 98.2 & 0.8 & 1.0 \\
$3-4$ & & & & \\
$4-5$ & & & & \\
$5-6$ & I & 97.4 & 0.0 & 2.6 \\
$6-7$ & E & 97.6 & 0.0 & 2.4 \\
$7-8$ & D & 99.4 & 0.2 & 0.4 \\
$8-9$ & C & 100.0 & 0.0 & 0.0 \\
$9-10$ & B & 98.6 & 0.6 & 0.8 \\
$10-11$ & A & 99.2 & 0.6 & 0.2 \\
$11.3-13$ & Colluvial Apron & & & \\
\hline
\end{tabular}

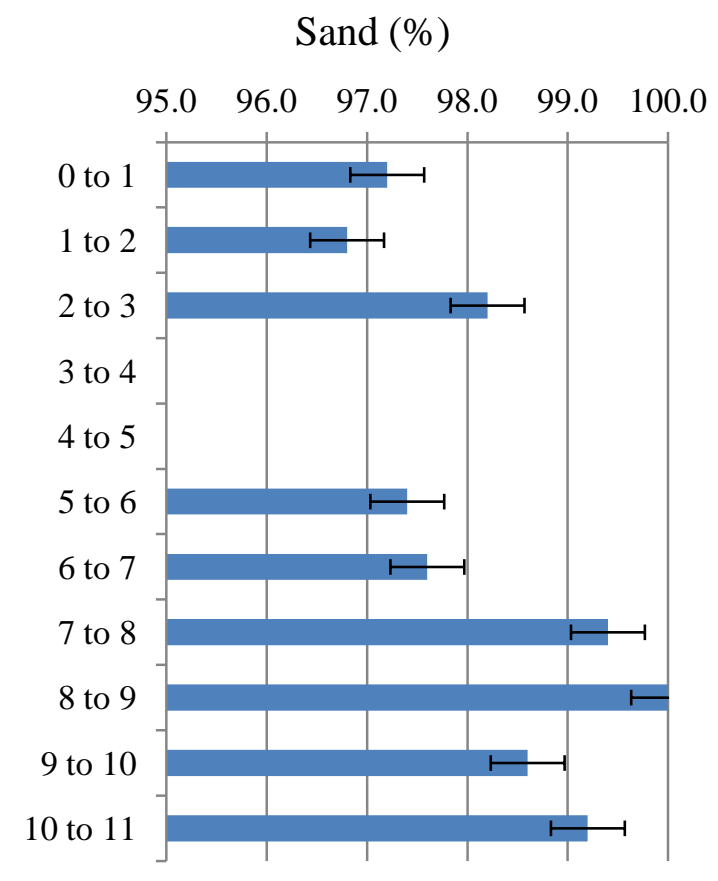

Figure 3-5. Sand distribution as determined by particle size analysis in stratigraphic sequence. Depth is in meters and error bars display standard error. 


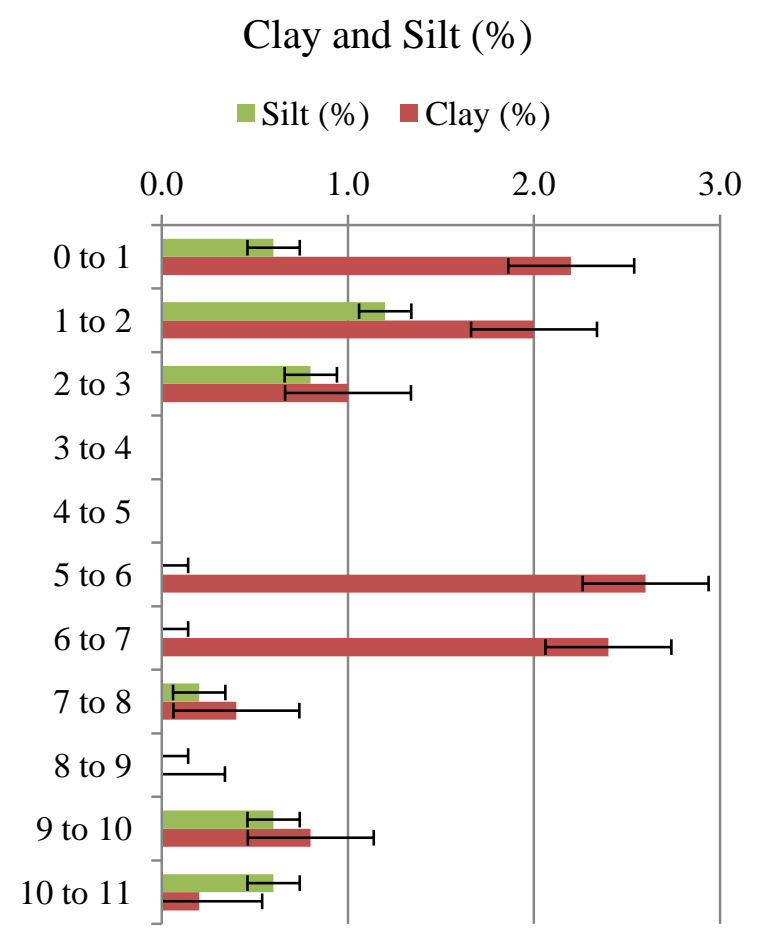

Figure 3-6. Silt and clay distribution as determined by particle size analysis in stratigraphic sequence. Depth is in meters and error bars display standard error.

\section{Roundness and Sorting}

Most thin sections are dominated by subangular sand grains (Table 3-3). At 2 to 3 meters and 9 to 10 meters, grains are predominantly subrounded. The sands are well sorted, and primarily very fine in texture $(0.125-0.063 \mathrm{~mm}$ in diameter). Sands range from coarse $(1-0.5 \mathrm{~mm})$ in size to very fine $(0.125-0.063 \mathrm{~mm})$, and have a phi $(\phi)$ scale range of 0 to $4 \phi$. However, sand distribution is strongly dominated by very fine ( 3 to $4 \phi$ ) and fine sands (2 to $3 \phi)$. 
Table 3-3. Prominent sorting and roundness of sand grains. Roundness not determined at 5 to 6 meters because thin sections were not produced for that stratigraphic interval.

\begin{tabular}{|c|c|c|c|}
\hline Depth & Sampling Interval & Prominent $\sigma$ & Roundness \\
\hline $\mathrm{m}$ & & $\phi$ & \\
\hline $0-1$ & $\mathrm{H}$ & 3 & sa \\
\hline $1-2$ & G & 3 & sa \\
\hline $2-3$ & $\mathrm{~F}$ & 3 & sr \\
\hline \multicolumn{4}{|l|}{$3-4$} \\
\hline \multicolumn{4}{|l|}{$4-5$} \\
\hline $5-6$ & I & 2 & \\
\hline $6-7$ & E & 2 & sa \\
\hline $7-8$ & D & 3 & sa \\
\hline $8-9$ & $\mathrm{C}$ & 3 & sa \\
\hline $9-10$ & B & 3 & $\mathrm{sr}$ \\
\hline $10-11$ & A & 3 & sa \\
\hline $11.3-13$ & Colluvial Apron & & \\
\hline
\end{tabular}

\section{Mineralogy and Micromorphology}

Sand mineralogy was determined using polarized light microscopy on the thin sections. None of the thin sections contain lamellae. Typical sets consist of $80-90 \%$ quartz, $6-13 \%$ plagioclase, $1-2 \%$ mica, $<1 \%$ chert, $<1 \%$ shale, and $<1 \%$ unidentifiable or highly fractured grains (Table 3-4). Percentages of minerals are generally constant throughout the stratigraphic sequence (Figure 3-7). None of the minerals counted in this study significantly increase or decrease with depth $(\mathrm{P}>0.050)$. Quartz is more abundant between 6 to 9 meters in the middle of the stratigraphic sequence (Figure 3-8).

Plagioclase decreases between 1 to 9 meters depth in the stratigraphic sequence (Figure 3-9). This relationship is characterized by the ratio of quartz to plagioclase (feldspar), which is higher between 2 to 10 meters depth (Figure 3-10). A greater concentration of quartz indicates highly weathered dune sand. Mica decreases with depth, and chert increases with depth (Figure 3-11). 
Eleven roots were found at depth during grain counts: two roots at 2 to 3 meters, two roots at 6 to 7 meters, one root at 7 to 8 meters, five roots at 9 to 10 meters, and one root at 10 to 11 meters (Table 3-5). Aside from the grain counts, two modern root features with mycorrhizal sheaths (FitzPatrick, 1993) as well as a modern root channel were found at 0 to 2 meters depth (Figure 3-12). Fossilized fungal hyphae were discovered between sand grains at 9 to 10 meters depth (Figure 3-13). Select photographs of minerals and features of the thin sections under microscopy are provided in Appendix B.

Table 3-4. Sand mineralogy of thin sections. All samples were averaged except for 0 to 1 meters, which is a single sample set because of sample loss.

\begin{tabular}{|c|c|c|c|c|c|c|c|c|}
\hline \multirow{2}{*}{$\frac{\text { Depth }}{\mathrm{m}}$} & \multirow[t]{2}{*}{ Sampling Interval } & \multicolumn{6}{|c|}{ Thin Section Grain Count \% } & \multirow{2}{*}{$\mathrm{Q}: \mathrm{P}$} \\
\hline & & $\mathrm{Q}$ & $\mathrm{P}$ & Mica & $\mathrm{C}$ & $\mathrm{S}$ & $\mathrm{U}$ or Fr & \\
\hline $0-1$ & $\mathrm{H}$ & 84.08 & 13.69 & 1.27 & 0.32 & 0.64 & 0.00 & 6.14 \\
\hline $1-2$ & G & 86.66 & 9.60 & 2.98 & 0.15 & 0.30 & 0.30 & 9.03 \\
\hline $2-3$ & $\mathrm{~F}$ & 84.90 & 9.99 & 3.68 & 0.31 & 0.95 & 0.16 & 8.50 \\
\hline \multicolumn{9}{|l|}{$3-4$} \\
\hline \multicolumn{9}{|l|}{$4-5$} \\
\hline $5-6$ & I & & & & & & & \\
\hline $6-7$ & $\mathrm{E}$ & 90.24 & 6.72 & 1.60 & 0.64 & 0.80 & 0.00 & 13.43 \\
\hline $7-8$ & $\mathrm{D}$ & 88.66 & 7.60 & 2.49 & 0.62 & 0.62 & 0.00 & 11.67 \\
\hline $8-9$ & $\mathrm{C}$ & 89.41 & 8.43 & 1.00 & 1.04 & 0.12 & 0.00 & 10.61 \\
\hline $9-10$ & B & 82.53 & 11.91 & 2.12 & 2.37 & 0.78 & 0.29 & 6.93 \\
\hline $10-11$ & A & 85.74 & 11.47 & 1.86 & 0.15 & 0.31 & 0.47 & 7.48 \\
\hline $11.3-13$ & Colluvial Apron & & & & & & & \\
\hline
\end{tabular}




\section{Thin Section Grain Counts (\%)}

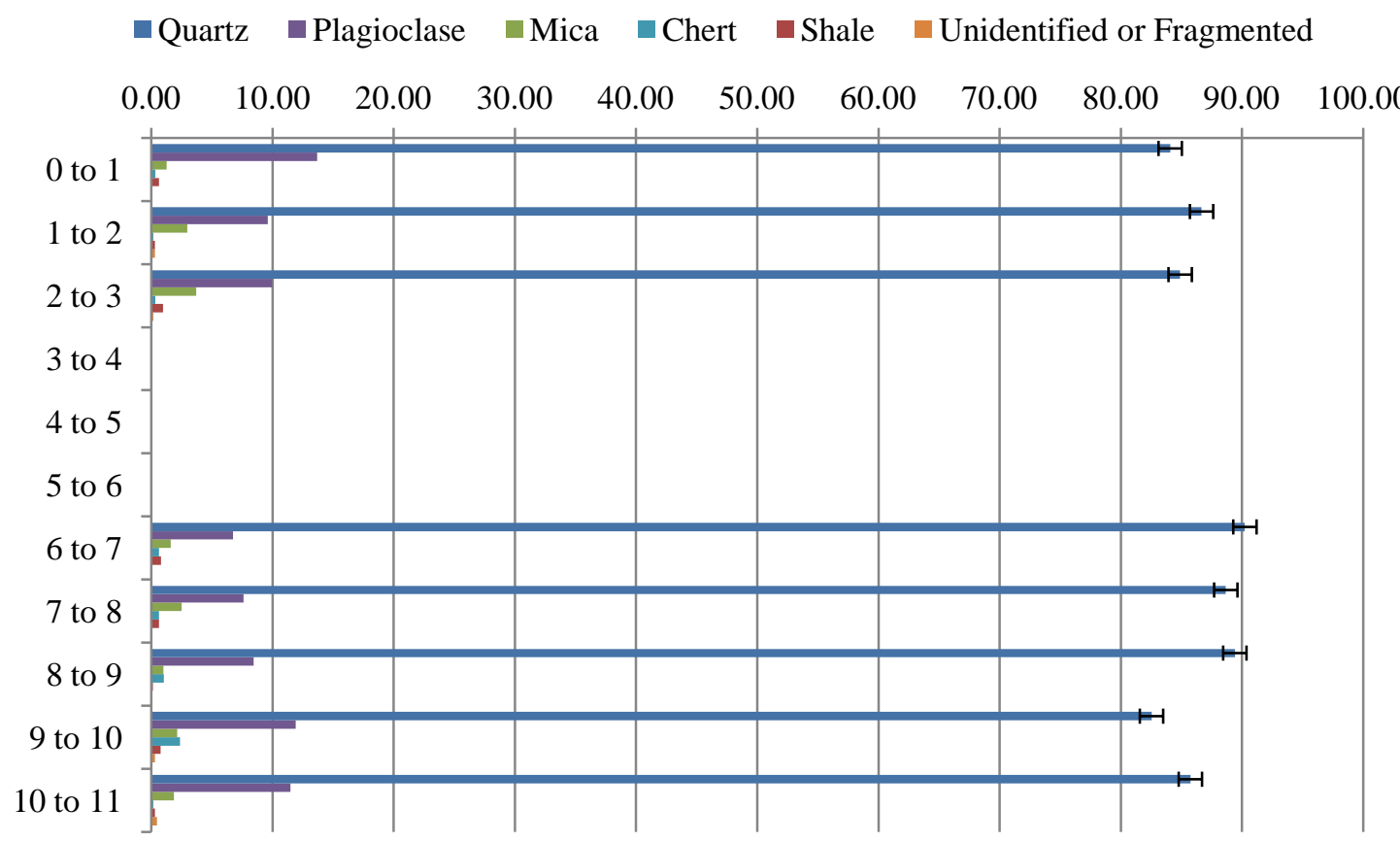

Figure 3-7. Sand mineralogy of stratigraphic sequence. Depth is in meters, error bars display standard error, and $\mathrm{x}$-axis is in percent.

Thin Section Grain Counts (\%)

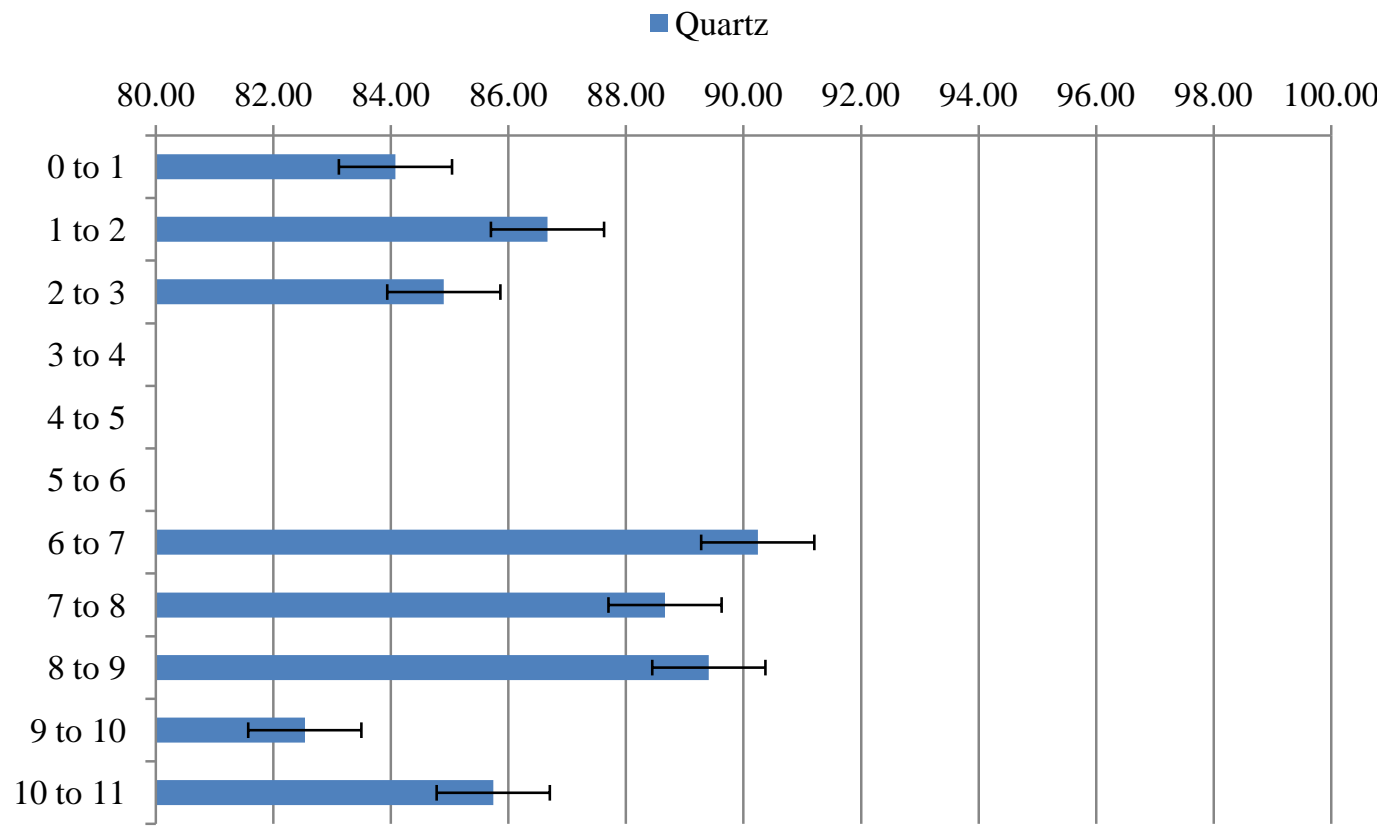

Figure 3-8. Selected sand mineralogy of quartz in stratigraphic sequence. Depth is in meters, error bars display standard error, and $\mathrm{x}$-axis is in percent. 


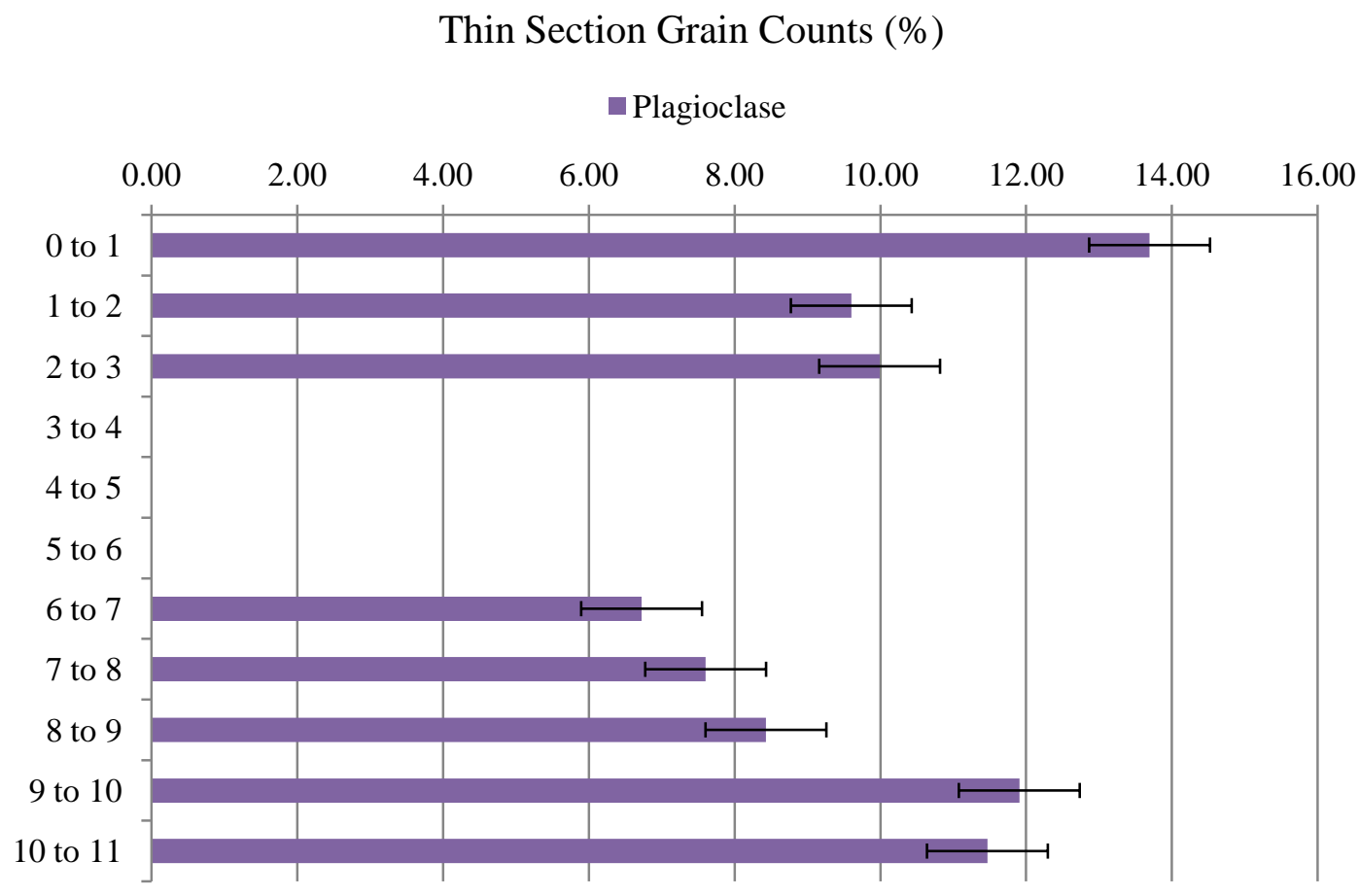

Figure 3-9. Selected sand mineralogy of plagioclase in stratigraphic sequence. Depth is in meters, error bars display standard error, and $\mathrm{x}$-axis is in percent.

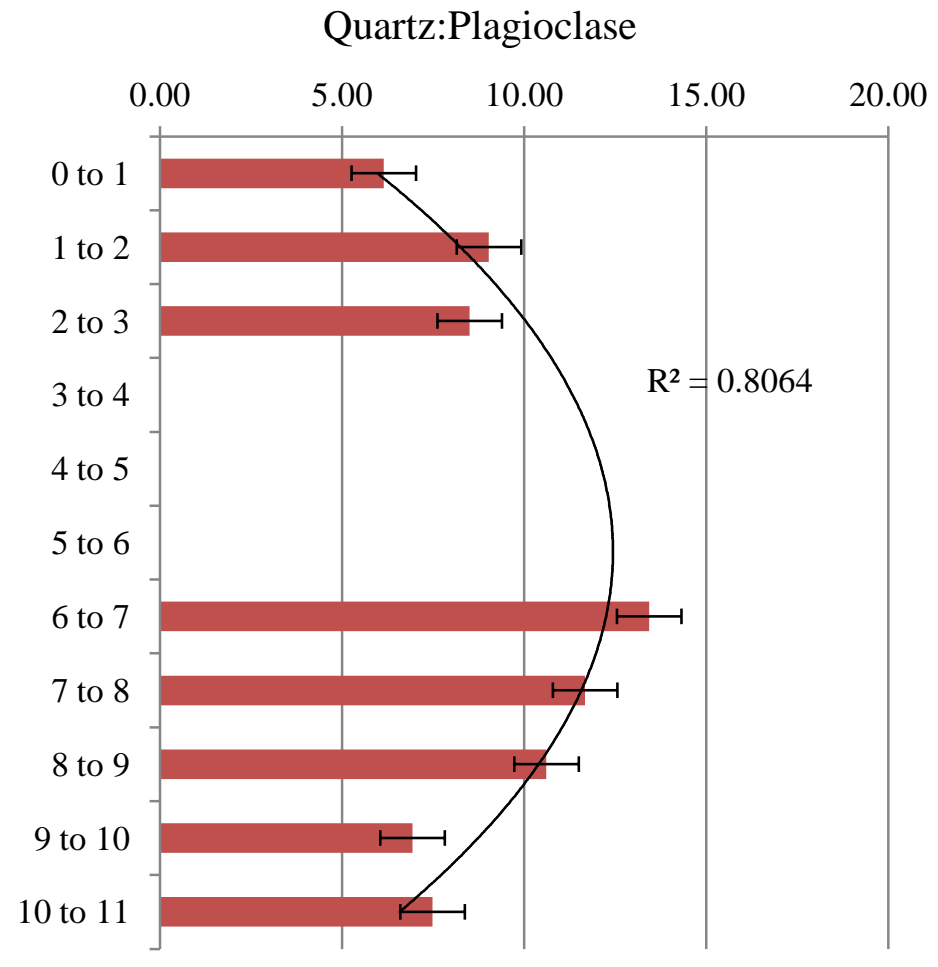

Figure 3-10. Quartz to plagioclase ratio in stratigraphic sequence. Depth is in meters and error bars display standard error. 


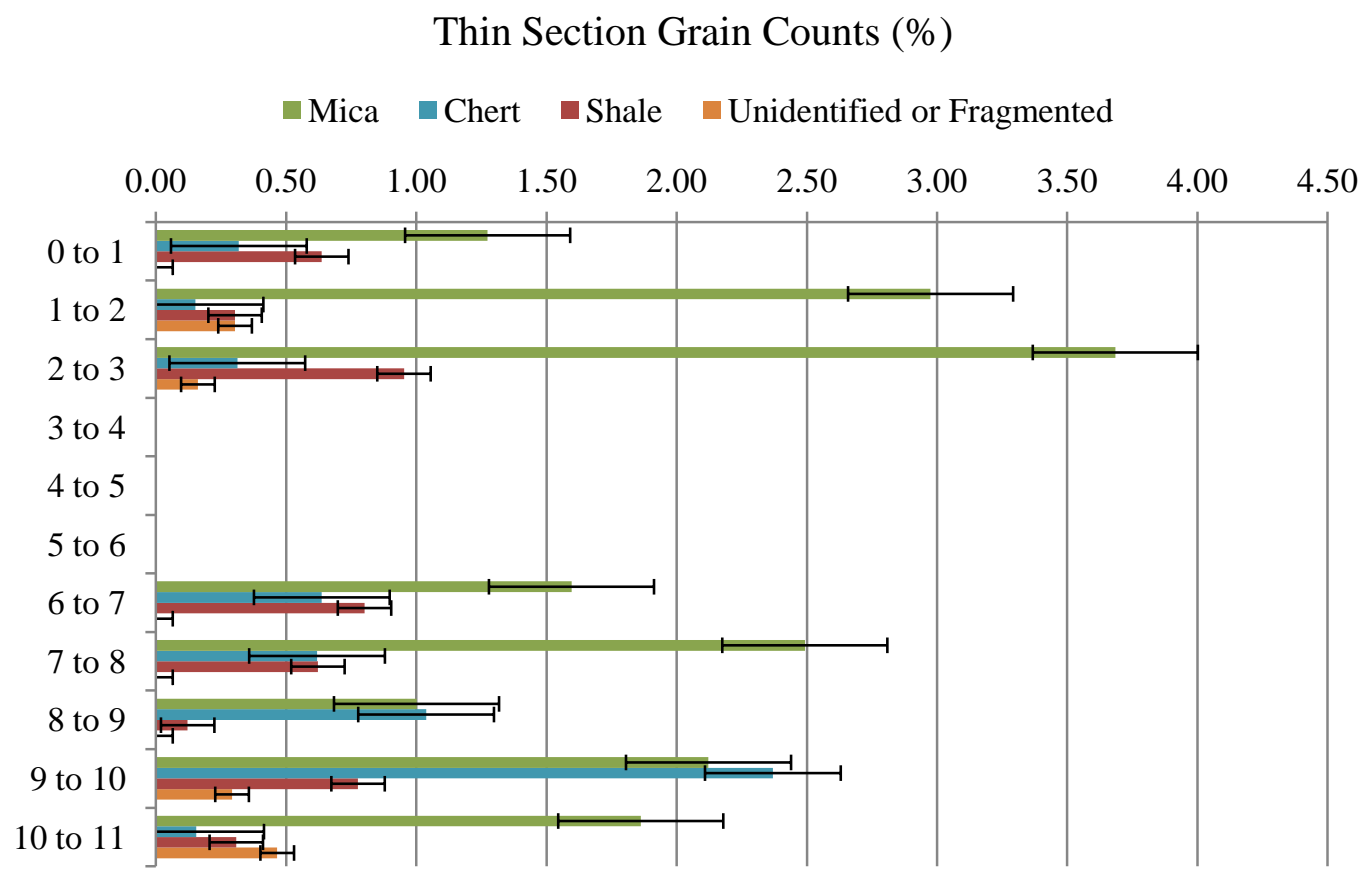

Figure 3-11. Selected sand mineralogy of minor grains in stratigraphic sequence. Depth is in meters, error bars display standard error, and x-axis is in percent. Quartz and plagioclase omitted from this figure to better depict concentrations of minor grains.

Table 3-5. Root counts in thin sections. Total root count includes roots and root channels discovered independent of the grain count.

\begin{tabular}{ccc}
\hline Depth & Roots Identified During Grain Count & Total Roots + Channels \\
\cline { 1 - 2 } $\mathrm{m}$ & 0 & 3 \\
\hline-1 & 0 & 1 \\
$2-2$ & 2 & 2 \\
$3-4$ & & \\
$4-5$ & & \\
$5-6$ & & \\
$6-7$ & 2 & 2 \\
$7-8$ & 1 & 1 \\
$8-9$ & 0 & 0 \\
$9-10$ & 5 & 5 \\
$10-11$ & 1 & 1 \\
$11.3-13$ & Colluvial Apron & \\
\hline
\end{tabular}




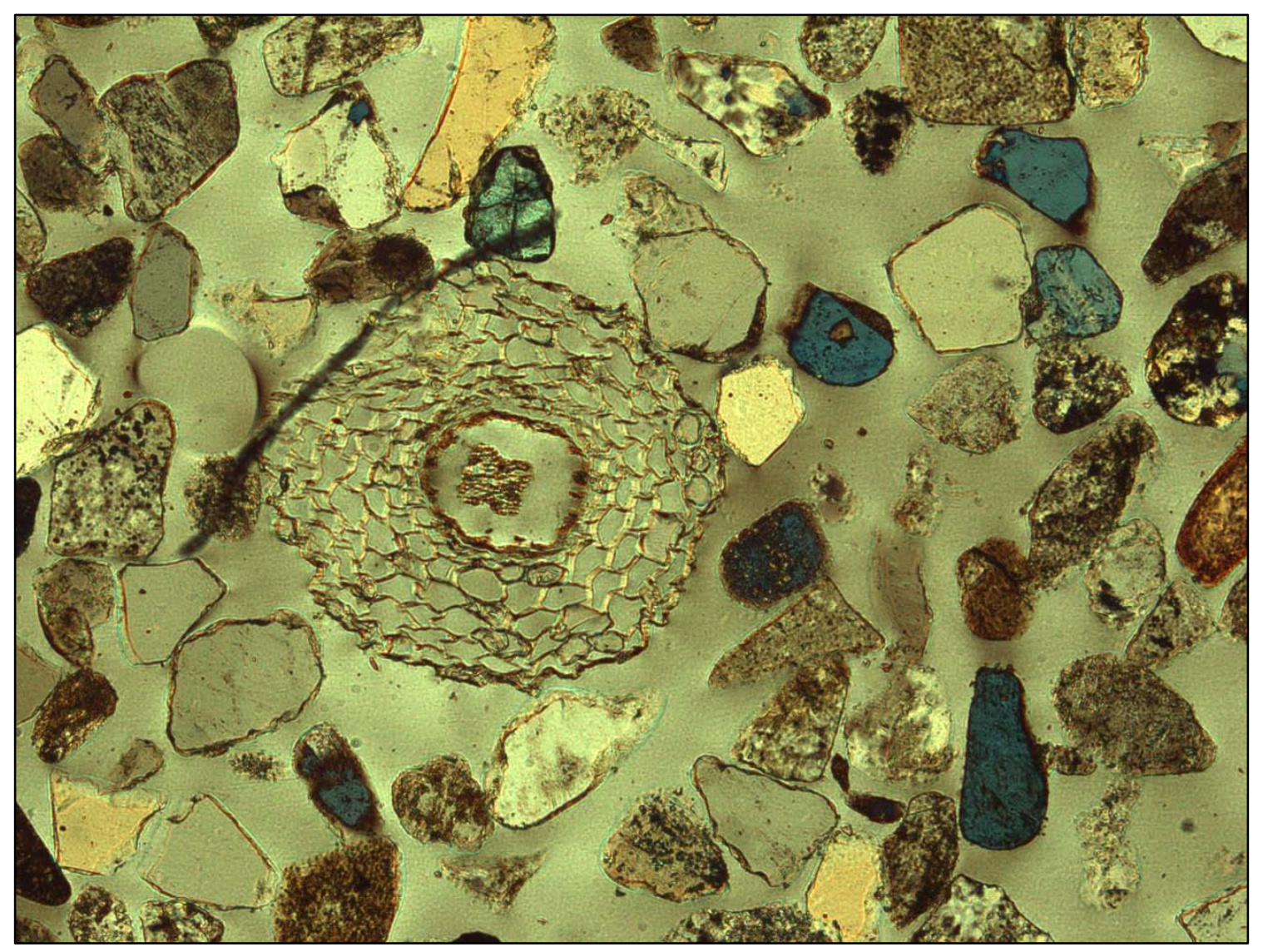

Figure 3-12. Cross section of root covered by mycorrhizal sheath (FitzPatrick, 1993) located 0 to 1 meters depth under cross-polars at 40X magnification (Photomicrograph credit: Lyssa A. Cousineau). 


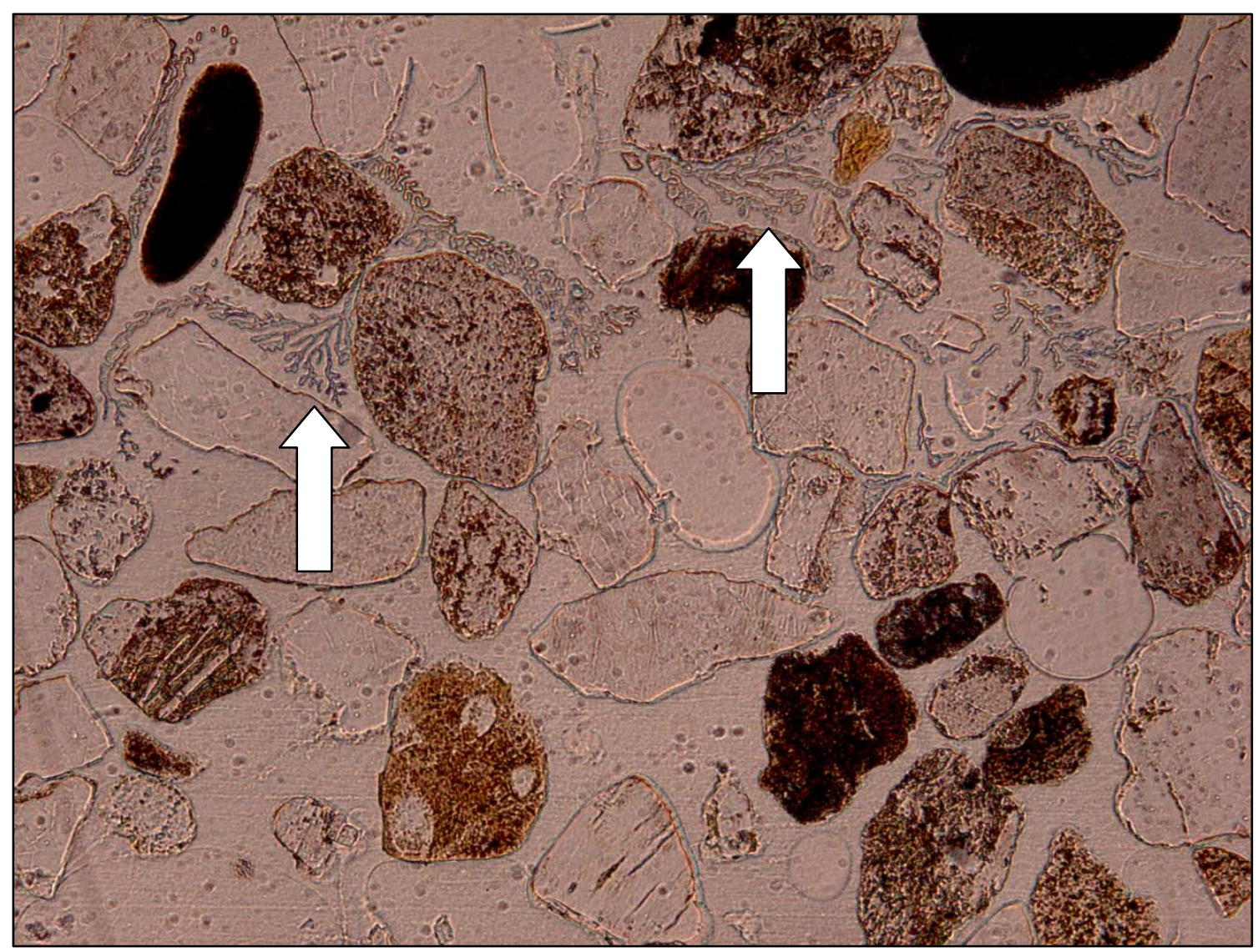

Figure 3-13. Filamentous, branching structures of fungal hyphae between grains located 9 to 10 meters depth under plane polarized light at 40X magnification (Photomicrograph credits: Lyssa A. Cousineau and Adrian Gallo).

\section{Selective Dissolution}

Pedogenic iron oxides are present in the stratigraphic sequence. Ammonium oxalate in the dark $\left(\mathrm{Fe}_{\mathrm{o}}\right)$ extracts poorly crystalline iron oxides such as ferrihydrite, and citrate-bicarbonate-dithionite $\left(\mathrm{Fe}_{\mathrm{d}}\right)$ extracts total pedogenic iron oxides such as hematite and goethite. Generally, iron oxide values correlate with values previously determined from another study near the current study site (Moody and Graham, 1994 and 1995).

Regression analysis of poorly crystalline iron oxide $\left(\mathrm{Fe}_{\mathrm{o}}\right)$ content indicates that poorly crystalline iron oxide content significantly decreases by linear regression with depth $(0<\mathrm{P}<0.000)$ (Table 3-6 and Figure 3-14). Poorly crystalline iron oxide content decreases by $0.048789 \mathrm{~g} / \mathrm{kg}$ per one meter. 
Regression analysis of total pedogenic iron oxide $\left(\mathrm{Fe}_{\mathrm{d}}\right)$ content indicates that total pedogenic iron oxide content significantly decreases by linear regression with depth $(0<\mathrm{P}<0.000)$ (Table 3-6 and Figure 3-14). Total pedogenic iron oxide $\left(\mathrm{Fe}_{\mathrm{d}}\right)$ content decreases by $0.08465 \mathrm{~g} / \mathrm{kg}$ per one meter.

Grouping information using the Tukey method with 95\% confidence is presented in Table 3-7. Grouping information highlights means that are significantly different from each other. For example, grouping A is significantly different than grouping B or grouping C. Means with two groupings are not statistically different from either grouping listed.

There is a decrease in pedogenic iron oxide content at 6 to 11 meters depth (Figure 3-15). The content of pedogenic iron oxides is lowest in concentration at 6 to 7 meters and 10 to 11 meters. Thus, the ratio of poorly crystalline iron oxide $\left(\mathrm{Fe}_{\mathrm{o}}\right)$ content to total pedogenic iron oxide $\left(\mathrm{Fe}_{\mathrm{d}}\right)$ content decreases significantly with depth (Figure 316). $\mathrm{Fe}_{\mathrm{o}} / \mathrm{Fe}_{\mathrm{d}}$ is a relative dating tool. A lower ratio suggests the presence of an older soil. Therefore, age of the stratigraphic sequence increases with depth. The younger iron oxides are more abundant between 0 to 6 meters depth and the older iron oxides are more abundant between 6 to 11 meters depth. 
Table 3-6. Selective dissolution chemical data for stratigraphic sequence.

\begin{tabular}{ccccc}
\hline Depth & Sampling Interval & $\mathrm{Fe}_{\mathrm{o}}$ & $\mathrm{Fe}_{\mathrm{d}}$ & $\mathrm{Fe}_{\mathrm{o}} / \mathrm{Fe}_{\mathrm{d}}$ \\
\hline $\mathrm{m}$ & & \multicolumn{4}{c}{$\mathrm{g} \mathrm{kg}^{-1}$} \\
\hline $0-1$ & $\mathrm{H}$ & 0.71 & 2.51 & 0.28 \\
$1-2$ & $\mathrm{G}$ & 0.51 & 2.26 & 0.23 \\
$2-3$ & $\mathrm{~F}$ & 0.70 & 2.69 & 0.26 \\
$3-4$ & & & & \\
$4-5$ & & & & \\
$5-6$ & $\mathrm{I}$ & 0.66 & 2.70 & 0.24 \\
$6-7$ & $\mathrm{E}$ & 0.35 & 1.67 & 0.21 \\
$7-8$ & $\mathrm{D}$ & 0.23 & 2.00 & 0.12 \\
$8-9$ & $\mathrm{C}$ & 0.27 & 2.10 & 0.13 \\
$9-10$ & $\mathrm{~B}$ & 0.31 & 2.10 & 0.15 \\
$10-11$ & A & 0.20 & 1.34 & 0.15 \\
$11.3-13$ & Colluvial Apron & & & \\
\hline
\end{tabular}

$\mathrm{Fe}_{\mathrm{o}}=$ ammonium oxalate in the dark, $\mathrm{Fe}_{\mathrm{d}}=$ sodium citrate-bicarbonate-dithionite, $\mathrm{Fe}_{\mathrm{o}}: \mathrm{Fe}_{\mathrm{d}}=$ crystalline iron oxides (Bascomb, 1968)

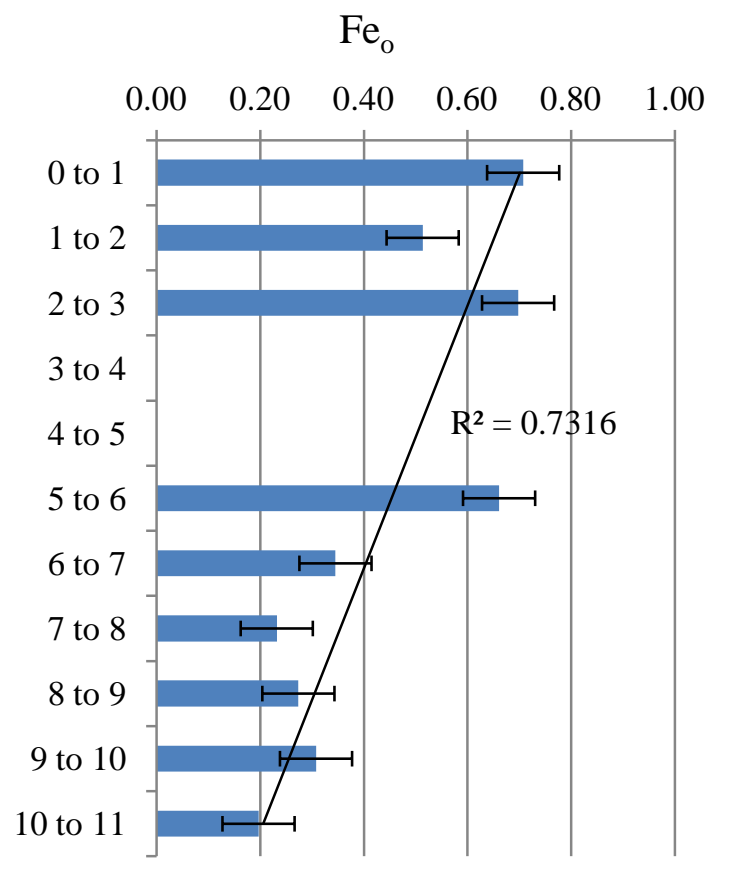

Figure 3-14. Poorly crystalline iron oxides $\left(\mathrm{Fe}_{\mathrm{o}}\right)$ of stratigraphic sequence. Depth is in meters and error bars display standard error. 
Table 3-7. Grouping information using the Tukey method with 95\% confidence for total pedogenic iron oxides $\left(\mathrm{Fe}_{\mathrm{d}}\right)$ and poorly crystalline iron oxides $\left(\mathrm{Fe}_{\mathrm{o}}\right)$.

\begin{tabular}{rrrrr} 
& \multicolumn{2}{c}{$\mathrm{Fe}_{\mathrm{o}}\left(\mathrm{g} \mathrm{kg}^{-1}\right)$ vs. Depth $(\mathrm{m})$} & \multicolumn{2}{c}{$\mathrm{Fe}_{\mathrm{d}}\left(\mathrm{g} \mathrm{kg}^{-1}\right)$ vs. Depth $(\mathrm{m})$} \\
\hline Depth (mean) & \multicolumn{1}{c}{ Mean } & \multicolumn{1}{c}{ Grouping } & Mean & Grouping \\
\hline 0.5 & 0.7 & A & 2.5 & $\mathrm{~A}$ \\
1.5 & 0.5 & $\mathrm{~B}$ & 2.3 & $\mathrm{AB}$ \\
2.5 & 0.7 & $\mathrm{~A}$ & 2.7 & $\mathrm{~A}$ \\
6.5 & 0.3 & $\mathrm{C}$ & 1.7 & $\mathrm{BC}$ \\
7.5 & 0.2 & $\mathrm{CD}$ & 2.0 & $\mathrm{ABC}$ \\
8.5 & 0.3 & $\mathrm{CD}$ & 2.1 & $\mathrm{AB}$ \\
9.5 & 0.3 & $\mathrm{CD}$ & 2.1 & $\mathrm{AB}$ \\
10.5 & 0.2 & $\mathrm{D}$ & 1.3 & $\mathrm{C}$ \\
\hline
\end{tabular}

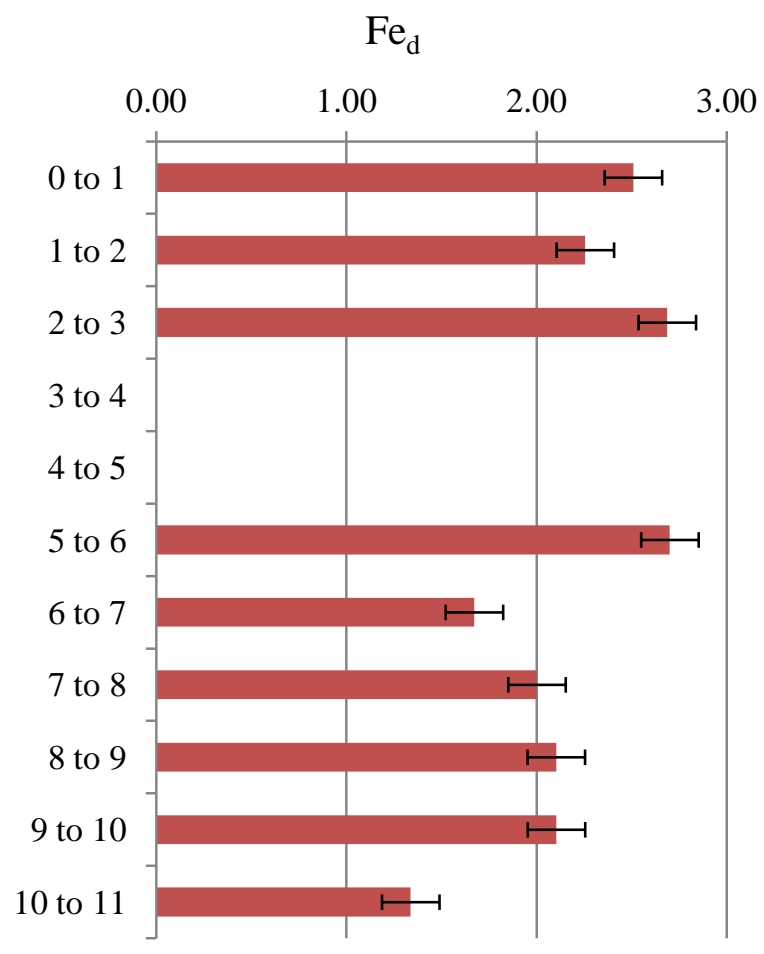

Figure 3-15. Total pedogenic iron oxides $\left(\mathrm{Fe}_{\mathrm{d}}\right)$ of stratigraphic sequence. Depth is in meters and error bars display standard error. 


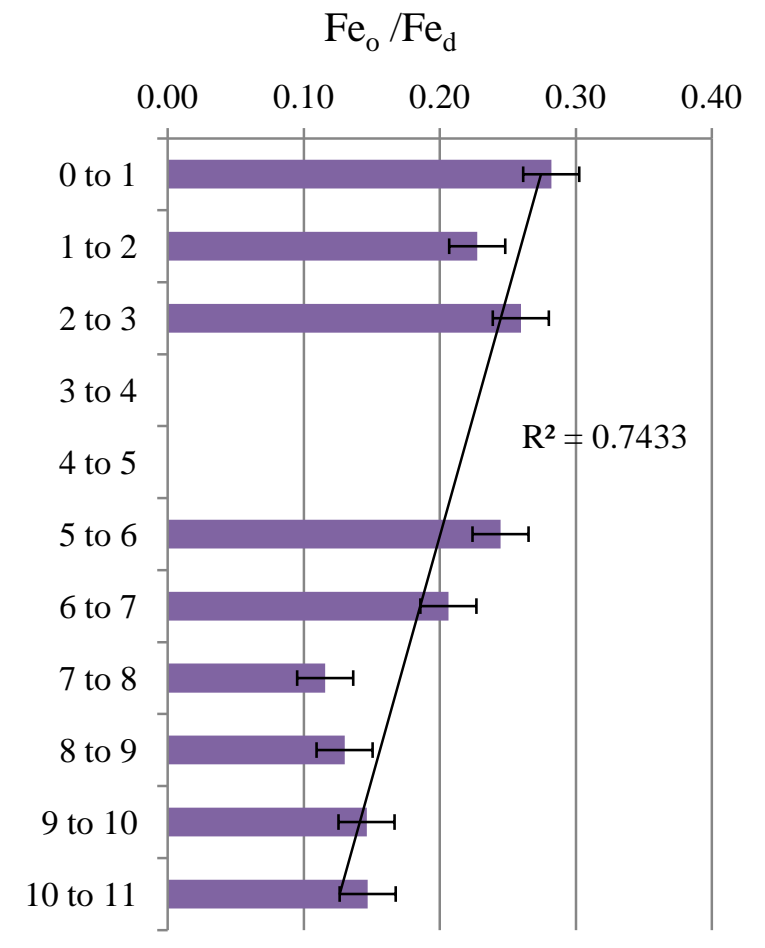

Figure 3-16. Ratio of poorly crystalline iron oxides $\left(\mathrm{Fe}_{\mathrm{o}}\right)$ to total pedogenic iron oxides $\left(\mathrm{Fe}_{\mathrm{d}}\right)$ of stratigraphic sequence. Depth is in meters and error bars display standard error. 


\section{DISCUSSION}

\section{Modern Soil Development}

Total carbon significantly decreases with depth (Table 3-1; Figure 3-2), indicating that 0 to 1 meters of the stratigraphic sequence are a habitat for flora and fauna. In addition, roots covered in mycorrhizal sheaths (Figure 3-12) and modern root channels were found only at 0 to 2 meters depth. These chemical and physiological features indicate that soil is actively being produced within the top two meters of the dune.

\section{Lamellae}

Initial lamella form when clay is transported by a wetting front at or near saturation. When the clay drops out of suspension, it settles on a stratigraphic bedding plane. The increase in clay on the stratigraphic bedding plane leads to a decrease in pore space. The decrease in pore space eventually creates a clay barrier where additional clay is deposited on top of the initial clay lamella. This process continually repeats itself, and lamellae are formed. However, the wetting front is not perfectly horizontal and clays from the lower lamellae are eventually eroded away.

Because illuvial lamellae are abundant throughout the stratigraphic sequence, it can be concluded that pedogenesis occurs on a wetting front that spans the entire stratigraphic sequence studied. An increase in clay between 5 to 7 meters depth (Table 32 and Figure 3-6) confirms the downward movement of lamellae, and validates the concentration of clay content near the center of the sequence (Schaetzl, 2001; Soil Survey Staff, 1999). Schaetzl (2001) attributes the loss of clay in the uppermost horizons of a sequence to eluviation of clay, which is the source of clay in lamellae in the studied sequence. 
The concentration of clay near the center of the sequence studied is indicative of lamellae development. The Soil Survey Staff (1999) states that clay bands are termed "lamellae" only after being affected by pedogenesis. The development of lamellae requires a wetting front. The quartz-rich stratigraphic sequence studied drains easily and thus provides an environment conducive to lamellae development.

\section{Pedogenic Iron Oxides}

According to previous studies, iron oxide content increases with age and depth of a stratigraphic sequence (Miles and Franzmeier, 1981; Moody and Graham, 1995 and 1997; Sauer et al. 2010; Tsai et al., 2007; Wagner et al., 2007). In this study, poorly crystalline iron oxide $\left(\mathrm{Fe}_{\mathrm{o}}\right)$ content and total pedogenic iron oxide $\left(\mathrm{Fe}_{\mathrm{d}}\right)$ content significantly decrease with depth (Figure 3-14 and 3-15), so the ratio of poorly crystalline iron oxide $\left(\mathrm{Fe}_{\mathrm{o}}\right)$ content to total pedogenic iron oxide $\left(\mathrm{Fe}_{\mathrm{d}}\right)$ content also significantly decreases with depth (Figure 3-16).

Values and trends in this study corresponded closely with previously obtained values and trends for a nearby study site (Moody and Graham, 1994 and 1995). Moody and Graham (1994 and 1995) attributed the decrease in iron oxides in their study to an unknown mechanism that prevented poorly crystalline iron oxides (ferrihydrite) from transforming into crystalline hematite or goethite. Ferrihydrite is not as stable as goethite or hematite. It may be that the ferrihydrite is converting to better crystalline iron oxides, hematite and goethite or both.

\section{Paleosol}

A paleosol may be present at 9 to 10 meters depth. Certain morphologic and mineralogic features indicate the presence of this paleosol. Using grain counts, Little et 
al. (1978) found that weathered quartz grains are more prevalent in older, developed dune sands. This is because feldspars, chert, mica, and other minor minerals in a stratigraphic sequence weather more rapidly than quartz. Quartz is least prevalent between 0 to 2 meters, where modern soil is developing (Figure 3-8). Similarly, there is little quartz present between 9 to 10 meters relative to the general increase of quartz with depth. The ratio of plagioclase to quartz (Figure 3-10) suggests that the shallow intervals (0 to 2 meters) of the sequence and deeper intervals (8 to 11 meters) of the sequence have weathered the least. This may be because weathering is part of soil development.

Subrounded grains are generally more weathered than subangular grains. The quartz at 9 to 10 meters depth is predominantly subrounded, as opposed to subangular. On the other hand, the low quartz to plagioclase ratio at 9 to 10 meters depth indicates that interval is less weathered than an interval with a high quartz to plagioclase ratio.

Soil mineralogy and micromorphology provide the strongest case for a paleosol. Five roots are present between 9 and 10 meters (Table 3-5), more than twice the number of roots found in any other interval. Roots located deeper than 0 to 3 meters are unlikely modern, because vegetation is not present at these depths. The ice plant covering the surface of the dune has a shallow root system so it is very unlikely that the root channels and fungal hyphae at this depth are associated with modern plants or modern soil ecology.

Fossilized fungal hyphae were found between grains at 9 to 10 meters (Figure 313). Fungal hyphae are some of the first indicators of soil development. Because of the depth these structures and the relative shallow root structure of present flora (ice plant), it is likely that the fungal hyphae are fossilized. In order to fossilize fungal hyphae, the sand 
dune must have been rapidly covered. Since silt and clay are not present in any large quantities throughout the stratigraphic sequence (Figure 3-6), and the surrounding dunes appear to be quartz-dominated as well, it is likely that the soil was rapidly covered by a newly developing dune or water during a relatively quick rise in sea level (transgression).

An increase in nitrogen content (Table 3-1; Figure 3-3) at 9 to 10 meters depth correlates with the presence of fossilized fungal hyphae. Nitrogen is commonly found in amino acids. The primary sources of amino acids in soils and sediments occur as peptides and come from microbes (Curry et al., 1994). Typically, inclusions of nitrogen from something other than modern microbial activity are derived from intracrystalline amino acids from geologic fossils (Abelson, 1959).

Previous studies have shown that an increase in nitrogen can be an indicator for paleosols located in stratigraphic sequences (Calderoni and Schnitzer, 1984; Curry et al., 1994; Goh, 1972). Curry et al. (1994) confirms that some of the paleosols in their study date to about 30-ka. It is possible that nitrogen is encased in the fossilized fungal hyphae found at 9 to 10 meters in the stratigraphic sequence studied. The fossils released their nitrogen during combustion in the VarioMax CNS analyzer. Thus, a significant increase in nitrogen is present at 9 to 10 meters depth.

\section{Relative Dating of Paleosol}

Sands collect on top of marine wave-cut platforms during stable periods of eustatic sea level lowstands because sands are no longer being swept away by tides and currents into deeper ocean water and are exposed to drying and wind. The last major lowstand prior to the modern period occurred between 75-ka and 12-ka (Figure 1-2). Previous studies have indicated that the youngest terraces formed during three lowstands: 
12-ka to 15-ka (CA State Parks, 1988; Moody and Graham, 1995), 27-ka (Moody and Graham, 1995), and 48-ka (Moody and Graham, 1995).

Orme (2005) determined that the active dunes are <200 BP, the younger parabolic and lobate dunes are $\leq 1730 \mathrm{BP}$, the older parabolic dunes are less than $\leq 4160 \mathrm{BP}$, and the youngest paleodunes were deposited around 27-ka (Table 1-1). The older parabolic dunes correlate with surface dune deposits located near the study site that were recently dated between 3568 BP and 3830 BP (Jack Meyer from Far Western Anthropological Research Group, Inc., personal communication, 2012). The youngest paleodunes were deposited between 15-ka and 30-ka, which generally corresponds with the 27-ka lowstand and terrace development.

Dunes that were formed during the last drop in sea level have since partially eroded because the last eustatic sea level lowstand spanned a relatively short period of time and depositional layers were subsequently thin (Hanson et al., 1994; Orme 1990). The last period of stability was about 12-ka, so a soil developed during this timeframe may have been eroded away and is no longer present as a paleosol in the stratigraphic sequence. As a result, the paleosol noted at 9 to 10 meters in the stratigraphic sequence is likely between 15-ka and 30-ka. A modern dating method, such as optically stimulated luminescence, may confirm this possibility in a future study. 


\section{CONCLUSIONS}

The goal of this study was to assess mineralogy and pedogenic features of sand dunes in a stratigraphic sequence. The purpose was to determine whether these features significantly differ to reflect age differences with depth within the sequence. This was a pilot study so much work can be done to further the development of these findings in the future. A modern dating method, such as optically stimulated luminescence, may confirm the relative dating method used in this study.

Total carbon significantly decreases with depth and soil age (Table 3-1; Figure 32), reflecting the active development of modern soils in the upper three meters of the stratigraphic sequence. Certain morphological and mineralogic features, including an increase in nitrogen content due to the presence of fossilized fungal hyphae (Figure 3-13), a decrease in quartz grains relative to plagioclase (Figures 3-8 and 3-10), and a decrease in $\mathrm{pH}$ (Figure 3-1) indicate that a paleosol may be preserved at 9 to 10 meters depth. Using relative dates compiled from previous research, the soil may have developed as long ago as 15-ka to 30-ka. The soil developed after sand was deposited on top of the wave-cut platform during a eustatic sea level lowstand. Sand was deposited because during a lowstand the previous shoreline is no longer eroded by ocean tides and currents. In general, the presence of fossils (Figure 3-13) within the paleosol suggests that the soil may have been rapidly covered.

Certain morphologic and mineralogic trends, such as total carbon, nitrogen, mineral concentrations, clay content, and evidence of fossils reflect age differences with depth within the sand dune sequence studied. Because of the unique episodic periods of deposition and soil development on wave-cut platforms, these features are concentrated at 
select intervals of a stratigraphic sequence and can provide valuable insight into prehistoric and historic climatic conditions as well as ancient soil development.

Dune complexes of marine terraces are known for their dynamism. But dunes also preserve periods of climatic stability with surprising resilience. This resilience is advantageous to earth scientists and archaeologists. Subtle changes in morphology and mineralogy reveal surprisingly detailed information about modern soil development, the presence of paleosols, as well as characteristics of sea level regressions and transgressions and the environments to which they contribute. By applying this knowledge to future paleo-studies and archaeological sites in the region, scientists can gain a better understanding of the environment in which they work. 


\section{LIST OF REFERENCES}

Abelson, P.H. 1959. Geochemistry of organic substances. p. 79-103. In P.H. Abelson (ed.) Research in Chemistry. Wiley, New York.

Aniku, J.R.F. and M.J. Singer. 1990. Pedogenic iron oxide trends in a marine terrace chronosequence. Soil Sci. Soc. Am. J. 54:147-152.

Bascomb, C.L. 1968. Distribution of pyrophosphate-extractable iron and organic carbon in soils of various groups. J. Soil Sci. 19:251-268.

Bischoff, James L. and Robert J. Rosenbauer. 1981. Uranium series dating of human skeletal remains from the Del Mar and Sunnyvale sites, California. Science 213(4511):1003-1005.

Brady, Karen. 1978. Some soil relationships of the Morro Bay sand dunes. MS thesis (Agric.). CA Polytechnic State University, San Luis Obispo, California.

Calderoni, G. and M. Schnitzer. 1984. Nitrogen distribution as a function of radiocarbon age in paleosol humic acids. Org. Geochem. 5(4):203-209.

California Department of Water Resources Southern District. 2002. Water resources of the Arroyo Grande - Nipomo Mesa, 2002 [Online]. Available at http://www.dpla.water.ca.gov/sd/water_quality/arroyo_grande/arroyo_grandenipomo_mesa.html (verified 15 Mar. 2012). California Department of Water Resources, Sacramento, CA.

California Soil Resource Lab. 2011. SoilWeb: An online soil survey browser [Online]. Available at http://casoilresource.lawr.ucdavis.edu/drupal/node/902 (verified 3 Mar. 2011). University of CA Davis, Davis, CA.

California State Parks and Recreation Commission. 1988. Montaña de Oro State Park: General plan [Online]. Available at http://www.parks.ca.gov/pages/21299/files/441.pdf (verified 26 Jan. 2012). CA State Parks and Recreation Commission, Sacramento, CA.

Carter, R.W.G., K.F. Nordstrom, and N.P. Psuty. 1990. Chapter one: The study of coastal dunes. p. 1-11. In Nordstrom, Karl, Norbert Psuty, and Bill Carter. (eds.) Coastal Dunes: Form and Process. John Wiley \& Sons Ltd, Chichester, England.

Cleveland, G.B. 1978. Geologic map of the Pt. Buchon area, San Luis Obispo County, California, with summary comments. Open-File Report 78-17 LA, 6 p. CA Division of Min. and Geol. 
Courchesne, F. and M.-C. Turmel. 2008. Extractable Al, Fe, Mn, and Si. p. 307-315. In Carter, M.R. and E.G. Gregorich. (eds.) Soil Sampling and Methods of Analysis. $2^{\text {nd }}$ ed. CRC Press, Boca Raton, FL.

Curry, Gordon B., Benny K.G. Theng, and Honghan Zheng. 1994. Amino acid distribution in a loess-palaeosol sequence near Luochuan, Loess Plateau, China. Org. Geochem. 22(2):287-298.

Fairbanks, H.W. 1904. Description of the San Luis Quadrangle: Geologic atlas of the United States. US Geol. Survey, San Luis Folio, California, No. 101.

Fey, M.V. and J. LeRoux. 1977. Properties and quantitative estimation of poorly crystalline components in sesquioxidic soil clays. Clays Clay Miner. 25:285-294.

FitzPatrick, E.A. 1993. Soil Microscopy and Micromorphology. John Wiley \& Sons Ltd, Chichester, England.

Gee, G.W. and J.W. Bauder. 1986. Particle-size analysis. p. 383-411. In A. Klute (ed.) Methods of Soil Analysis, Part 1. Physical and Mineralogical Methods. Agron. Monograph no. 9. $2^{\text {nd }}$ ed. ASA and SSSA, Madison, WI.

Gibbard, P. and T. van Kolfschoten. 2004. Chapter 22: The Pleistocene and Holocene epochs. In Gradstein, F.M., James G. Ogg, and A. Gilbert Smith. A Geologic Time Scale 2004. Cambridge University Press, Cambridge, England.

Gibson, R.O. 1981. Cultural resource test program at SLO 978, Morro Bay, San Luis Obispo County, California. Rept. to US Army Corps of Engineers, Los Angeles District.

Goh, K.M. 1972. Amino acid levels as indicators of paleosols in New Zealand soil profiles. Geoderma 7(1-2):33-47.

Graham, R.C. and A.T. O’Geen. 2010. Soil mineralogy trends in California landscapes. Geoderma 154:418-437.

Hall, C.A., Jr. 1973. Geologic map of the Morro Bay south and Port San Luis quadrangles. US Geol. Survey Map, MF-511. San Luis Obispo, CA.

Hanson, Kathryn L., John R. Wesling, William R. Lettis, Keith I. Kelson, and Lili Mezger. 1994. Correlation, ages, and uplift rates of Quaternary marine terraces: South-central coastal California. p. 45-71. In Alterman, I.B., R.B. McMullen, L.S. Cluff, and D.B. Slemmons. (eds.) Seismotectonics of the Central California Coast Ranges. Geol. Soc. Am. Spec. Pap. 292. Geol. Soc. Am., Boulder, CO. 
Hodges, S.C. and L.W. Zelazny. 1980. Determination of noncrystalline soil components by weight difference after selective dissolution. Clays Clay Miner. 28:35-42.

Jackson, M.L., C.H. Lim, and L.W. Zelazny. 1986. Oxides, hydroxides, and aluminosilicates. p. 101-150. In A. Klute (ed.) Methods of Soil Analysis, Part 1. Physical and Mineralogical Methods. Agron. Monograph no. 9. $2^{\text {nd }}$ ed. ASA and SSSA, Madison, WI.

Johnson, D.L., D.N. Johnson, D.W. Benn, and E.A. Bettis III. 2008. Deciphering complex soil/site formation in sands. Geomorphology 101:484-496.

Keller, Margaret A. 1992. Field guide to the upper Miocene siliceous coastal sequence of Montaña de Oro State Park, California. p. 67-80. In Schwalbach, Jon R. and Kevin M. Bohacs. (eds.) Sequence Stratigraphy in Fine-grained Rocks: Examples from the Monterey Formation. Soc. Sed. Geol. Santa Fe Springs, CA.

Kroetsch, D. and C. Wang. 2008. Particle size distribution. p. 713-725. In Carter, M.R. and E.G. Gregorich. (eds.) Soil Sampling and Methods of Analysis. $2^{\text {nd }}$ ed. CRC Press, Boca Raton, FL.

Little, L.P., T.M. Armitage, and R.J. Gilkes. 1978. Weathering of quartz in dune sands under subtropical conditions in eastern Australia. Geoderma 20:225-237.

Lynn, Warren, J.E. Thomas, and L.E. Moody. 2008. Petrographic microscope techniques for identifying soil minerals in grain mounts. p. 161-190. In Methods of Soil Analysis. Part 5. Mineralogical Methods. SSSA Book Series, no. 5. Madison, WI.

Macphail, Richard I. and Joseph M. McAvoy. 2008. A micromorphological analysis of stratigraphic integrity and site formation at Cactus Hill, an early Paleoindian and hypothesized pre-Clovis occupation in south-central Virginia, USA. Geoarchaeology Int. J. 23(5):675-694.

Mehra, O.P. and M.L. Jackson. 1960. Iron oxide removal from soils and clays by a dithionite-citrate system buffered with sodium bicarbonate. Clays Clay Miner. 7:317-327.

Miles, R.J. and D.P. Franzmeier. 1981. A lithochronosequence of soils formed in dune sand. SSSA J. 45:362-367.

Moody, L.E., and R.C. Graham. 1994. Pedogenic processes in thick sand deposits on a marine terrace. p. 41-55. In D.L. Cremeens et al. (ed.) Whole Regolith Pedology. SSSA Spec. Publ. 34. SSSA, Madison, WI.

Moody, L.E. and R.C. Graham. 1995. Geomorphic and pedogenic evolution in coastal sediments, central California. Geoderma 67:181-201. 
Moody, L.E. and R.C. Graham. 1997. Silica-cemented terrace edges, central California coast. SSSA J. 61:1723-1729.

Muhs, Daniel R. 2012. Last interglacial: Timing and environment (LITE) [Online]. Available at http://esp.cr.usgs.gov/info/lite (verified 15 Mar. 2012). US Geol. Survey, Washington, DC.

NRCS. 2010. Keys to soil taxonomy, eleventh edition [Online]. Available at http://soils.usda.gov/technical/classification/tax_keys/ (verified 16 Mar. 2012). USDA, Washington, DC.

NRCS. 2011. Web soil survey [Online]. Available at http://websoilsurvey.nrcs.usda.gov/app/WebSoilSurvey.aspx (verified 1 Feb. 2011). USDA, Washington, DC.

Ogg, Gabi. 2010. International stratigraphic chart [Online]. Available at http://www.stratigraphy.org/section.php?id=Chart/Time Scale (verified 15 Mar. 2012). Int. Comm. on Stratigraphy.

Orme, Antony R. 2005. The coast from Morro Bay to Point Conception. p. 334-358. In Griggs, Gary B. et al. (eds.) Living with the Changing California Coast. University of California Press, Berkeley, CA.

Orme, A.R. 1990. Chapter fourteen: The instability of Holocene coastal dunes: the case of the Morro Dunes, California. p. 315-333. In Nordstrom, Karl, Norbert Psuty, and Bill Carter. (eds.) Coastal Dunes: Form and Process. John Wiley \& Sons Ltd, Chichester, England.

Pacific Gas and Electric Company. 1973. Section 2.5, Geology and seismology, final safety analysis report, units 1 and 2, Diablo Canyon Site. Docket Nos. 50-275, 50323. US At. Energy Commission, San Francisco, CA.

Pacific Gas and Electric Company. 1988. Final report of the Diablo Canyon long-term seismic program for the Diablo Canyon power plant. Docket Nos. 50-275, 50323. US Nucl. Regulatory Commission, San Francisco, CA.

Page, Benjamin M., Thompson, George A., and Robert G. Coleman. 1998. Late Cenozoic tectonics of the central and southern Coast Ranges of California. GSA Bulletin 110(7):846-876.

Penneck, Dan,Thomas Yates, and Jeff Braidek. 2008. Soil sampling designs. p. 1-13. In Carter, M.R. and E.G. Gregorich. (eds.) Soil sampling and Methods of Analysis. $2^{\text {nd }}$ ed. CRC Press, Boca Raton, FL.

Reheis, Marith C., Richard L. Reynolds, Harland Goldstein, Helen M. Roberts, James C. Yount, Yarrow Axford, Linda Scott Cummings, and Nancy Shearin. 2005. Late 
Quaternary eolian and alluvial response to paleoclimate, Canyonlands, southeastern Utah. Geol. Soc. Am. Bull. 117(7-8):1051-1069.

Rutherford, P.M., W.B. McGill, J.M. Arocena, and C.T. Figueiredo. 2008. Total nitrogen. p. 239-250. In Carter, M.R. and E.G. Gregorich. (eds.) Soil sampling and Methods of Analysis. $2^{\text {nd }}$ ed. CRC Press, Boca Raton, FL.

Sauer, Daniela, Stephen Wagner, Helmut Brückner, Fabio Scarciglia, Giuseppe Mastronuzzi, and Karl Stahr. 2010. Soil development on marine terraces near Metaponto (Gulf of Taranto, southern Italy). Q. Int. 222:48-63.

Schwertmann, U. 1964. Differenzierung der Eisenoxide des Bodens durch photochmische Extraktion mit saurer Ammoniumoxalate-Lösung. Z. Pflanzenernähr. Dueng. Bodenk. 105:194-202.

Schaetzl, Randall J. 2001. Morphologic evidence of lamellae forming from thin, clayey bedding planes in a dune. Geoderma 99:51-63.

Shang, Chao and Lucian W. Zelazny. 2008. Selective dissolution techniques for mineral analysis of soils and sediments. p. 33-80. In Methods of Soil Analysis. Part 5. Mineralogical Methods. SSSA Book Series, no. 5. Madison, WI.

Sherard, J.L., L.P. Dunnigan, and R.S. Decker. 1976. Identification and nature of dispersive soil. J. of the Geotech. Division, A.S.C.E. 102:287-301.

Skjemstad, J.O. and J.A. Baldock. 2008. Total and organic carbon. p. 225-237. In Carter, M.R. and E.G. Gregorich. (eds.) Soil sampling and Methods of Analysis. $2^{\text {nd }}$ ed. CRC Press, Boca Raton, FL.

Soil Survey Division Staff. 1993. Soil survey manual [Online]. Available at http://soils.usda.gov/technical/manual/ (verified 1 Mar. 2011). USDA Handb. No. 18. United States Government Printing Office, Washington, DC.

Soil Survey Staff, 1999. Soil Taxonomy. $2^{\text {nd }}$ ed. USDA Agric. United States Government Printing Office, Washington, DC.

Soukup, D.A., B.J. Buck, and W. Harris. 2008. Preparing soils for mineralogical analyses. p. 10-31. In Methods of Soil Analysis. Part 5. Mineralogical Methods. SSSA Book Series, no. 5. Madison, WI.

Tsai, Chen-Chi, Heng Tsai, Zeng-Yei Hseu, and Zueng-Sang Chen. 2007. Soil genesis along a chronosequence on marine terraces in eastern Taiwan. Catena 71:394-405.

Tsai, Wen-Shu Huang Heng, Chen-Chi Tsai, Zeng-Yei Hseu, and Zueng-Sang Chen. 2010. Subtropical soil chronosequence on Holocene marine terraces in eastern Taiwan. SSSA J. 74(4):1271-1283. 
Vepraskas, M.J. and M.A. Wilson. 2008. Soil micromorphology: Concepts, techniques, and applications. p. 191-225. In Methods of Soil Analysis. Part 5. Mineralogical Methods. SSSA Book Series, no. 5. Madison, WI.

Volk, G.M. 1937. Method of determination of the degree of dispersion of the clay fraction of soils. SSSA Proceedings 11:561-565.

Wagner, Stephen, Eduardo A.C. Costantin, Daniela Sauer, and Karl Stahr. 2007. Soil genesis in a marine terrace sequence of Sicily, Italy. Rev. Mexicana de Cienc. Geol. 24(2):247-260.

Wright, Robert J. and Tomasz Stuczynski. 1996. Atomic absorption and flame spectrometry. p. 65-90. In Methods of Soil Analysis. Part 3. Chemical Methods. SSSA Book Series, no. 5. Madison, WI. 
APPENDICES 
Appendix A: Table of Results for Regression Analyses 


\begin{tabular}{|c|c|c|c|c|c|c|c|c|c|c|c|c|c|c|c|c|}
\hline Depth & Depth & $\mathrm{Fe}_{\mathrm{d}}$ & $\mathrm{Fe}_{\mathrm{o}}$ & Nitrogen & Total Carbon & $\mathrm{pH}$ & EC & Sand & Silt & Clay & Quartz & Plagioclase & Mica & Shale & Unidentified or Fractured & Chert \\
\hline $\mathrm{m}$ & mean & $\mathrm{g} \mathrm{kg}^{-1}$ & $\mathrm{~g} \mathrm{~kg}^{-1}$ & $\%$ & $\%$ & & $\mathrm{mS} \mathrm{cm}^{-1}$ & $\%$ & $\%$ & $\%$ & $\%$ & $\%$ & $\%$ & $\%$ & $\%$ & $\%$ \\
\hline 10 to 11 & 10.5 & 1.16 & 0.22 & 0.006 & 0.020 & 5.4 & 0.01 & 100 & 0 & 0 & 86.60 & 0.00 & 2.18 & 10.59 & 0.00 & 0.62 \\
\hline 10 to 11 & 10.5 & 1.28 & 0.23 & 0.006 & 0.015 & 5.67 & 0.04 & 100 & 0 & 0 & 84.88 & 0.62 & 1.54 & 12.35 & 0.31 & 0.31 \\
\hline 10 to 11 & 10.5 & 1.22 & 0.15 & 0.008 & 0.019 & 5.61 & 0.07 & 100 & 0 & 0 & & & & & & \\
\hline 10 to 11 & 10.5 & 1.34 & 0.19 & 0.006 & 0.016 & 5.87 & 0.05 & 99 & 1 & 0 & & & & & & \\
\hline 10 to 11 & 10.5 & 1.69 & 0.19 & 0.007 & 0.023 & 6.17 & 0.00 & 97 & 2 & 1 & & & & & & \\
\hline 9 to 10 & 9.5 & 2.10 & 0.31 & 0.005 & 0.022 & 4.68 & 0.06 & 100 & 0 & 0 & 82.90 & 0.97 & 1.61 & 13.87 & 0.65 & 0.00 \\
\hline 9 to 10 & 9.5 & 2.16 & 0.28 & 0.013 & 0.015 & 4.74 & 0.00 & 100 & 0 & 0 & 82.16 & 0.58 & 2.63 & 9.94 & 4.09 & 0.58 \\
\hline 9 to 10 & 9.5 & 1.98 & 0.19 & 0.007 & 0.014 & 5.04 & 0.00 & 100 & 0 & 0 & & & & & & \\
\hline 9 to 10 & 9.5 & 2.74 & 0.54 & 0.011 & 0.031 & 6.08 & 0.31 & 95 & 3 & 2 & & & & & & \\
\hline 9 to 10 & 9.5 & 1.54 & 0.23 & 0.006 & 0.013 & 6.12 & 0.00 & 98 & 0 & 2 & & & & & & \\
\hline 8 to 9 & 8.5 & 2.34 & 0.32 & 0.003 & 0.021 & 6.8 & 0.00 & 100 & 0 & 0 & 91.75 & 0.00 & 1.27 & 5.40 & 1.59 & 0.00 \\
\hline 8 to 9 & 8.5 & 2.05 & 0.27 & 0.005 & 0.014 & 7.22 & 0.00 & 100 & 0 & 0 & 87.07 & 0.24 & 0.73 & 11.46 & 0.49 & 0.00 \\
\hline 8 to 9 & 8.5 & 2.02 & 0.29 & 0.006 & 0.012 & 7.5 & 0.00 & 100 & 0 & 0 & & & & & & \\
\hline 8 to 9 & 8.5 & 1.89 & 0.21 & 0.008 & 0.018 & 7.94 & 0.00 & 100 & 0 & 0 & & & & & & \\
\hline 8 to 9 & 8.5 & 2.21 & 0.27 & 0.007 & 0.014 & 8.22 & 0.00 & 100 & 0 & 0 & & & & & & \\
\hline 7 to 8 & 7.5 & 1.56 & 0.25 & 0.002 & 0.016 & 7.24 & 0.00 & 100 & 0 & 0 & 90.25 & 0.63 & 2.83 & 5.97 & 0.31 & 0.00 \\
\hline 7 to 8 & 7.5 & 2.14 & 0.25 & 0.006 & 0.013 & 7.34 & 0.00 & 100 & 0 & 0 & 87.08 & 0.62 & 2.15 & 9.23 & 0.92 & 0.00 \\
\hline 7 to 8 & 7.5 & 2.17 & 0.23 & 0.008 & 0.013 & 7.26 & 0.00 & 100 & 0 & 0 & & & & & & \\
\hline 7 to 8 & 7.5 & 1.99 & 0.21 & 0.007 & 0.014 & 7.31 & 0.00 & 99 & 1 & 0 & & & & & & \\
\hline 7 to 8 & 7.5 & 2.15 & 0.21 & 0.007 & 0.013 & 7.33 & 0.00 & 98 & 0 & 2 & & & & & & \\
\hline 6 to 7 & 6.5 & 0.33 & 0.30 & 0.001 & 0.016 & 7.67 & 0.00 & 100 & 0 & 0 & 87.70 & 0.95 & 2.21 & 8.20 & 0.95 & 0.00 \\
\hline 6 to 7 & 6.5 & 1.61 & 0.36 & 0.007 & 0.014 & 7.87 & 0.00 & 99 & 0 & 1 & 92.79 & 0.66 & 0.98 & 5.25 & 0.33 & 0.00 \\
\hline 6 to 7 & 6.5 & 2.14 & 0.43 & 0.008 & 0.015 & 7.29 & 0.00 & 97 & 0 & 3 & & & & & & \\
\hline 6 to 7 & 6.5 & 2.04 & 0.32 & 0.007 & 0.015 & 7.3 & 0.05 & 95 & 0 & 5 & & & & & & \\
\hline 6 to 7 & 6.5 & 2.25 & 0.32 & 0.007 & 0.014 & 8.12 & 0.00 & 97 & 0 & 3 & & & & & & \\
\hline 2 to 3 & 2.5 & 2.80 & 0.65 & 0.006 & 0.099 & 6.7 & 0.00 & 99 & 1 & 0 & 86.25 & 0.94 & 1.56 & 10.63 & 0.63 & 0.00 \\
\hline 2 to 3 & 2.5 & 2.71 & 0.75 & 0.012 & 0.095 & 7.13 & 0.00 & 99 & 1 & 0 & 83.55 & 0.97 & 5.81 & 9.35 & 0.00 & 0.32 \\
\hline 2 to 3 & 2.5 & 2.73 & 0.65 & 0.011 & 0.079 & 6.79 & 0.00 & 99 & 0 & 1 & & & & & & \\
\hline 2 to 3 & 2.5 & 2.54 & 0.70 & 0.013 & 0.109 & 6.69 & 0.01 & 97 & 2 & 1 & & & & & & \\
\hline 2 to 3 & 2.5 & 2.64 & 0.73 & 0.013 & 0.093 & 7.19 & 0.00 & 97 & 0 & 3 & & & & & & \\
\hline 1 to 2 & 1.5 & 2.01 & 0.43 & 0.005 & 0.082 & 5.98 & 0.07 & 100 & 0 & 0 & 86.32 & 0.61 & 4.26 & 7.90 & 0.30 & 0.61 \\
\hline 1 to 2 & 1.5 & 2.34 & 0.61 & 0.009 & 0.060 & 6.5 & 0.00 & 97 & 1 & 2 & 87.01 & 0.00 & 1.69 & 11.30 & 0.00 & 0.00 \\
\hline 1 to 2 & 1.5 & 2.28 & 0.52 & 0.012 & 0.100 & 5.88 & 0.07 & 95 & 1 & 4 & & & & & & \\
\hline 1 to 2 & 1.5 & 2.24 & 0.47 & 0.010 & 0.065 & 6.06 & 0.09 & 96 & 2 & 2 & & & & & & \\
\hline 1 to 2 & 1.5 & 2.41 & 0.55 & 0.013 & 0.078 & 6.32 & 0.02 & 96 & 2 & 2 & & & & & & \\
\hline 0 to 1 & 0.5 & 2.74 & 0.76 & 0.039 & 0.580 & 5.71 & 0.03 & 97 & 1 & 2 & 84.08 & 0.64 & 1.27 & 13.69 & 0.32 & 0.00 \\
\hline
\end{tabular}




\begin{tabular}{|c|c|c|c|c|c|c|c|c|c|c|c|c|c|c|c|c|}
\hline Depth & Depth & $\mathrm{Fe}_{\mathrm{d}}$ & $\mathrm{Fe}_{\mathrm{o}}$ & Nitrogen & Total Carbon & $\mathrm{pH}$ & EC & Sand & Silt & Clay & Quartz & Plagioclase & Mica & Shale & Unidentified or Fractured & Chert \\
\hline $\mathrm{m}$ & mean & $\mathrm{g} \mathrm{kg}^{-1}$ & $\mathrm{~g} \mathrm{~kg}^{-1}$ & $\%$ & $\%$ & & $\mathrm{mS} \mathrm{cm}^{-1}$ & $\%$ & $\%$ & $\%$ & $\%$ & $\%$ & $\%$ & $\%$ & $\%$ & $\%$ \\
\hline 0 to 1 & 0.5 & 2.65 & 0.79 & 0.041 & 0.596 & 5.4 & 0.15 & 98 & 0 & 2 & & & & & & \\
\hline 0 to 1 & 0.5 & 2.30 & 0.64 & 0.047 & 0.546 & 5.75 & 0.00 & 98 & 0 & 2 & & & & & & \\
\hline 0 to 1 & 0.5 & 2.58 & 0.77 & 0.036 & 0.422 & 6.05 & 0.00 & 97 & 1 & 2 & & & & & & \\
\hline 0 to 1 & 0.5 & 2.27 & 0.58 & 0.021 & 0.135 & 5.04 & 0.30 & 96 & 1 & 3 & & & & & & \\
\hline 5 to 6 & 5.5 & 0.87 & 5.50 & 0.002 & 0.044 & 6.02 & 0.31 & 96 & 0 & 4 & & & & & & \\
\hline 5 to 6 & 5.5 & 0.57 & 5.50 & 0.007 & 0.042 & 6.3 & 0.07 & 100 & 0 & 0 & & & & & & \\
\hline 5 to 6 & 5.5 & 0.69 & 5.50 & 0.007 & 0.042 & 6.28 & 0.00 & 96 & 0 & 4 & & & & & & \\
\hline 5 to 6 & 5.5 & 0.59 & 5.50 & 0.006 & 0.031 & 6.41 & 0.08 & 98 & 0 & 2 & & & & & & \\
\hline 5 to 6 & 5.5 & 0.59 & 5.50 & 0.007 & 0.038 & 6.41 & 0.40 & 97 & 0 & 3 & & & & & & \\
\hline
\end{tabular}


Appendix B: Plates of Thin Section Features 


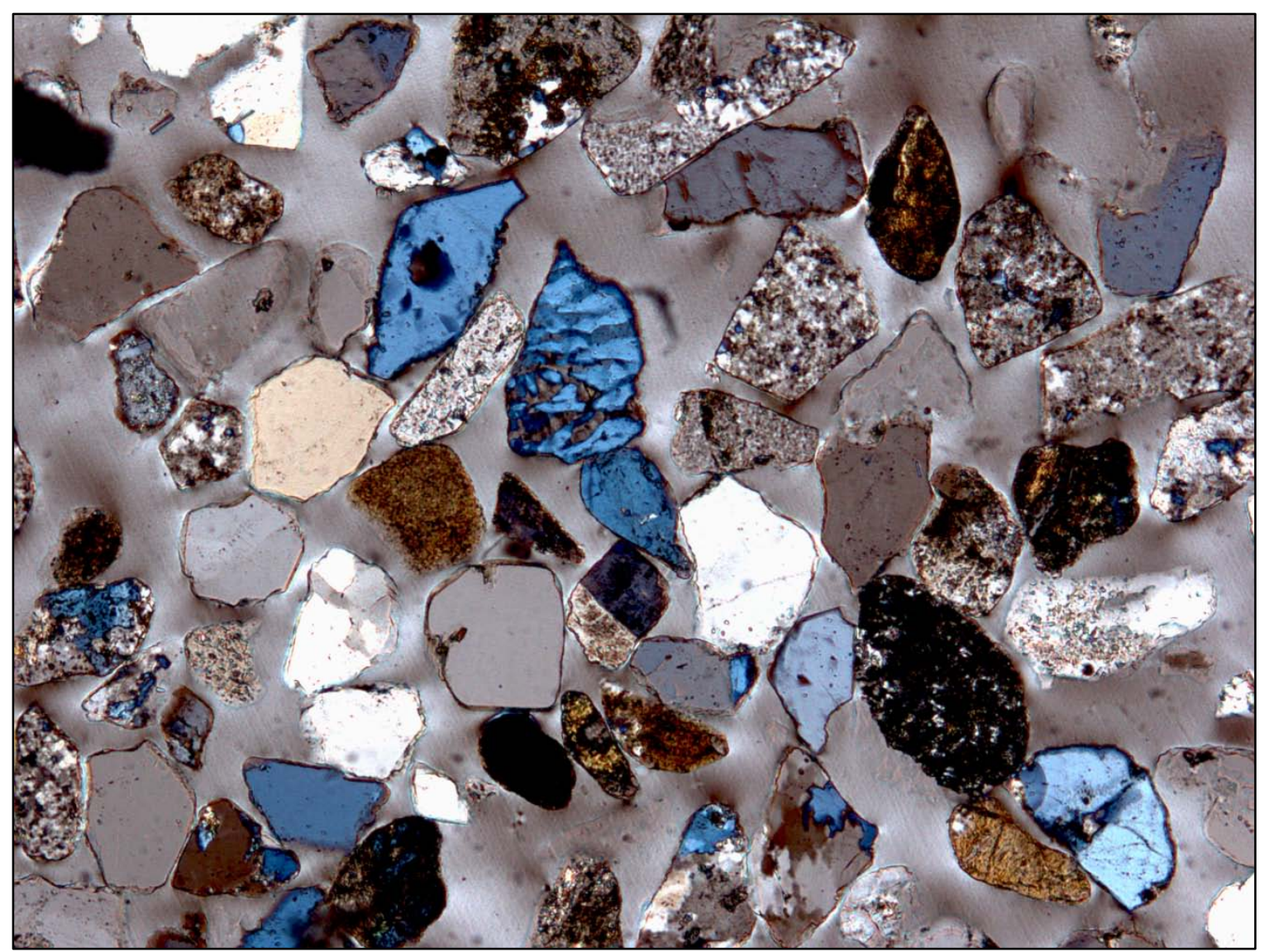

Plate I. Assorted minerals located 10 to 11 meters depth under cross-polars at $40 \mathrm{X}$ magnification (Photomicrograph credits: Lyssa A. Cousineau and Adrian Gallo). The blue-tinted and grey to white minerals with few inclusions are quartz; the salt and pepper grains are chert; the reddish-tinted grains are shale. 


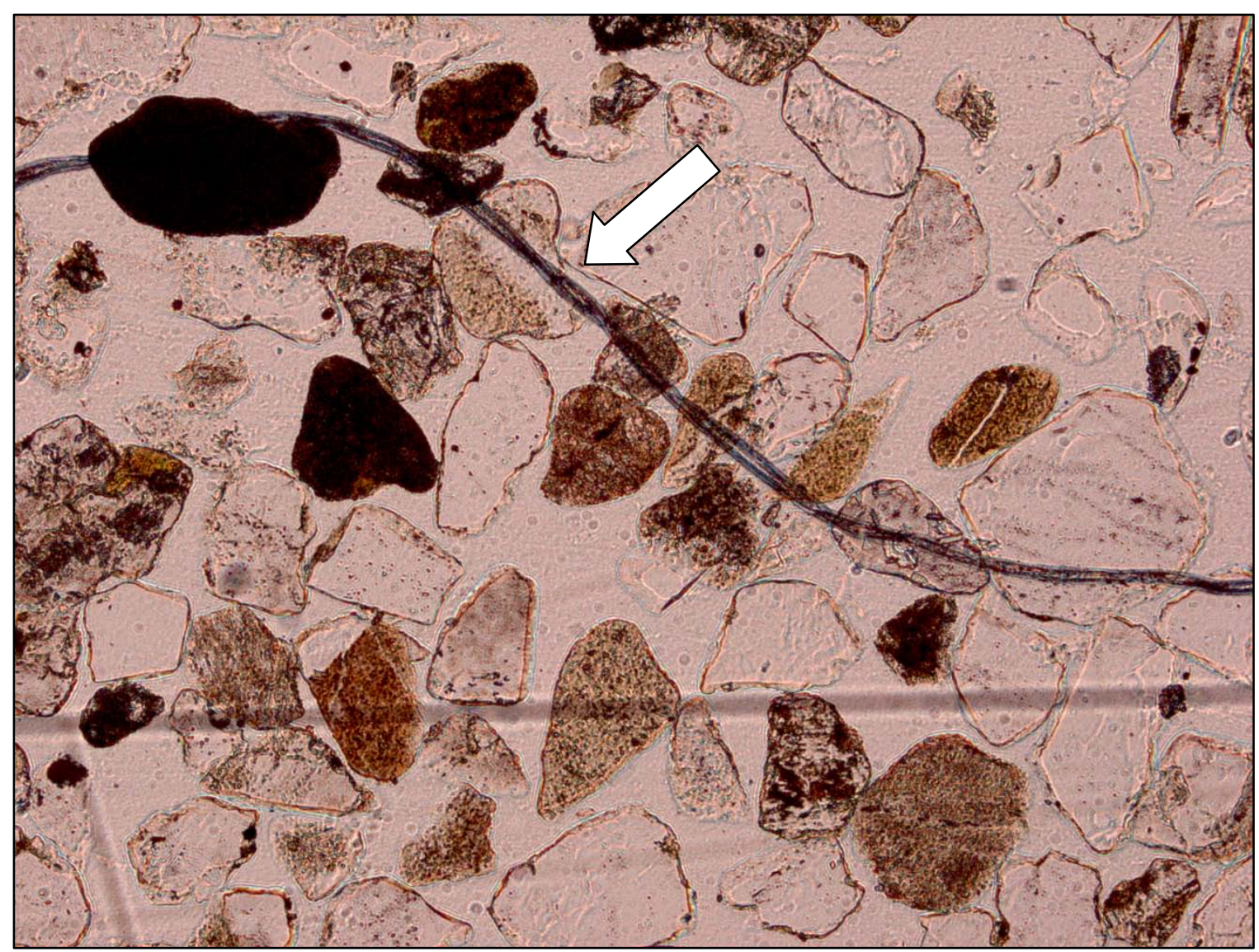

Plate II. Modern root vertically positioned and located 10 to 11 meters depth under plane polarized light at 40X magnification (Photomicrograph credits: Lyssa A. Cousineau and Adrian Gallo). Root has leached Fe-staining from quartz grain in the upper left-hand quadrant of the photo (see arrow). 


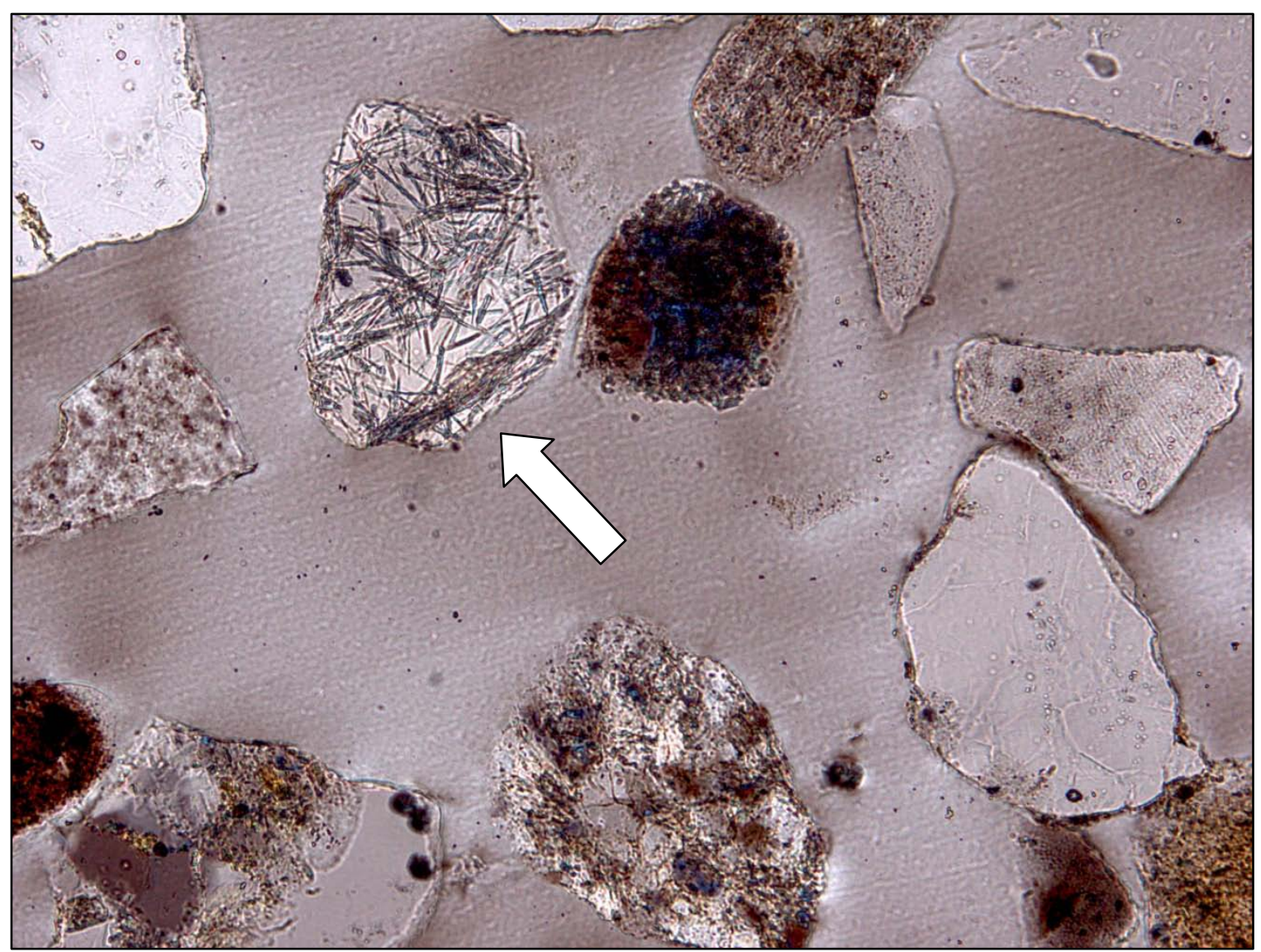

Plate III. Rutilated quartz in upper left-hand quadrant of photo under cross-polars located 10 to 11 meters depth at $100 \mathrm{X}$ magnification (Photomicrograph credits: Lyssa A. Cousineau and Adrian Gallo). Rutilated quartz was captured a few times in various thin sections. 


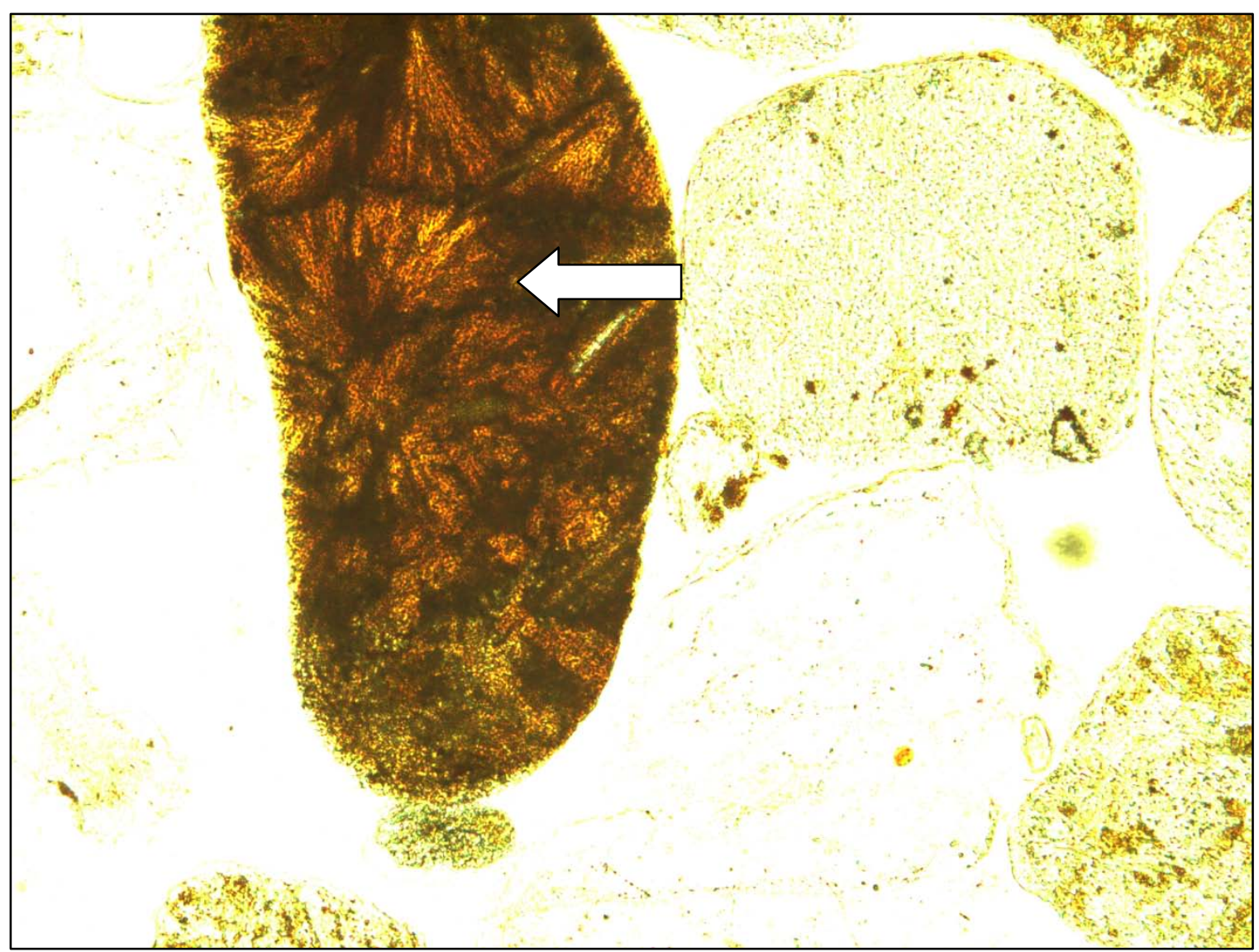

Plate IV. Spherical, radiating structures in shale fragment located 9 to 10 meters depth under plane polarized light at 100X magnification (Photomicrograph credits: Lyssa A. Cousineau and Adrian Gallo). 


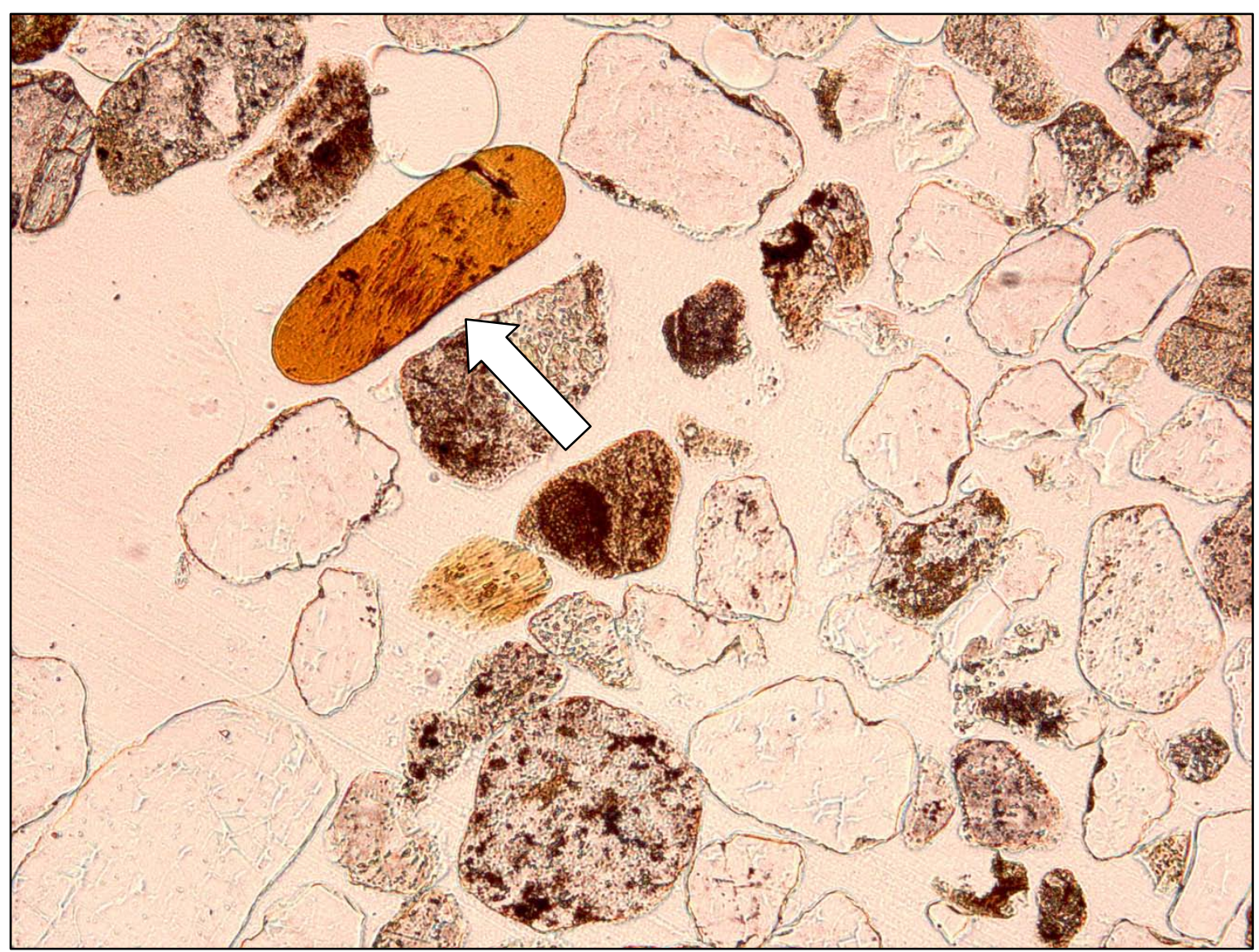

Plate V. Prominently orange-tinted grain of shale located 9 to 10 meters depth under plane polarized light at 40X magnification (Photomicrograph credits: Lyssa A. Cousineau and Adrian Gallo). 


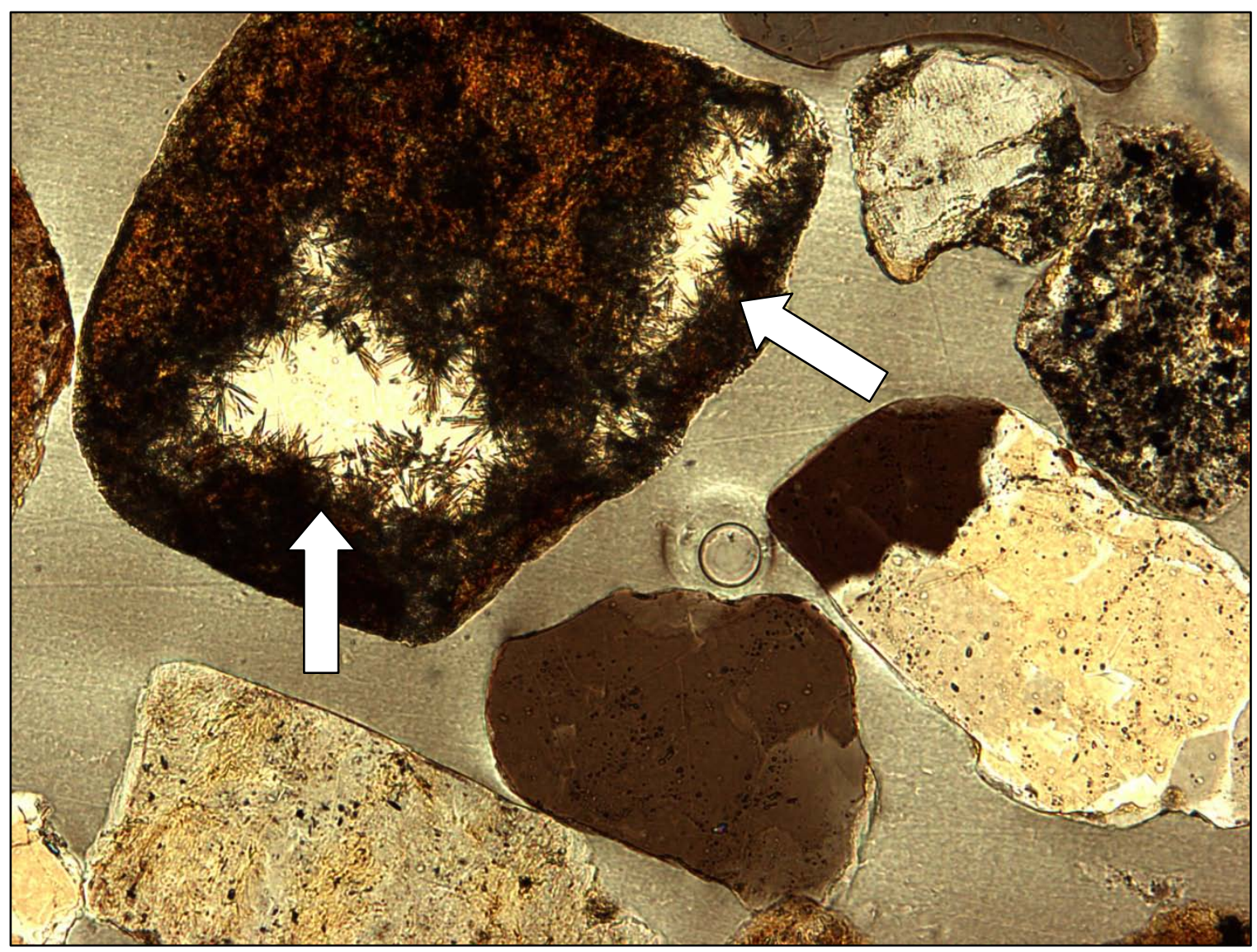

Plate VI. Rutilated quartz development located 9 to 10 meters depth at 100X magnification under plane polarized light (Photomicrograph credits: Lyssa A. Cousineau and Adrian Gallo). 


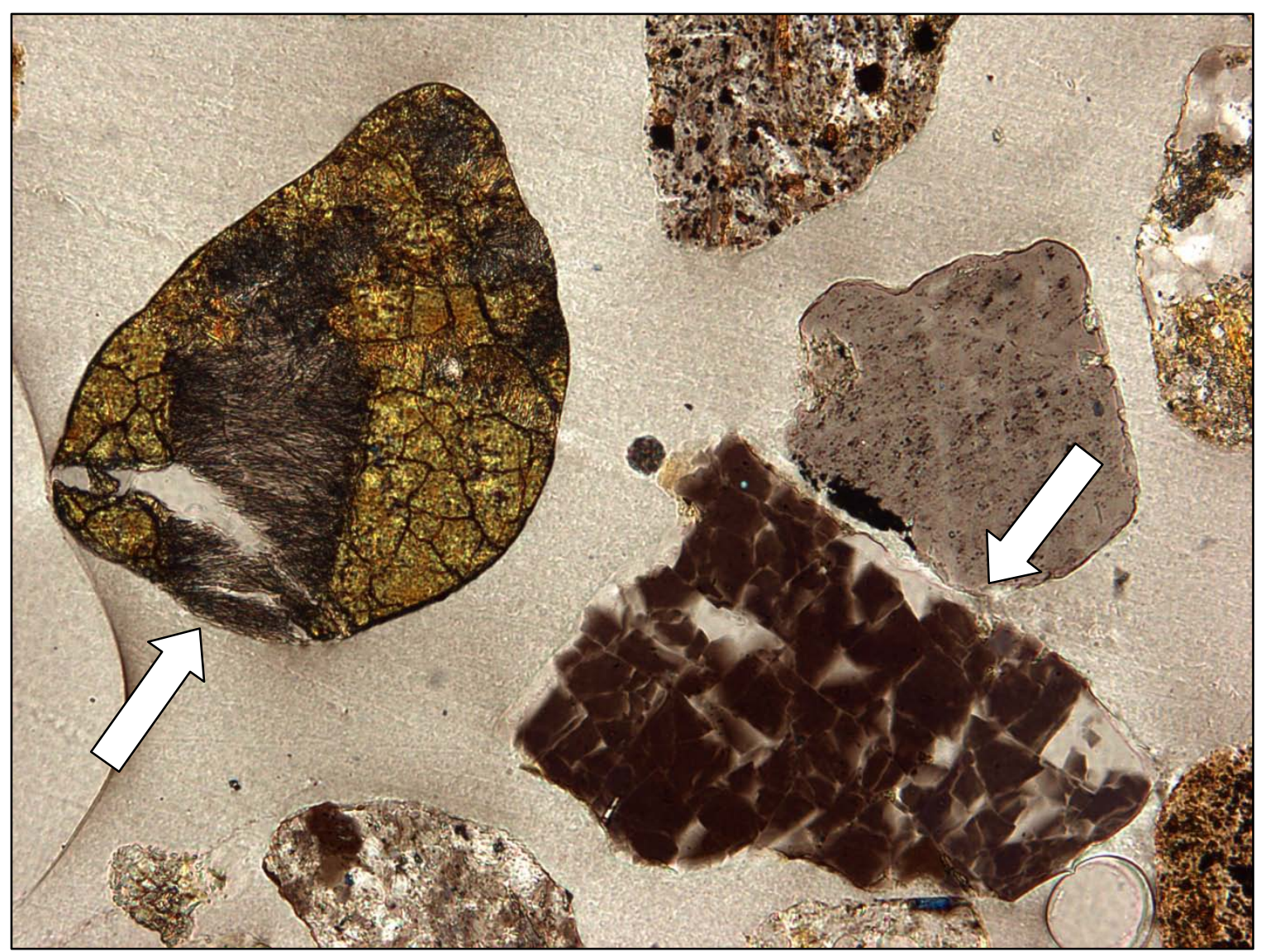

Plate VII. Grain to the left is a fragment of serpentinite with fibers of chrysotile located 9 to 10 meters depth at $100 \mathrm{X}$ magnification under plane polarized light (Photomicrograph credits: Lyssa A. Cousineau and Adrian Gallo). Grain to the right is highly weathered feldspar. 


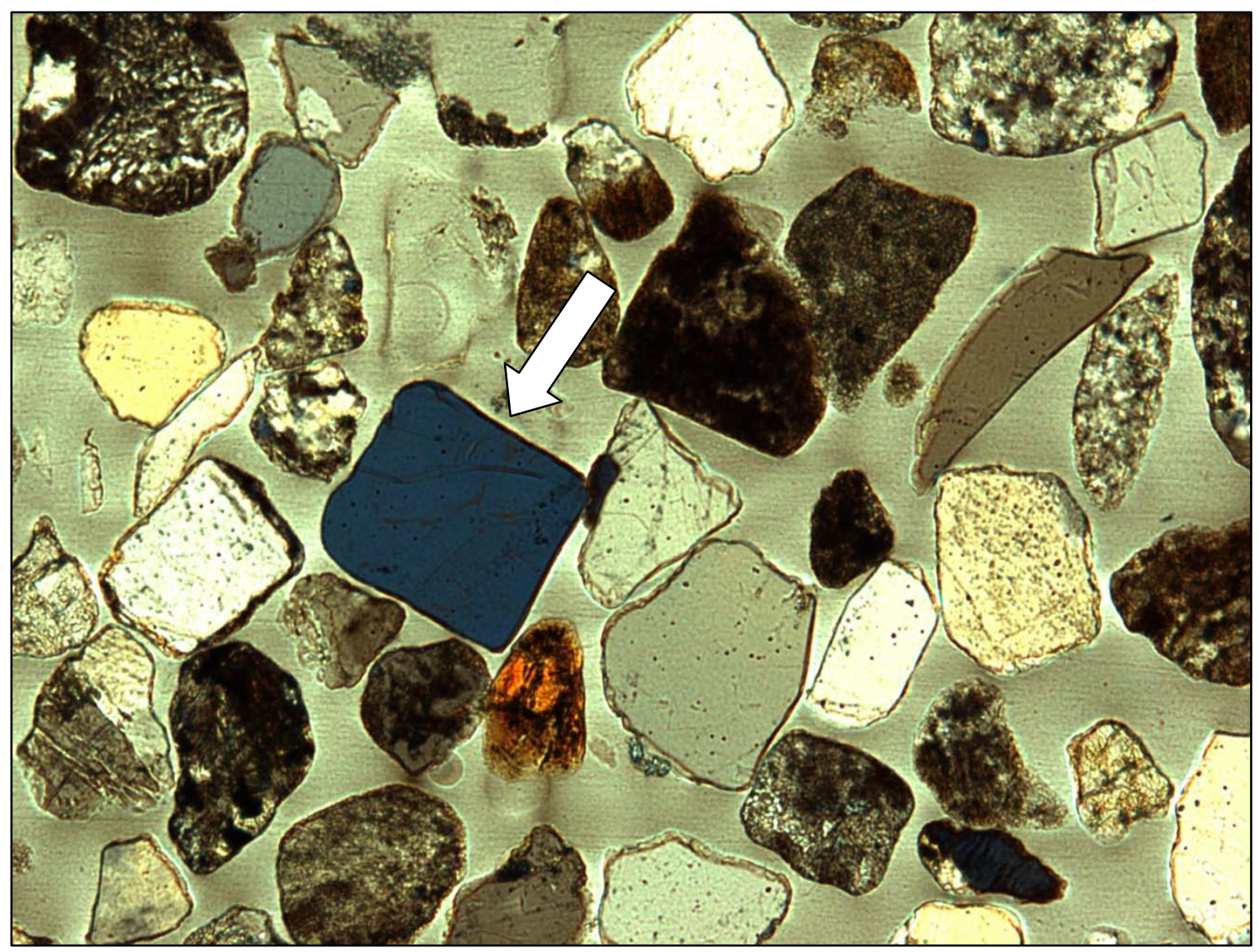

Plate VIII. Square-shaped quartz grain under cross-polars located 7 to 8 meters depth at 40X magnification (Photomicrograph credits: Lyssa A. Cousineau and Adrian Gallo). 


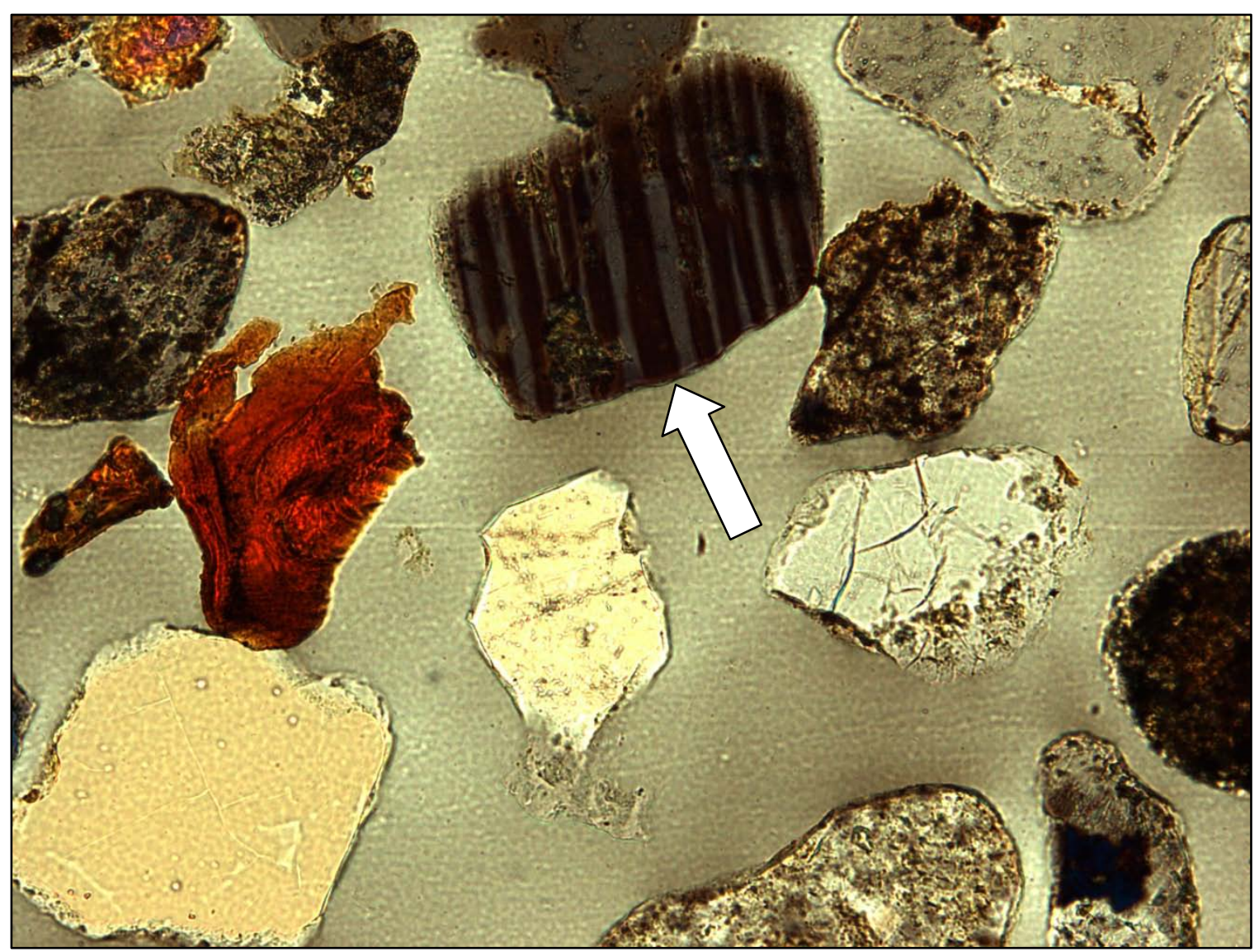

Plate IX. Twinned plagioclase grain under cross-polars located 7 to 8 meters depth at 100X magnification (Photomicrograph credits: Lyssa A. Cousineau and Adrian Gallo). 


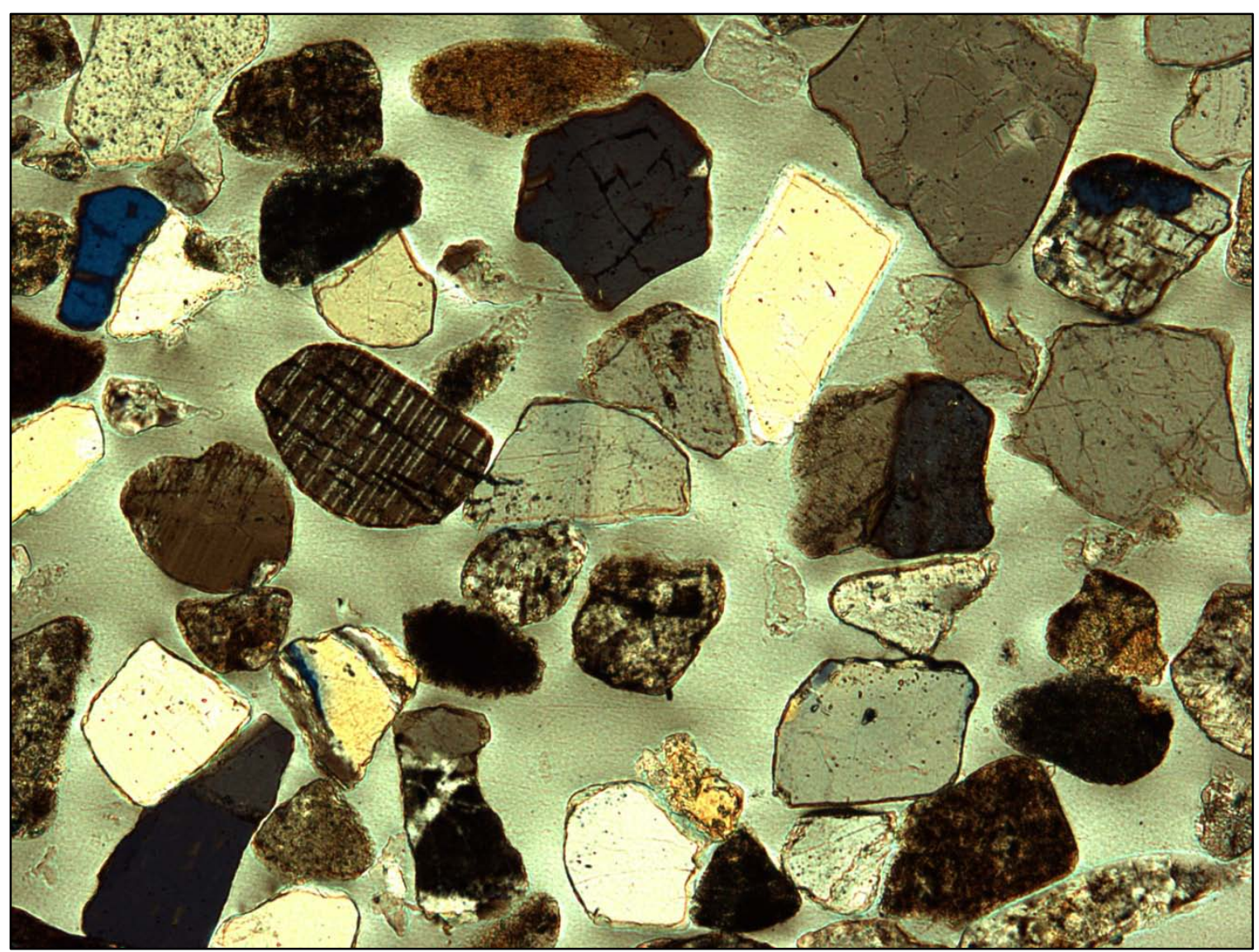

Plate X. Twinned and fractured plagioclase grain under cross-polars located 6 to 7 meters depth at 40X magnification (Photomicrograph credits: Lyssa A. Cousineau and Adrian Gallo). 


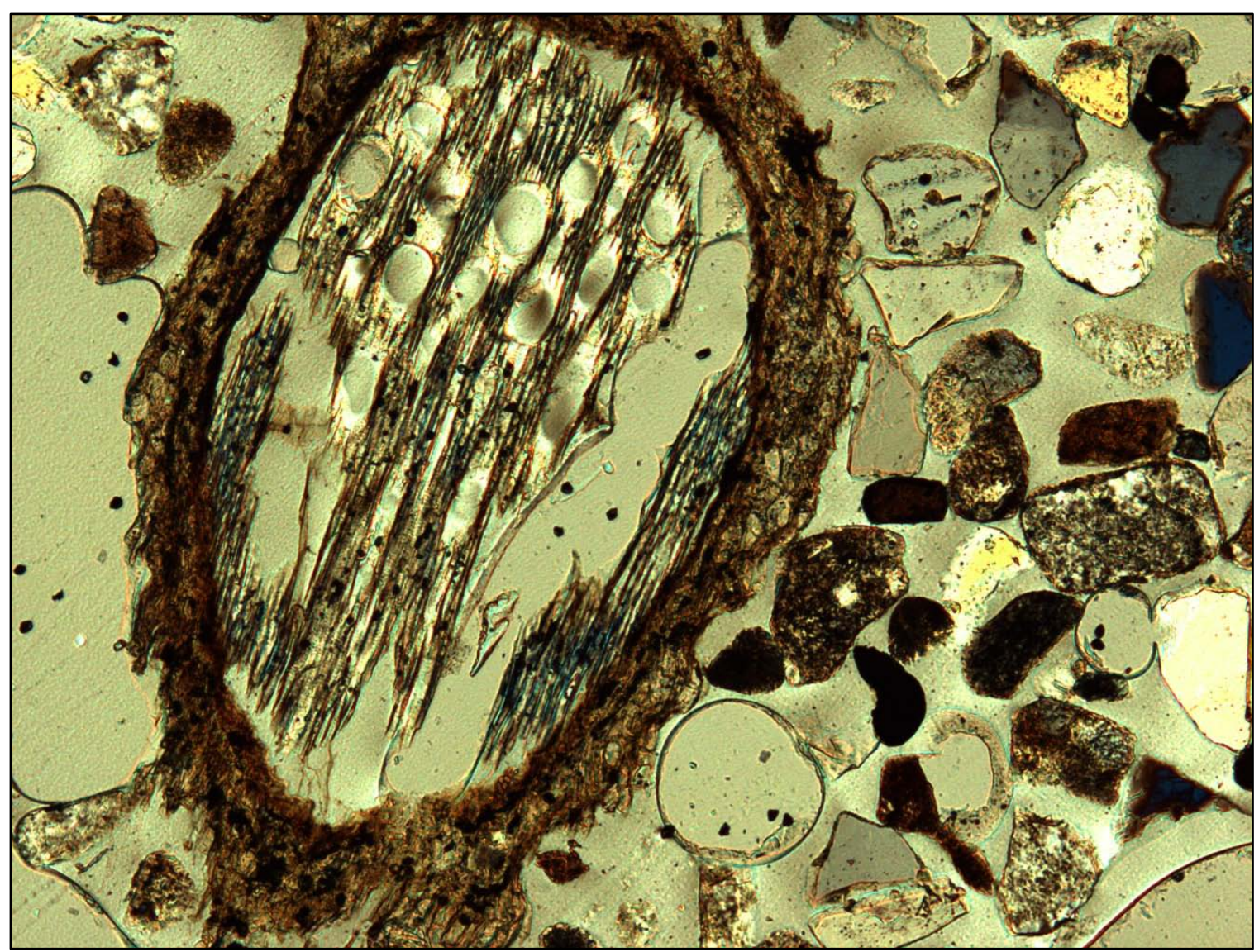

Plate XI. Cross section of modern root located 1 to 2 meters depth at 40X magnification under plane polarized light (Photomicrograph credits: Lyssa A. Cousineau and Adrian Gallo). 


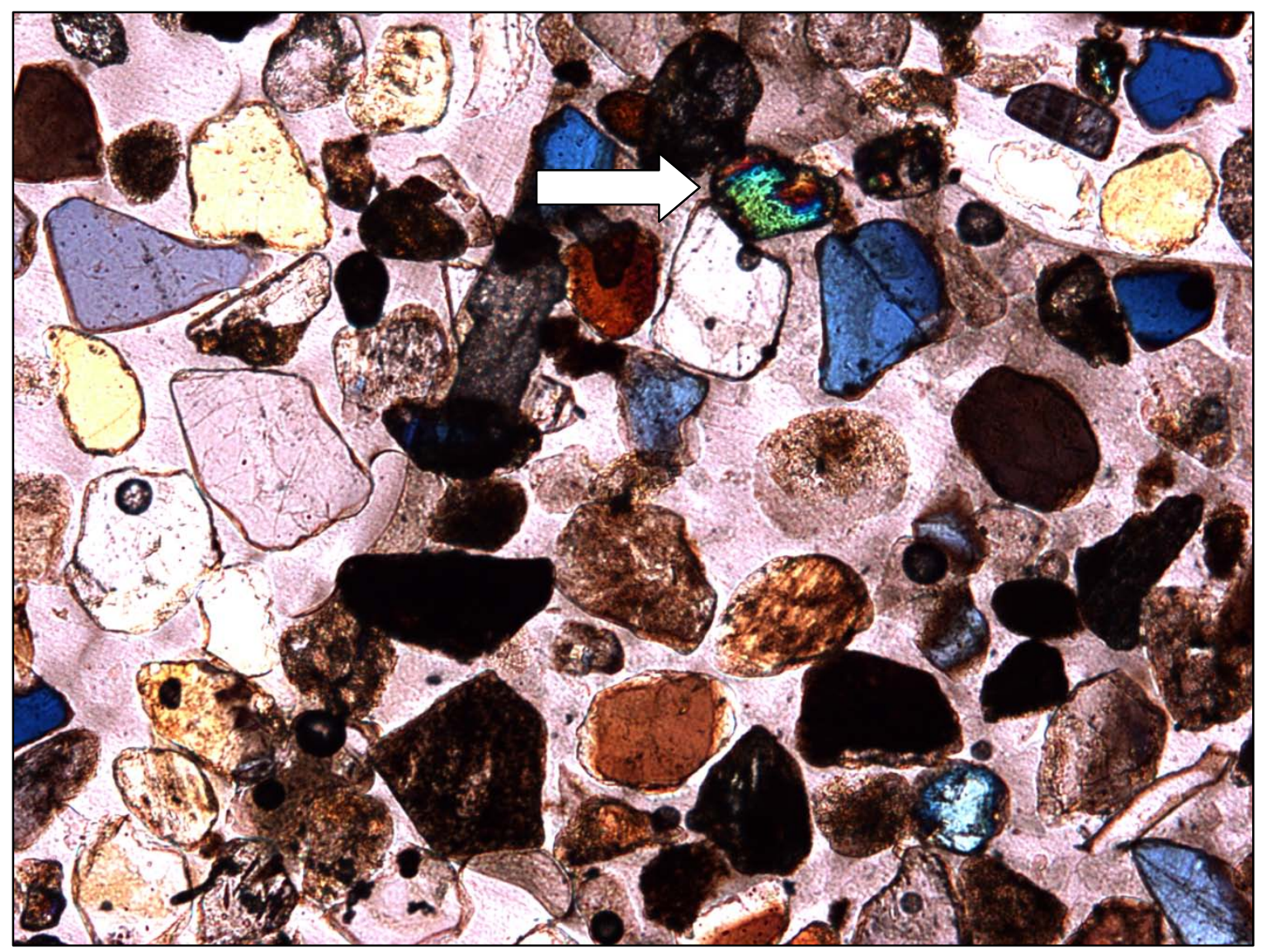

Plate XII. Bright green-blue mica grain (due to third order birefringence) under crosspolars located 1 to 2 meters depth at 40X magnification (Photomicrograph credits: Lyssa A. Cousineau and Adrian Gallo). 


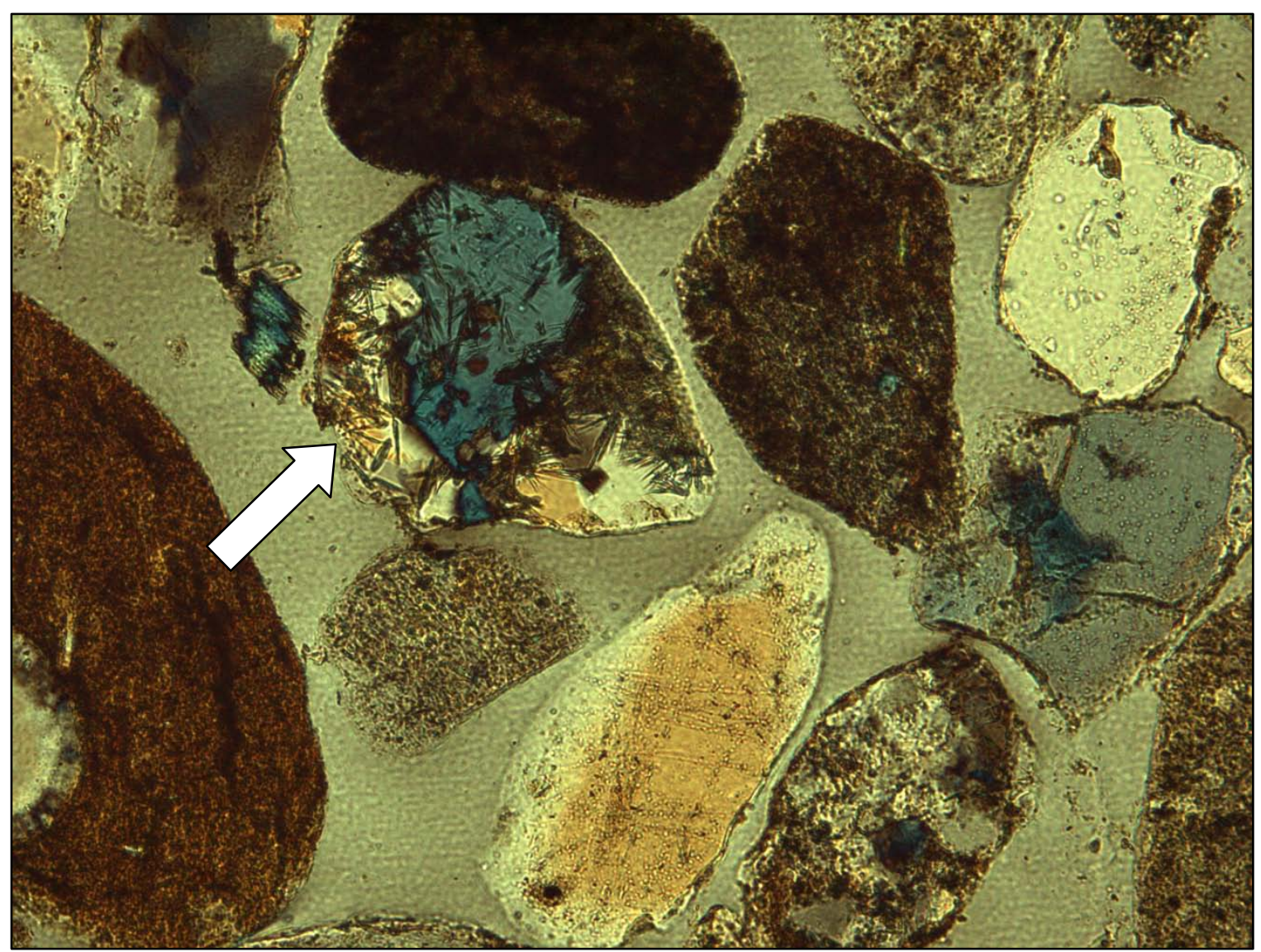

Plate XIII. Rutilated quartz grain under cross-polars located 0 to 1 meters depth at 100X magnification (Photomicrograph credits: Lyssa A. Cousineau and Adrian Gallo). 


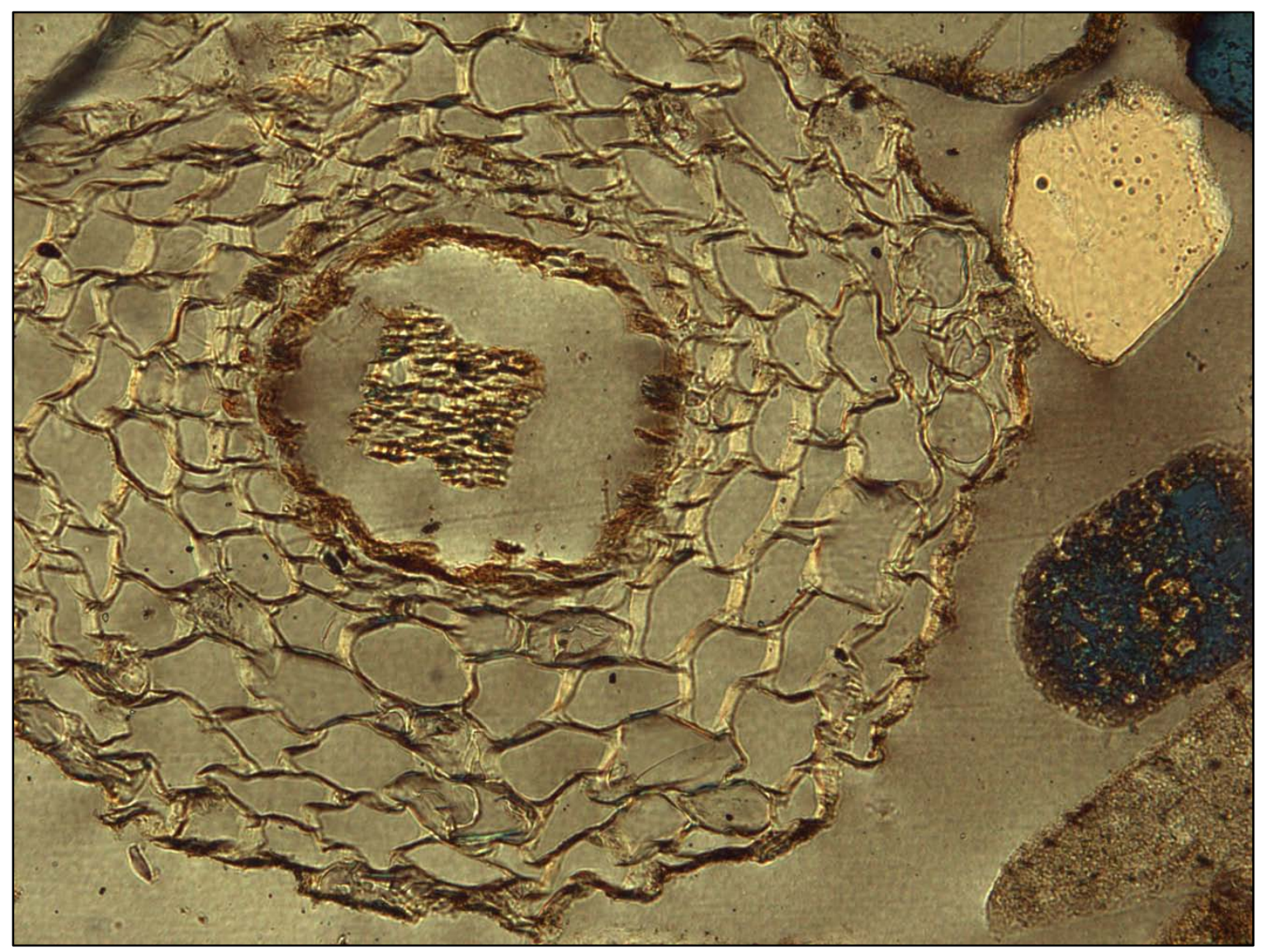

Plate XIV. Close-up of cross section of root covered by mycorrhizal sheath (Figure 3-9) located 0 to 1 meters depth at 100X magnification under plane polarized light (Photomicrograph credits: Lyssa A. Cousineau and Adrian Gallo). 


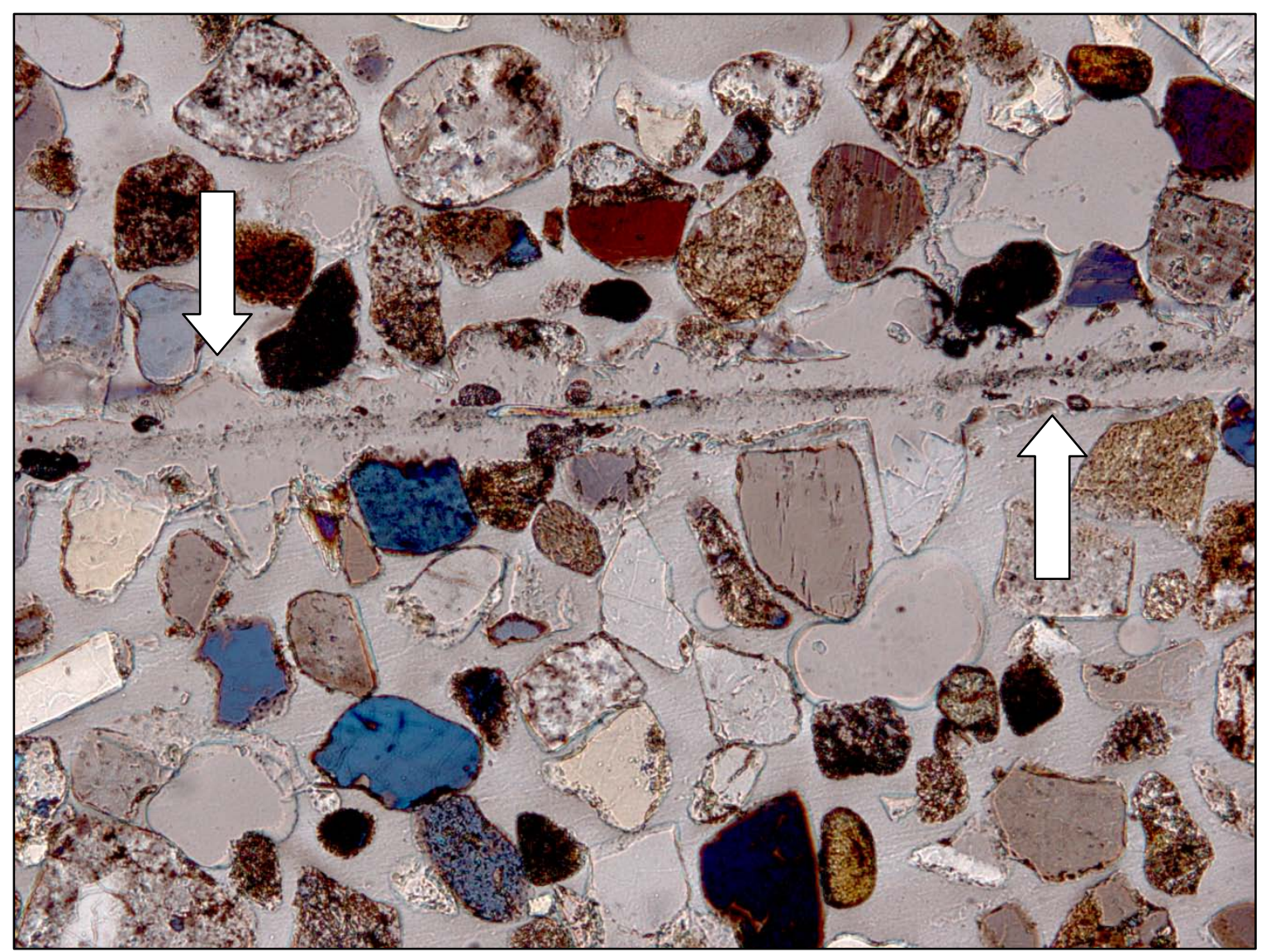

Plate XV. Cross section of modern root channel (between arrows) under cross-polars located 0 to 1 meters depth at 40X magnification (Photomicrograph credits: Lyssa A. Cousineau and Adrian Gallo). Root channel measures about $1 \mathrm{~cm}$ in length. 